\title{
Problems of Proof in Conscientious Objector Cases
}

\section{Citation}

Martha A. Field, Problems of Proof in Conscientious Objector Cases, 120 U. Pa. L. Rev. 870 (1972).

\section{Published Version}

http://scholarship.law.upenn.edu/penn_law_review/vol120/iss5/2/

\section{Permanent link}

http://nrs.harvard.edu/urn-3:HUL.InstRepos:12991695

\section{Terms of Use}

This article was downloaded from Harvard University's DASH repository, and is made available under the terms and conditions applicable to Other Posted Material, as set forth at http:// nrs.harvard.edu/urn-3:HUL.InstRepos:dash.current.terms-of-use\#LAA

\section{Share Your Story}

The Harvard community has made this article openly available.

Please share how this access benefits you. Submit a story.

Accessibility 


\title{
PROBLEMS OF PROOF IN CONSCIENTIOUS OBJECTOR CASES
}

\author{
Martha A. Fietd $\dagger$
}

On September 28, 1971, Congress extended the draft for two years ${ }^{1}$ and made a number of changes in the Military Selective Service Act of $1967 .^{2}$ Although provisions relating specifically to conscientious objectors were largely unaltered, ${ }^{3}$ procedural rights granted all registrants will have an effect on the problems of proof and factfinding that have long vexed the determination of conscientious objector claims. The most important of these procedural reforms is a requirement that

[i]n the event of a decision adverse to the claim of a registrant, the local or appeal board making such decision shall, upon request, furnish to such registrant a brief written statement of the reasons for its decision. ${ }^{4}$

$\dagger$ Assistant Professor of Law, University of Pennsylvania. A.B. 1965, Radcliffe; J.D. 1968, University of Chicago. Member, District of Columbia Bar.

1 Act of Sept. 28, 1971, Pub. L. No. 92-129, tit. I, \$101 (a) (35), 85 Stat. 353, annending Military Selective Service Act of 1967 \$17(c), 50 U.S.C. ApP. \&467(c) (1970) (codified at 50 U.S.C.A. APP. $\$ 467$ (c) (Supp. 1972)). The amendments also changed the name of the 1967 Act to the Military Selective Service Act. 50 U.S.C.A. APP. $\$ 451$ (a) (Supp. 1972), annending Military Selective Service Act of 1967 \$1(a), 50 U.S.C. APP. $\$ 451$ (a) (1970).

2 Act of Sept. 28, 1971, Pub. L. No. 92-129, tit. I, §101(a), 85 Stat. 348-55, annending Military Selective Service Act of $1967 \$ \$ 1-23,50$ U.S.C. APP. $\$ \$ 451-73$ (1970) (codified at 50 U.S.C.A. APP. $\$ \$ 451-73$ (Supp. 1972)). The Act also amended other aspects of federal law related to the military.

3 The only statutory change relating specifically to conscientious objectors transfers responsibility for administering the civilian work program from local draft boards to the National Headquarters of the Selective Service System. 50 U.S.C.A. APr. $\$ 456(\mathrm{j})$ (Supp, 1972), amending Military Selective Service Act of $1967 \S 6(\mathrm{j}), 50$ U.S.C. APP. \$ 456(j) (1970). A recent regulation requires, however, that the State Director, "under the supervision of" the National Director administer the alternative service program. 32 C.F.R. \$1660.1(a) (1972). The duties of the State Director with respect to the alternative service program are more specifically enumerated at id. $\$ \$ 1660.1(\mathrm{~b})-(\mathrm{c})$. These provisions are set forth in note 10 infra.

The Military Selective Service Act grants plenary rulemaking power to the President, 50 U.S.C. App. $\$ 460$ (b) (1) (1970), and allows the President to delegate and provide for the subdelegation of his authority. Id. $\$ 460$ (c). The Act also creates the Selective Service System and provides that it shall be headed by a Director. Id. $\$ 460$ (a) (1). By regulation, the President has granted the Director power

[t]o prescribe such rules and regulations as he shall deem necessary for

the administration of the Selective Service System, the conduct of its officers and employees, the distribution and performance of its business, and the custody, use, and preservation of its records, papers, and property.

32 C.F.R. \$1604.1 (a) (1972). By executive order, the President has granted the Director authority to make draft regulations. Exec. Order No. 11,623, \&1, 3 C.F.R. 211 (1972). The President retained authority to issue rules himself. Id. $\S 3$.

4 Military Selective Service Act $\$ 22$ (b) (4), 50 U.S.C.A. APP. $\$ 471 a(b)$ (4) (Supp. 1972), amending 50 U.S.C. APP. \$451(a)'(1970). 
This Article will examine the statutory and procedural framework within which a claim of conscientious objection must be asserted and will consider various obstacles to reliable factfinding. It will then focus on the newly-adopted requirement that draft boards reveal their bases of decision and will evaluate the impact of that requirement on the operation of the system. Finally, it will suggest a new approach to dealing with conscientious objector claims.

\section{Administrative and Judicial Procedure}

\section{A. Selective Service Procedures}

Section 6(j) of the Military Selective Service Act of 1967 exempts from combatant service any person "who, by reason of religious training and belief, is conscientiously opposed to participation in war in any form." s Church training or membership is not required; the Supreme Court has held that a person's objection is sufficiently "religious" if it "stem[s] from the registrant's moral, ethical, or religious beliefs about what is right and wrong and . . . these beliefs [are] held with the strength of traditional religious convictions." 6 Total op-

550 U.S.C. ApP. $\$ 456(j)$ (1970), as amended, 50 U.S.C.A. ApP. \$456(j) (Supp. 1972). The section provides:

Nothing contained in this title. . . shall be construed to require any person to be subject to combatant training and service in the armed forces of the United States who, by reason of religious training and belief, is conscientiously opposed to participation in war in any form. As used in this subsection, the term "religious training and belief" does not include essentially political sociological or philosophical views, or a merely personal moral code. Any person claiming exemption from combatant training and service because of such conscientious objections whose claim is sustained by the local board shall, if he is inducted into the armed forces under this title . . . be assigned to noncombatant service as defined by the President, or shail, if he is found to be conscientiously opposed to participation in such noncombatant service, in lieu of such induction, be ordered by his local board, subject to such regulations as the President may prescribe, to perform for a period equal to the period prescribed in section 4(b) [24 months] such civilian work contributing to the maintenance of the national health, safety, or interest ... and any such person who knowingly fails or neglects to obey any such order from his local board shall be deemed, for the purposes of section 12 of this title ... to have knowingly failed or neglected to perform a duty required of him under this title...

6 Welsh v. United States, 398 U.S. 333, 340 (1970) (opinion of Black, J.). The Court so held despite the statutory provision limiting the meaning of "religious training and belief." See note 5 supra. It held also that the only persons excluded are "those whose beliefs are not deeply held and those whose objection to war does not rest at all upon moral, ethical, or religious principle but instead rests solely upon considerations of policy, pragmatism, or expediency." Id. at 342-43. The statutory construction that led to this result will be explored more extensively. See text accompanying notes 112-33 infra.

Although Mr. Justice Black's opinion announcing the judgment of the Court was joined by only three other Justices, the test it adopts for conscientious objection was concurred in by a majority of the Court. Mr. Justice Harlan did not accept the conclusion that the test adopted could be arrived at as a matter of statutory construction, but he considered the statute unconstitutional and adopted the same test as Mr. Justice Black "not as a reflection of congressional statutory intent but as patchwork of judicial making that cures the defect of under-inclusion in $\S 6(j)$...." 398 U.S. at 366-67 (concurring opinion). 
position to the use of force in any and all circumstances is not necessary; one's objection need only extend to "war in any form." 7

A person meeting this test for conscientious objection may be classified I-A-O ${ }^{8}$ and, if inducted, he will be assigned to service that does not require killing or bearing arms. Typically, I-A-O's serve as medics, though they may work in other noncombatant jobs as, for example, cooks or truck drivers. ${ }^{9}$ If, however, a man's conscientious objection extends also to noncombatant service he will be classified I-O and exempted from all military service. ${ }^{10}$ Instead of military service, the I-O registrant who would otherwise be inducted is required to perform "such civilian work contributing to the maintenance of the national health, safety, or interest as the [National] Director may deem appropriate ...."11 The registrant performing alternate civilian

7 Gillette v. United States, 401 U.S. 437, 447-48 (1971) (emphasis added); Sicurella v. United States, 348 U.S. $385,389-90$ (1955); see United States v. Haughton, 413 F.2d 736, 740-42 (9th Cir. 1969); United States v. Carroll, 398 F.2d 651,655 (3d Cir. 1968). In practice, however, a registrant who does claim total nonviolence may have less difficulty getting his claim sustained. Reisner, Selective Service Appeal Boards and the Conscientious Objector Clainant: Congressional Standards and Administrative Behavior, 1971 WIS. L. REv. 521, 537.

$8 \mathrm{By}$ regulation, each registrant is classified in one of several enumerated classes. 32 C.F.R. \$\$1622.1-.2 (1972). Classification I-A-O includes

every registrant who would have been classified in Class I-A but for the fact that he has been found, by reason of religious, ethical, or moral belief, to be conscientiously opposed to participation in combatant training and service in the armed forces.

37 Fed. Reg. 5121 (1972) (to be codified at 32 C.F.R. $\$ 1622.11$ ).

9 An executive order defines noncombatant training as "any training which is not concerned with the study, use, or handling of arms or weapons" and noncombatant service as:

(a) service in any unit ... which is unarmed at all times; (b) service in the medical department of any of the armed forces, wherever performed; or (c) any other assignment the primary function of which does not require the use of arms in combat; provided that such other assignment is acceptable to the individual concerned and does not require him to bear arms or to be trained in their use.

Exec. Order No. 10,028, 14 Fed. Reg. 211 (1949), 50 U.S.C. APp. $\$ 456$ (1970).

1037 Fed. Reg. 5121 (1972) (to be codified at 32 C.F.R. $\$ 1622.14$ ).

1150 U.S.C.A. ApP. $\$ 456(\mathrm{j})$ (Supp. 1972), amending 50 U.S.C. APP. § 456(j) (1970). New regulations, in addition to generally subdelegating the National Director's authority to administer the civilian work program to the State Director, see note 3 supra, provide that "[t]he State director of the State in which a registrant is registered will have primary responsibility for the initial placement of the registrant in alternate service." 32 C.F.R. \$ 1660.1 (b) (1972).

The registrant is able to play an active role in selecting his job assignment. He may submit proposed jobs to the State Director. If a proposed job is approved, a work order is issued. 37 Fed. Reg. 5127 (1972) (to be codified at 32 C.F.R. $\S \S 1660.3, .7(\mathrm{~b}))$. If the job is not approved, the registrant may seek review of that decision. 32 C.F.R. $\$ 1660.7$ (e) (1972). The I-O registrant may accept a job anticipating that it will be approved as alternate service. If he is correct, he will receive credit for the time he has worked (but only time after he was classified I-O) prior to approval. Id. $\$ 1660.7$ (d). Only if a registrant has (a) taken a job that is subsequently disapproved; or (b) not submitted any approved jobs to the State Director within 60 days from the time he was classified I-O will he be ordered to take a specific alternate service job. $I d$. $\$ \$ 1660.7(\mathrm{c})$, (e).

Government jobs and jobs with charitable or nonprofit organizations that are primarily for the benefit of the public, $i d$. $\$ 1660.5$, are among those that qualify for 
service is paid by the employer at the going rate for his job. ${ }^{12}$ The period of this service is two years ${ }^{13}$ - the equivalent of the active duty period of the inducted soldier, combatant or noncombatant. ${ }^{14}$

A man must register for the draft at age $18 .^{15}$ Each registrant is assigned to a local draft board, the board of his permanent place of residence. ${ }^{10}$ Registrants are to be classified as soon as possible after they first register. ${ }^{17}$ Early classification is facilitated by the recent creation of the I-H holding category, a preliminary classification of all registrants who are "not currently subject to processing for induction ...."18 By executive order, a random selection sequence determines the order of draft eligibility. ${ }^{19}$ Those registrants whose lottery numbers are sufficiently high may remain indefinitely in class $\mathrm{I}-\mathrm{H}$; those

fulfilling the alternate service requirement. In determining whether a particular job is acceptable for alternate service five factors are to be considered:

(1) National Health, Safety or Interest. The job must fulfill specifications of the law and regulations.

(2) Noninterference with the competitive labor market. The registrant cannot be assigned to a job for which there are more numerous qualified applicants not in Class I-O than spaces available. This restriction does not prohibit the approval of special programs such as Peace Corps or VISTA for alternate service by registrants in Class I-O.

(3) Compensation. The compensation will provide a standard of living to the registrant reasonably comparable to the standard of living the same man would have enjoyed had he gone into the service.

(4) Skill and talent utilization. A registrant may utilize his special skills.

(5) Job location. A registrant will work outside his community of residence. Subparagraphs (3), (4), and (5) of this paragraph are waiverable by

the State director when such action is determined to be in the national interest and would speed the placement of registrants in alternate service.

Id. $\$ 1660.6$ (as amended by 37 Fed. Reg. 5127 (1972)). Many of the same criteria had been developed earlier. See Local Board Mem. No. 64, SEL. SERv. L. REP. 2183 (1962, amended 1968) (rescinded, 5 SEL. SERv. L. REP. 8 (1972)); Local Board Mem. No. 98, Ser. Serv. L. Rep. 2200:7 (1969) (rescinded, 5 Ser. Serv. L. Rep. 8 (1972)).

1232 C.F.R. \$1660.6(3) (1972), quoted in note 11 supra, suggests, however, that jobs in which the registrant is well compensated should not be approved. The provision is waivable, however. Moreover, there is probably not a great difference between the serviceman's standard of living and that obtainable via most alternate service jobs when the market values of room and board are added to the serviceman's wages.

1332 C.F.R. $\$ 1660.7$ (d) (1972).

14 Military Selective Service Act $\$ 4($ b), 50 U.S.C. ApP. $\$ 454$ (b) (1970), as anended, 50 U.S.C.A. APP. $\$ 454$ (b) (Supp. 1972). Inductees, however, are subject in addition to a reserve commitment not applicable to alternate service workers. Id. §4(d), 50 U.S.C. App. \$454(d) (1970), as amended, 50 U.S.C.A. ApP. \$ 454(d) (Supp. 1972). Proposals to add a similar burden to conscientious objectors were dropped from the 1971 amendments. See H.R. REP. No. 433, 92d Cong., 1st Sess. 21 (1971).

15 Military Selective Service Act \$3, 50 U.S.C. APP. $\$ 453$ (1970), as amended, 50 U.S.C.A. APP. $\$ 453$ (Supp. 1972).

1032 C.F.R. $\$ 1613.12$ (1972). There are more than 4,000 such boards in the country. Central Conmittee for Conscientious Objectors, Handiook for ConSCIENTIOUS OBJECTORS 10 (1968).

1732 C.F.R. $\$ 1623.1$ (1972).

$18 I d . \S 1622.18$.

19 Proclamation No. 3945,34 Fed. Reg. 19,017 (1969), 50 U.S.C. APr. $\$ 455$ (1970); Exec. Order No. 11,497, 32 C.F.R. \$1631.1 (1972). 
with lower numbers will be reclassified out of the I-H category-as I-A unless they are eligible for another class. ${ }^{20}$

The proper classification of a man whose lottery number is below the I-H cutoff is determined from information he provides in the Registration Questionnaire (Form 100) ${ }^{21}$ which he receives when he registers. $^{22}$ The form calls for general information about the registrantsuch as his occupation and marital status-which is relevant to possible deferments or exemptions. ${ }^{23}$ It includes a question on the subject of conscientious objection: "Do you claim to be a conscientious objector based on moral, ethical or religious beliefs which prevent your participation in combatant and/or noncombatant military service?" 24 A registrant who answers affirmatively is furnished Form 150 and instructed to submit it to his board. ${ }^{25}$

On Form 150 the registrant must indicate whether his conscientious objection extends to noncombatant service and, if so, the reasons why. ${ }^{26}$ He must also describe his belief; why it is sufficiently religious, moral, or ethical; how and from what sources he acquired it; and the ways in which he has manifested it. ${ }^{27}$ In addition to Form 150, the registrant may present all relevant written information regarding his conscientious objection, and he may submit references in support of his claim. ${ }^{28}$

The registrant who receives Form 150 in response to a conscientious objector claim on his Registration Questionnaire must return it

20 Selective Service Registrants Processing Mameal $\$ 622.18$ in SEL. SERV. L. REP. 2622:1 (1972).

2137 Fed. Reg. 5121 (1972) (to be codified at 32 C.F.R. \$1621.9). See Selective Service Registrants Processing Manual $\$ 613$ in SEL. SERV. L. REP. 2613:1 (1972). For a discussion of the Mantal, which sets out a new procedure, see 5 SEL. SERV. L. REP. 3 (1972). The Registration Questionnaire was formerly called the Classification Questionnaire [Form 100]. 32 C.F.R. $\$ 1621.9$ (1971).

22 Selective Service Registrants Processing Manual \$613.4 in SEL. SERv. L. REP. $2613: 1$ (1972).

23 For a copy of Form 100, see Ser. SERv. L. Rep. 2156:3 (1972). Under the old system, shortly after a man registered, his local board sent him this form. The order in which the forms were sent was determined chronologically by birth date. 32 C.F.R. \$1621.9 (1971).

24 Sel. Serv. L. REp. 2156:3 (1972). Form 100 was in need of updating because it failed to inform the registrant that moral or ethical beliefs may entitle him to conscientious objector status. See United States v. VanCleve, 4 Sel. Serv. L. Rep. 3494 (D. Mrnn., Aug. 30, 1971). The new form bears a revision date of Nov. 5, 1971. SEL. SERV. L. REP. $2156: 3$ (1972).

2532 C.F.R. \$1621.11 (1972).

26 Form 150, 37 Fed. Reg. 487 (1972).

27 Id.

28 See 37 Fed. Reg. 5121 (1972) (to be codified at 32 C.F.R. $\$ 1621.12$ ). The old Form 150 provided space to list references who could provide the board with further information regarding the registrant's conscientious objection. Form 150 (superseded), SEL. SERV. L. REP. 2156:14 (1968). The submission of references has been of some importance in having a claim sustained; see Reisner, supra note 7 , at 538 , and registrants would be well-advised to continue to list them and submit letters from them. 
within thirty days. ${ }^{29}$ But his draft board will not necessarily consider the conscientious objector claim as soon as the form is received. The regulations require that a registrant be given the lowest classification to which he is entitled. ${ }^{30}$ I-A-available for induction-is the highest classification. I-A-O and I-O are the next highest, in that order. ${ }^{31}$ If, therefore, the registrant's questionnaire establishes grounds for some lower classification - such as a student deferment, a hardship deferment, or a sole surviving son exemption-his conscientious objector claim will not be considered; it will be held in abeyance until such time as it becomes relevant to his status. ${ }^{32}$

A man who has not made a conscientious objector claim at the time of registration may still do so at any time prior to the mailing of his induction notice by writing to his local board and requesting Form $150 .^{33}$ If at the time he files the form his status is I-A, and if his submission makes out a prima facie case for conscientious objector status, the board is obliged ${ }^{34}$ to reopen his classification to pass on the new claim. ${ }^{35}$

It is advantageous to file a conscientious objector claim as soon as possible, for a board is more likely to trust the sincerity of a claim that is promptly made. ${ }^{36}$ A claim made shortly before induction may

29 Sel. SeRv. L. Rep. 2156:14.1 (1968).

3032 C.F.R. $\$ 1623.2$ (1972).

31 Id.

32 Draft boards do not uniformly follow this rule, however. Some seem to pass on conscientious objector claims as soon as received. See, e.g., United States v. Owen, 415 F.2d 383 ( 8 th Cir. 1969).

33 See 32 C.F.R. $\$ 1621.11$ (1972) ; 37 Fed. Reg. 5123 (1972) (to be codified at 32 C.F.R. $\$ 1625.2$ ); notes $304-06$ infra \& accompanying text.

34 Mulloy v. United States, 398 U.S. 410 (1970). See 37 Fed. Reg. 5123 (1972) (to be codified at 32 C.F.R. $\$ 1625.2$ ). It is of moment to the registrant whether the board denies his claim after reopening or whether it refuses to reopen. If the board reopens and then denies the claim, the registrant has the same rights of personal appearance and appeal as after the initial classification. 32 C.F.R. $\$ 1625.11$ (1972). If the board refuses to reopen, however, no appeal is possible and the registrant is subject to immediate induction.

A rule that a board could reopen or not, in its discretion, would permit a board to deny appeal rights of all but its initial classifications. The difficulty with a rule allowing a registrant to force a board to reopen simply by submitting information, whether or not that information proves true, is that on its face it empowers a registrant, who cannot be drafted while appeals are pending, 37 Fed. Reg. 5124 (1972) (to be codified at 32 C.F.R. $\$ \$ 1626.6$ (appeal to appeal board), 1627.7 (1972) (appeal to Presidential Board) (formerly 32 C.F.R. $\$ \$ 1626.41,1627.8$ (1971)), to delay his induction indefinitely. The Supreme Court was satisfied that the board's power not to reopen where claims are "plainly incredible," coupled with the statutory criminal penalties for registrants who make false statements to their board, were sufficient to protect against this tactic. Mulloy v. United States, 398 U.S. 410, 418 n.7 (1970).

35 If, however, the registrant holds a lower classification when he files the form, the question of his conscientious objection should be held in abeyance. See text accompanying notes $29-32$ supra \& note 32 .

36 Common sense indicates that this would be true, and empirical studies of draft board operations show that the factor may be critical. See Reisner, supra note 7, at 536; Rabin, Do You Believe in a Supreme Being-The Administration of the Conscientious Objector Exemption, 1967 WIS. L. REv. 642, 680. 
well seem a calculated evasion. ${ }^{37}$ A board is not entitled to deny a claim, however, simply because it is filed late, ${ }^{38}$ so long as it is filed prior to the mailing of an induction order. ${ }^{39}$

The registrant can have all information relevant to his classification placed in his Selective Service file by sending it in writing to the board. ${ }^{40}$ When his conscientious objector claim becomes relevant to his classification, the local board considers whether to grant the claim "on the basis of the official forms of the Selective Service System and such other written information as may be contained in [the registrant's] file... . 41 The file will include the registrant's classification questionnaire, his Form 150, his correspondence with his board, and any material he has submitted to aid the board in arriving at a proper classification. It may also include unsolicited information from third parties $^{42}$ and information gathered by the board. The board can supplement an inadequate file by requesting a registrant to provide added information, ${ }^{43}$ by requesting other governmental agencies to provide information, ${ }^{44}$ or by issuing subpoenas directing "any person" to testify

37 See United States ex rel. Hemes v. McNulty, 432 F.2d 1182, 1187 (7th Cir. 1970) (dictum); United States v. Pritchard, 413 F.2d 663, 666 (4th Cir.), cert. denied, 396 U.S.' 995 (1969); Bishop v. United States, 412 F.2d 1064, 1068 (9th Cir. 1969); United States v. Henderson, 411 F.2d 224, 227 (5th Cir. 1969), cert. denied, 399 U.S. 916 (1970). Hemes, Pritchard, and Henderson are of questionable validity. In these cases, the courts were apparently willing to allow the registrants' sincerity to be thrown into question by the fact that the registrants had waited until their other deferment possibilities were exhausted before seeking I-O status. Other cases have rejected this conclusion on the ground that 32 C.F.R. $\$ 1623.2$ (1972) precludes consideration of a I-O claim if another deferment is available. United States v. Rutherford, 437 F.2d 182, 184-86 (8th Cir. 1971); United States v. Lemmens, 430 F.2d 619, 624 (7th Cir. 1970) ; United States v. Bornemann, 424 F.2d 1343, 1347-48 (2d Cir. 1970). See United States v. Broyles, 423 F.2d 1299, 1305-06 (4th Cir. 1970) (en banc) (discussing possible reasons why, in light of $\$ 1623.2$, those with other deferments may not choose to claim I-O status); United States v. Wingerter, 423 F.2d 1015, 1019 (5th Cir. 1970).

38 Clay v. United States, 403 U.S. 698, 702-03 (1971). See United States ex rel. Hemes v. McNulty, 432 F.2d 1182, 1187-88 (7th Cir. 1970) (dictum); United States v. Broyles, 423 F.2d 1299, 1305 (4th Cir. 1970) (en banc); cf. United States ex rel. Lehman v. Laird, 430 F.2d 96, 99 (4th Cir. 1970) (delay until Vietnam service was imminent was not, standing alone, a reason for denial of I-O claim); Capobianco v. Laird, 424 F.2d 1304 (2d Cir. 1970), vacated and remanded, 402 U..S. 969 (1971) (remanded for reconsideration in light of Ehlert v. United States, 402 U.S. 99 (1971) (fact that claim was made after induction notice was received was not, standing alone, sufficient to deny reopening of registrant's classification).

39 Ehlert v. United States, 402 U.S. 99 (1971) ; 32 C.F.R. \$1625.2 (1972). See notes 304-06 infra \& accompanying text.

40 See 37 Fed. Reg. 5121 (1972) (to be codified at 32 C.F.R. $\$ \$ 1621.12$, 1622.1(a)) ; 32 C.F.R. \$1625.1(a) (1972).

4132 C.F.R. $\$ 1623.1$ (b) (1972).

42 See 37 Fed. Reg. 5121 (1972) (to be codified at 32 C.F.R. $\$ \S 1621.12$, $1622.1(\mathrm{a}))$.

4332 C.F.R. $\$ 1621.13$ (1972).

$44 I d$. $\$ 1621.14$. The local board can itself request information from local agencies. It must request the State Director to obtain information from state or national welfare or governmental agencies. Id. 
before it and to produce relevant documents. ${ }^{45}$ Information within the personal knowledge of any board member may also be considered. ${ }^{46}$ In all cases, however, information the board receives must be reduced to writing and placed in the file for it to be legitimately considered. ${ }^{47}$ Its inclusion in the file is deemed to give the registrant notice that it is before the board. ${ }^{48}$

While the board has power to seek out for itself information pertaining to the proper classification of a registrant, the regulations impose on it no duty to do so. Since under the regulations the registrant bears the burden of convincing the board that he is entitled to a classification lower than $I-A,{ }^{49}$ the board has little incentive to supplement an inadequate file; if information in the file is insufficient to show whether or not the registrant is entitled to a deferment or exemption, the registrant has not made his case, and the board may properly deny his claim. ${ }^{50}$

A registrant dissatisfied with the board's classification has a right either to appeal immediately ${ }^{51}$ or to appear personally before the board. ${ }^{52}$ The Selective Service System depicts the personal appearance

45 Id. $\$ 1621.15$.

$4 \mathrm{Id}$. $\$ 1623.1(\mathrm{~b})$.

47 Id.

$48 I d$. $\$ 1641.5$ (1972). The registrant is not informed when the local board receives information, whether favorable or not. But he does have the right to inspect his file at any time, id. $\$ \S 1606.32$ (a) (1), 1670.8(a) (1), which is deemed to give him notice. See, e.g., United States v. Mendoza, 295 F. Supp. 673, 680 (E.D.N.Y. 1969). One recent case suggests, however, that the registrant is not deemed to have notice of adverse information when he is "justifiably unaware" of its insertion in his file. United States v. Fisher, 442 F.2d 109, 115-16 (7th, Cir. 1971) (registrant incorrectly informed by board employee that nothing had been added to his file). Similarly, in United States v. Owen, 415 F.2d 383, 388 (8th Cir. 1969), the court said:

While we may charge literate registrants with knowledge of information with which they are directly confronted, such as that contained on registration or classification cards, we may not expect a working knowledge of selective service regulations or inquiry at the office of the local board to guard against information received from an outside source.

The court held that the registrant before it had been

denied a basic procedural right when he was classified by the local board and the appeal board without first being apprised of adverse information in his file and being given an opportunity to rebut it.

Id. at 389.

49 See 32 C.F.R. $\$ 1622.10$ (1972) ("In Class I-A shall be placed every registrant who has failed to establish to the satisfaction of the local board, subject to appeal hereinafter provided, that he is eligible for classification in another class."). See also id. $\$ 1623.2$; 37 Fed. Reg. 5121 (1972) (to be codified at 32 C.F.R. $\$ 1622.1$ ).

50 Similarly, the regulations provide that "the board shall proceed with the registrant's classification whenever he fails to provide the board in a timely manner with any information concerning his status which he is requested or required to furnish." 32 C.F.R. $\$ 1623.1(\mathrm{~b})$ (1972). The old regulations specifically provided for classification whenever Form 100 was not returned in time. 32 C.F.R. $\$ 1623.1$ (b) (1971).

5137 Fed. Reg. 5123 (1972) (to be codified at 32 C.F.R. \$1626.1). No appeal is allowed from the initial I-H classification. Id.

52 Id. 5122 (to be codified at 32 C.F.R. $\$ 1624.1(\mathrm{a})$ ). The new regulations allow conscientious objector claimants to make a personal appearance before classification instead of following classification, at their option. Id. (to be codified at 32 C.F.R. 
as an opportunity for the registrant to "discuss his case with his local board members as he would with his neighbors." 53 The regulations provide:

At any such appearance, the registrant may present evidence, including witnesses, may discuss his classification, may point out the class or classes in which he thinks he should have been placed, and may direct attention to any information in his file which he believes the local board has overlooked or to which he believes it has not given sufficient weight. The registrant may present such further information as he believes will assist the local board in determining his proper classification. Such information shall be in writing, or if oral, shall be summarized in writing by the registrant and, in either event, shall be placed in the registrant's file. ${ }^{54}$

The personal appearance is closed to the public, ${ }^{65}$ and procedural protections are far more limited than is customary in proceedings involving critical administrative determinations. ${ }^{50}$ The aim of such a procedure, according to General Hershey, is to keep the System "simple enough so that the average citizen can see how it works." 57 Prior to the 1971 amendments, it was discretionary with the local board whether to allow "person[s] to appear before it with or on behalf of a registrant," 58 and the registrant was typically the only witness at the personal appearance. The amendments provide that "[s] ubject to reasonable limitations on the number of witnesses and the total time allotted to each registrant, each registrant shall have the right to present wit-

$\S 1624.1$ (b)) ; see 50 U.S.C.A. App. $\$ 471 \mathrm{a}(\mathrm{b})$ (1) (Supp. 1972). The 1971 amendments provided, for the first time, that a quorum of the board-that is, a majority of the board's members-must attend the personal appearance. 50 U.S.C.A. ApP. \$471a (b) (3) (Supp. 1972), amending 50 U.S.C. ApP. \$ 471a(b) (1970). Previously the presence of one board member was sufficient. See 32 C.F.R. $\$ 1624.2$ (1971).

53 Selectrve Service System, The Ciassification Process 158 (Special Monograph No. 5, 1950).

5437 Fed. Reg. 5122 (1972) (to be codified at 32 C.F.R. \$1624.4(b)). The right to present evidence and witnesses was not included under the old regulations. 32 C.F.R. $\$ 1624.2$ (b) (1971).

55 For a discussion of the rationale and the regulatory basis for this practice, see Reisner, The Conscientious Objector Exemption: Administrative Procedures and Judicial Review, 35 U. CHr. L. Rev. 686, 697-98 (1968).

56 Although the 1971 amendments provided that Selective Service System regulations must be prepublished, they continued the System's exemption from the operation of the Administrative Procedure Act. Military Selective Service Act $\$ 13(\mathrm{~b}), 50$ U.S.C.A. APP. $\$ 463(\mathrm{~b})$ (Supp. 1972), annending 50 U.S.C. APP. $\$ 463(\mathrm{~b})(1970)$. That exemption may originally have been unthinkingly granted to the System. See Note, The Selective Service, 76 YaLE L.J. 160, 183 n.133 (1966).

57 Hearings on S. 4164 Before the Senate Military Affairs Comm., 76th Cong., 3d Sess. 384 (1940).

5832 C.F.R. \$1624.1(b) (1971); see Uffelman v. United States, 230 F.2d 297, 303 (9th Cir. 1956) (upholding local board's refusal to allow registrant to present two witnesses). 
nesses on his behalf before the local board." 59 The amendments do not, however, change the provision of the regulations denying the registrant representation by legal counsel, ${ }^{60}$ although the Senate version of the bill would have granted "the right to be accompanied and advised by private counsel." 61

The regulations do not provide for the personal appearance to be transcribed. Even when the board clerk keeps minutes of the meetings, they are not generally made a matter of public record. If a registrant asks the board to allow him to bring his own stenographer, the board may acquiesce or not, in its discretion. ${ }^{62}$ But a registrant does have the right, after the hearing has been concluded, to prepare his own summary of what transpired and to submit it for inclusion in the file. ${ }^{63}$ The board, of course, may also place a summary in the file. After the personal appearance, the board again decides on the registrant's classification and informs him of its decision. ${ }^{64}$ The registrant who has had a personal appearance and wishes to contest his classification further has a right to appeal. ${ }^{65}$

There are ninety-four appeal boards ${ }^{66}$ and a Presidential Appeal Board, formally named the National Selective Service Appeal Board. While every registrant may appeal to his appeal board, there is a right to seek further review before the Presidential board only if the appeal

59 Military Selective Service Act $\$ 22(b)(2), 50$ U.S.C.A. App. $\$ 471 a(b)(2)$ (Supp. 1972), antending 50 U.S.C. APP. \$ 471 (1970). A registrant who "does not speak English adequately" has a right to appear with an interpreter. 37 Fed. Reg. 5122 (1972) (to be codified at 32 C.F.R. $\$ 1624.4(d)$ ).

6037 Fed. Reg. 5122 (1972) (to be codified at 32 C.F.R. $\$ 1624.4(\mathrm{e})$ ). In United States v. Weller, 309 F. Supp. 50 (N.D. Cal. 1969), the registrant argued that the regulation denying him the right to have his retained attorney accompany him at the personal appearance was not authorized by the Selective Service Act and, if authorized, was unconstitutional. The Court found for the registrant, seemingly on both grounds. 309 F. Supp. at 56. The government appealed the decision to the Supreme Court of the United States, but that Court concluded, after argument, that it lacked jurisdiction. It remanded the case to the United States Court of Appeals for the Ninth Circuit. 401 U.S. 254 (1971).

61 See H.R. Rep. No. 433, 92d Cong., 1st Sess. 29 (1971).

62 See O'Brien v. Resor, 423 F.2d 594, 598 (4th Cir. 1970); United States v. Tittlerud, 2 Ser. Serv. L. REp. 3283 (D. Minn. 1969). The board may not allow the registrant to tape record his personal appearance. Ietter to all State Directors (00-43) from Daniel J. Cronin, Assistant Deputy Director, Operations, Oct. 26, 1971, Ser. Serv. I. Rep. 2200:89.

6337 Fed. Reg. 5122 (1972) (to be codified at 32 C.F.R. $\$ 1624.4(b)$ ).

$64 I d$. (to be codified at 32 C.F.R. $\$ 1624.6$ ). A majority of the local board is the necessary quorum when voting on a classification. 32 C.F.R. $\$ 1604.56$ (1972). The National Director prescribes the number of members of the local board. Id. $\$ 1604.52$. A 3- to 5-member board is typical. Until the recent regulations, a local board had to consist of at least 3 members. 32 C.F.R. $\$ 1604.52$ (a) (1971).

6537 Fed. Reg. 5123 (1972) (to be codified at 32 C.F.R. \$1626.1). The registrant who decides not to exercise his right to a personal appearance may also contest the action of his local board before an appeal board. Id. (to be codified at 32 C.F.R. $\$ \$ 1626.1,2)$. See note 181 infra.

66 See 32 C.F.R. $\$ 1604.21$ (1972); Central Commitree for Conscientiaus OBJECTORS, HANDBOOK FOR CONSCIENTIOUS OBJECTORS 10 (1970). 
board is divided. ${ }^{67}$ The registrant is not the only person who can appeal. The State and National Directors of the Selective Service may appeal at any time. ${ }^{68}$

The new regulations provide that when the National or State Director decides to appeal, he "shall place in the registrant's file a written statement of his reasons for taking such appeal." ${ }^{69}$ When the registrant appeals, he "may attach to his appeal a statement specifying the reasons he believes the classification inappropriate, directing attention to any information in his file which he believes received inadequate consideration, and setting out more fully any information which was submitted." 70 Prior to the amendments, the appeal board was to classify the registrant anew solely on the basis of the evidence contained in his file. ${ }^{71}$ The 1971 statutory amendments, however, created for the first time the right to a personal appearance before both the appeal board ${ }^{72}$ and the Presidential board. ${ }^{73}$ Both appellate bodies may now consider information presented by the registrant during his personal appearance. ${ }^{74}$ A quorum of the appeal board must attend the appearance, ${ }^{75}$ but there is no right to present witnesses at that stage. ${ }^{76}$

When a registrant has exhausted his appeals within the Selective Service System, he can pursue the issue of classification further only by presenting enough new information to require a reopening. ${ }^{77}$

\section{B. Avenues of Judicial Review}

A registrant whose conscientious objector claim has been finally denied within the Selective Service System has several alternatives open to him. He may refuse to submit to induction and defend an ensuing

6737 Fed. Reg. 5124 (1972) (to be codified at 32 C.F.R. $\$ 1627.1(b)$ ).

$68 \mathrm{Id}$. 5123 (to be codified at 32 C.F.R. $\$ 1626.1$ ). Before the new regulations, the government appeal agent, whose general duty was to advise and aid both registrants and local board members as to applicable law, had a right to appeal local board decisions. 32 C.F.R. \$1626.2(a) (1971). The appeal agent's duties were described in id. $\$ 1604.71$. The new regulations abolish the position of government appeal agent. 36 Fed. Reg. 23,375 (1971).

6937 Fed. Reg. 5123 (1972) (to be codified at 32 C.F.R. §1626.3(a)).

$70 \mathrm{Id}$. (to be codified at 32 C.F.R. $\$ 1626.3(\mathrm{e})$ ).

7132 C.F.R. \$1626.24 (1972).

72 Military Selective Service Act, \$22(b) (1), 50 U.S.C.A. Apr. $\$ 471 a(b)$ (1), amending 50 U.S.C. APP. $\$ 471$ (1970); 37 Fed. Reg. 5123 (1972) (to be codified at 32 C.F.R. $\$ 1626.3(\mathrm{c}))$.

73 Military Selective Service Act, $\$ 22$ (b) (1), 50 U.S.C.A. App. $\$ 471$ a (b) (1) (Supp. 1972), amending 50 U.S.C. ApP. \$ 471 (1970). 37 Fed. Reg. 5124 (1972) (to be codified at 32 C.F.R. $\$ 1627.3(d)$ ). The statute allows an appearance before "any appeal board of the Selective Service System." In view of the regulation, it is a moot issue whether this includes the National Board.

7437 Fed. Reg. 5124 (1972) (to be codified at 32 C.F.R. $\$ \$ 1626.4(\mathrm{~g})(3)$, $1627.4(\mathrm{~g})(3))$.

75 Id. (to be codified at 32 C.F.R. $\$ 1626.4(\mathrm{e})$ ).

$76 \mathrm{Id}$. (to be codified at 32 C.F.R. $\$ 1626.4(\mathrm{~d})$ ).

77 See note 34 supra. 
criminal prosecution on the ground that he was erroneously classified. ${ }^{78}$ If he loses he will be subject to a maximum penalty of five years' imprisonment and a $\$ 10,000$ fine. ${ }^{79}$ The registrant may, instead, give up the battle, accept his classification, and enter the military. Finally, he may accept induction but petition for habeas corpus immediately upon entering the military. ${ }^{80}$ The ground for relief will be that his induction was illegal because it resulted from misclassification. The registrant will be assigned to duties involving minimal conflict with his asserted beliefs while the petition is pending. ${ }^{81}$ If he loses, however, he will be in the military and subject to court-martial for refusal to obey orders. $^{82}$

78 Estep v. United States, 327 U.S. 114 (1946).

79 Military Service Act $\$ 12(\mathrm{a}), 50$ U.S.C. APP. $\$ 462$ (a) (1970), as amended, 50 U.S.C.A. ApP. $\$ 462$ (a) (Supp. 1972). Although the statute sets that maximum sentence, another section provides, "[N] otwithstanding any other provision of law, any registrant who has failed or refused to report for induction shall continue to remain liable for induction and when available shall be immediately inducted . . . ." $I d$. $\$ 4(\mathrm{a})$ 50 U.S.C. APP. $\$ 454(\mathrm{a})$ (1970), as amended, 50 U.S.C.A. APP. $\$ 454$ (a) (Supp. 1972). Pursuant to the statute, an executive order directs that those failing or refusing to report for induction be inducted as soon as available. Exec. Order No. 11,360, 32 Fed. Reg. 9787, 9789 (1967) (codified at 32 C.F.R. $\$ 1631.7$ (c) (1972)). If this order were complied with, a man who had served a prison sentence or paid a fine for refusing to submit to induction would be ordered again to submit and if he refused be subject repeatedly to the maximum sentence. See McGraw v. United States, 156 F.2d 539 (1st Cir. 1946). That result, coupled with restraints placed on the Department of Justice's power to decline to prosecute, see Military Selective Service Act $\$ 12$ (c), 50 U.S.C. App. $\$ 462$ (c) (1970), as amended, 50 U.S.C.A. APP. $\$ 462$ (c) (Supp. 1972), appears to have been the purpose of section 4(a), which was added to the statute in 1967. See H.R. Rep. No. 267, 90th Cong., 1 st Sess. 43 (1967) (sectional analysis of Military Selective Service Act \$1(a) (b), 50 U.S.C. APr. $\$ 454(\mathrm{a})$ (1970), as anended, 50 U.S.C.A. APP. \$454(a) (Supp. 1972)).

80 See Eagles v. United States ex rel. Samuels, 329 U.S. 304 (1946).

81 Dep't of Defense Directive No. 1300.6, §VII(c), SEL. SERv. L. REP. 2330 (Aug. 20, 1971).

82 The efficacy of relief by habeas has sometimes been questioned. In Estep v. United States, 327 U.S. 114 (1946), which involved the issue whether habeas was the sole avenue to judicial review of a misclassification or whether misclassification could serve as a defense to a criminal prosecution for refusal to submit to induction as well, Mr. Justice Murphy, in a concurring opinion, said that the habeas remedy

may be quite illusory in many instances. It requires one first to enter the armed forces and drop every vestige of civil rights. Military orders become the law of life and violations are met with summary court-martial procedure. No more drastic condition precedent to judicial review has ever been framed. Many persons with religious or conscientious scruples are unable to meet such a condition. But even if a person is inducted and a quest is made for a writ of habeas corpus, the outlook is often bleak. The proceeding must be brought in the jurisdiction in which the person is then detained by the military, which may be thousands of miles removed from his home, his friends, his counsel, his local board and the witnesses who can testify in his behalf. Should he overcome all these obstacles and possess enough money to proceed further, he still faces the possibility of being shifted by the military at a moment's notice into another jurisdiction, thus making the proceeding moot. There is little assurance, moreover, that the military will treat his efforts to obtain the writ with sympathetic understanding. These practical difficulties may thus destroy whatever efficacy the remedy might otherwise have and cast considerable doubt on the assumption that habeas corpus proceedings necessarily guarantee due process of law to inductees.

Id. at 129-30. 
Although the law makes these alternatives ${ }^{83}$ available to registrants who have exhausted their remedies within the Selective Service System, ${ }^{84}$ there is some question whether it is factually consistent with his claim for a conscientious objector whose sincere claim has erroneously been rejected within the Selective Service System to accept induction. Does the fact that a man enters the military itself demonstrate that he does not entertain scruples of sufficient depth and sincerity to entitle him to conscientious objector status? Is it disqualifying even when the purpose of entering is to seek relief by habeas corpus?

At first blush it would appear that the man who objects only to combatant service could in good conscience enter the military to challenge his classification, but that accepting induction would belie the

Mr. Justice Douglas, dissenting in Ehlert v. United States, 402 U.S. 99, 108 (1971), claimed that in-service remedies are inadequate because of military intolerance towards conscientious objectors. He documented this with tales of atrocities the military has committed on conscientious objectors from World War I up until the present. He also claimed that military factfinders do not have the sensitivity to the rights involved to be entrusted with the administrative determination whether a man is a conscientious objector, and that it will be more difficult for a man to prove his conscientious objection once in the military where he is away from friends who could provide evidence for him. The Court, by contrast, thought in-service procedures adequate and military tribunals as sensitive to conscientious objectors' rights as are draft boards. 402 U.S. at 104 n.8.

83 There is a final method whereby a classification may be reviewed judicially and that is by preinduction suit by the registrant for declaratory and/or injunctive relief. It is obviously preferable to many registrants who can afford to bring such suits to determine their status before making the decision whether to submit to induction. Preinduction suits do, however, contravene a basic policy against allowing "litigious interruptions" to the induction procedure, Falbo v. United States, 320 U.S. 549,554 (1944), and they are not generally allowed. See Military Selective Service Act $\$ 10$ (b) (3), 50 U.S.C. APP. $\$ 460$ (b) (3) (1970), as amended, 50 U.S.C.A. APP. $\$ 460$ (b) (3) (Supp. 1972). While the precise limits on which cases will permit of preinduction relief have not yet been drawn, see Fein v. Selective Serv. Local Bd. No. 7, 40 U.S.L.W. 4280 (U.S. Mar. 21, 1972); Breen v. Selective Serv. Local Bd. No. 16, 396 U.S. 460 (1970); Boyd v. Clark, 393 U.S. 316 (1968); Clark v. Gabriel, 393 U.S. 256 (1968); Oestereich v. Selective Serv. Local Bd. No. 11, 393 U.S. 233 (1968); Wolff v. Selective Serv. Local Bd. No. 16, 372 F.2d 817 (2d Cir. 1967), that form of relief will not be available to the bulk of conscientious objectors, if, indeed, it is available to any of them. See Clark v. Gabriel, 393 U.S. 256 (1968).

84 As a general rule, a man can receive judicial review of the correctness of his classification, either by way of habeas corpus or as a defense to a criminal prosecution, only if he has exhausted his remedies within the Selective Service System. Military Selective Service Act $\$ 10$ (b) (3), 50 U.S.C. App. $\$ 460$ (b) (3) (1970), as amended, 50 U.S.C.A. APP. $\$ 460$ (b) (3) (Supp. 1972). Edwards v. United States, 395 F.2d 453 (9th Cir.), cert. denied, 393 U.S. 845 (1968); DuVernay v. United States, 394 F.2d 979 ( 5 th Cir. 1968), aff'd per curiam by an equally divided contr, 394 U.S. 309 (1969); cf. Clark v. Gabriel, 393 U.S. 256 (1968); Falbo v. United States, 320 U.S. 549 (1944). The exhaustion principle is not limited to presently available administrative remedies; cf. Fay v. Noia, 372 U.S. 391 (1963); if a registrant fails to pursue his appeals he is permanently precluded from judicial review; cf. Johnson v. Zerbst, 304 U.S. 458, 464 (1938) ("A waiver [of a constitutional right] is ordinarily an intentional relinquishment or abandonment of a known right or privilege.").

The general rule does, however, have exceptions; see McKart v. United States, 395 U.S. 185 (1969); cf. Breen v. Selective Serv. Local Bd. No. 16, 396 U.S. 460 (1970); Oestereich v. Selective Serv. Local Bd. No. 11, 393 U.S. 233 (1968), which, despite recent Supreme Court pronouncements, are of uncertain scope. Compare McKart v. United States, supra, with DuVernay v. United States, supra. 
claim of the registrant who seeks total exemption. ${ }^{\text {s5 }}$ This depends, however, on the basis for the I-O claimant's objection to noncombatant service. If he says it conflicts with his conscience to wear a military uniform or to be any part of an organization that participates in war, the sincerity of his claim is at least somewhat called into question by his entry into the military to contest his classification. A more limited objection to noncombatant service-that the registrant cannot, because of his beliefs, personally contribute to the war effort, as he would, for example, by helping cure injured persons who would eventually return to combat-is not, however, necessarily inconsistent with acceptance of a brief period of service in the military.

It may be objected, however, that the only rational reason for a registrant (whether he claims I-O or I-A-O status) to choose habeas as a means of contesting his classification instead of defending a criminal prosecution is to give himself the opportunity to avoid a prison sentence and become a cooperating member of the military in case he fails in his conscientious objector claim. A willingness to cooperate, even though induced by the threat of imprisonment for noncooperation, may conceivably be inconsistent with a valid conscientious objector claim. If it is, any conscientious objector claimant, I-A-O or I-O, who enters the military to contest his classification thereby reveals that he does not qualify as a conscientious objector, unless a reason other than ability to avoid a prison sentence can explain his choice of the habeas route. ${ }^{86}$

Under two hypotheses it might be rational for the registrant to contest his classification by habeas even if he planned to refuse to cooperate in the event his petition failed. It might be rational if the registrant were more likely to prevail in a habeas proceeding than in defending a criminal prosecution on the ground of misclassification. ${ }^{87}$

$85 \mathrm{This}$ is so because the registrant seeking alternate service must claim that it violates his convictions to serve in any military capacity.

86 The analysis is complicated somewhat by the fact that even persons who do defend a criminal prosecution rather than seek habeas may be given the opportunity to avoid imprisonment and cooperate with the military after they are convicted by being paroled into the armed forces. See 32 C.F.R. $\$ \$ 1643.1-.13$ (1972), as amended, 37 Fed. Reg. 5125 (1972). A registrant does not, however, have a right to parole into the military, and such parole is not uniformly offered a convicted registrant. (If the government did afford it uniformly it would allow a criminal prosecution to serve the function of a preinduction suit-allowing the registrant judicial review of his classification before his ultimate decision whether to submit-whenever a registrant was willing to have a conviction on his record. This result should be unacceptable to the government for the same reasons that it strongly opposes the general availability of the preinduction remedy. See cases cited note 83 supra.) A man who decides to defend a criminal prosecution rather than enter the military and seek habeas must therefore be willing to serve a prison sentence, for he may or may not have a later opportunity to enter the military. A man who follows the habeas route, by contrast, will assuredly be given the opportunity to cooperate with the military if his petition fails.

87 It would seem, however, that the man defending a criminal prosecution is advantaged. If he is indigent, he will be provided with counsel. Moreover, the 
It also might be sensible for a registrant whose beliefs permitted him to choose the habeas route if, in the event of losing, he would be better treated by the system of military justice than by the civil courts. Neither of these hypotheses, however, has any substantial foundation in common experience.

Another possible reason for entering the military to contest one's classification might be to obtain more information on what the military is like in order to decide whether to cooperate if one's claim is denied. This justification will not be sufficient, however, if unconditional opposition to service is considered the sine qua non of entitlement to conscientious objector status. ${ }^{88}$

Whether a person who accepts induction can qualify as a conscientious objector depends ultimately upon the scope of the conscientious objector exemption. Congress could have exempted conscientious objectors simply because there is a group of persons who will not serve even under the threat of imprisonment. Under that view Congress' aim would be to force persons to serve as fully as the threat of imprisonment could induce them to serve. ${ }^{89}$ Rather than imprison persons when the threat of imprisonment would not be effective, however, there would be an alternative form of service, also beneficial to the nation, which they would, at least under compulsion, perform. If this theory underlies the conscientious objector provisions, a person who would make the choice of entering the military rather than going to prison would not, by definition, be entitled to conscientious objector status; and no claimant to either I-O or I-A-O status who was in fact entitled to that status could enter the military-even if he filed for habeas immediately upon entering. ${ }^{90}$

government bears the burden of proving the case against him beyond a reasonable doubt, whereas in habeas the registrant bears the burden of proof. For other disadvantages of habeas, see note 82 supra.

88 Concerning the difficult question of the degree of certainty of opposition that is necessary in order to qualify as a conscientious objector, see Mansfield, Conscientious Objection-1964 Term, 1965 RELIGION \& PUB. ORDER 3, 19.

89 Under this view of the exemption, the System discovers that it is in error in denying a man's claim on grounds of lack of sincerity or lack of depth any time the man goes to prison rather than accepting induction. The System cannot, however, correct the error. Objectors' willingness to go to prison will prove that they qualify only as long as prison sentences are actually carried out. (1970):

90 Cf. Mr. Justice Black's approach in Welsh v. United States, 398 U.S. 333

Both [Seeger and Welsh] strongly believed that killing in war was wrong, unethical, and immoral, and their consciences forbade them to take part in such an evil practice. Their objection to participating in war in any form could not be said to come from a "still, small voice of conscience"; rather, for them that voice was so loud and insistent that both men preferred to go to jail rather than serve in the Armed Forces. There was never any question about the sincerity and depth of Seeger's convictions as a conscientious objector, and the same is true of Welsh. 
A different interpretation of Congress' underlying purpose in enacting the conscientious objector provisions is possible, however: that Congress decided that even those persons whom threat of imprisonment might induce to serve should not be coerced to do so if the service would violate their deeply-held conscientious scruples and if they can be used in some capacity more in keeping with their beliefs. On this theory of the conscientious objector provisions, a man does not show himself disqualified by entering the military rather than going to prison. The United States Court of Appeals for the District of Columbia Circuit seems to have taken this view. In the recent case of Gruca v. Secretary of the Army, ${ }^{91}$ it rejected the Government's contention that a sincere conscientious objector could not allow himself to submit to induction into the Army. The court thought that "a registrant should have the right to attempt to prove the sincerity of his claim without risking the obloquy of a prison term if he is unsuccessful." 92

It is unnecessary to resolve the question of congressional purpose, however, for even if the exemption extends only to persons who prefer imprisonment to the objectionable service, reasons of policy dictate against ruling the traditional remedy of habeas corpus unavailable to the claimant who has entered the military. ${ }^{93}$ If one were to accept the view that the conscientious objector claimant who accepts induction thereby undermines his claim, a man who has been unsuccessful within the Selective Service System and is unwilling to abandon his claim would have to refuse induction. If the courts then uphold his classification, he would be in prison and not in the military. It is surely more consonant with the ultimate aim of the Selective Service statutethe mobilization of armed forces-to encourage the registrant to seek review by habeas. If he does that and loses his claim, the likelihood of his serving in the military is maximized. ${ }^{94}$

$I d$. at 337. To use the fact that an objector went to jail rather than entering the military to show his sincerity, or as one factor tending to show sincerity, is distinct, however, from using failure to go to prison as either conclusive of insincerity or as one factor tending towards a finding of insincerity.

91436 F.2d 239 (D.C. Cir. 1970), cert. denied, 401 U.S. 978 (1971).

92 Id. at 243.

93 Another reason for holding habeas available to a conscientious objector is that the only inquiry open to a court hearing the habeas petition of a serviceman claiming that his draft board misclassified him is whether his Selective Service file shows a basis in fact for the classification his draft board gave him. See text accompanying notes 96-97 infra. A court giving weight to the petitioner's entry into the military, occurring subsequent to the Selective Service System's classification, would violate that standard.

94 This analysis would be undercut only if the unsuccessful conscientious objector claimant who does accept induction were more troublesome than beneficial to the military.

It is true, of course, that fewer persons will abandon their claims under a system where they can be raised without risking imprisonment than if the only avenue of review in conscientious objector cases were defense of a criminal proscution. The 


\section{The Basis-in-Fact Test}

Whether the registrant who refuses to accept his Selective Service classification challenges it in a criminal proceeding or by habeas after induction, he faces a standard of judicial review that is the "narrowest known to the law." 95 The evidence a court may consider in reviewing the correctness of a registrant's classification is limited to evidence appearing in his Selective Service file. ${ }^{96}$ Section $10(\mathrm{~b})(3)$ of the Military Selective Service Act provides that a court may overturn a decision of the Selective Service System only if there is "no basis in fact" for the classification. ${ }^{97}$ The statute, however, only represents a codification of a standard the Supreme Court had earlier enunciated.

The Supreme Court first formulated the "basis-in-fact" standard for Selective Service cases in Estep $v$. United States. ${ }^{98}$ The issue in Estep was whether a registrant who had refused to submit to induction could defend his criminal prosecution on the ground that he should not have been classified I-A, or whether the only method of review was postinduction habeas. The lower court had held that the provision of the Selective Training and Service Act of 1940 that "the decisions of . . . local boards shall be final except where an appeal is authorized in accordance with such rules and regulations as the President may prescribe" precluded judicial review except by habeas. The Supreme Court ruled against the Government on this point, holding that a registrant could obtain review in a criminal proceeding. The finality provision, it said, did not empower the boards to act beyond the powers the Act and regulations conferred upon them. A registrant could accordingly defend a charge of refusing to submit to induction by showing that the board's classification was "lawless and beyond its jurisdiction." 99 Rather than leave the finality provision without any meaning,

number of persons in the military could conceivably increase under a system where habeas was not available to conscientious objector claimants. This could happen if there were a larger number of persons who abandoned claims that would ultimately have been sustained than the number of persons with losing claims who refused induction. Even if that occurred, however, the added military personnel would, by hypothesis, be people who had a statutory right not to be there.

Provisions for parole into the military for persons convicted of refusing induction do not undercut this analysis. Such parole is not, and cannot be, made uniformly available to convicted registrants. See note 86 supra. Even when a man is given the chance to enter the armed forces after conviction, it is reasonable to suppose that he is less likely to enter the service as a parolee after conviction for refusing induction than he would be to complete military service if he accepted induction initially, petitioned for habeas and his petition was denied.

95 Blalock v. United States, 247 F.2d 615, 619 (4th Cir. 1957). The same standard of review prevails in preinduction suits, see cases cited note 83 supra. 96 Cox v. United States, 332 U.S. 442 (1947).

97 Military Selective Service Act $\$ 10(\mathrm{~b})(3), 50$ U.S.C. APP. $\$ 460(\mathrm{~b})(3)$ (1970), as anended, 50 U.S.C.A. APP. $\$ 460$ (b) (3) (Supp. 1972).

98327 U.S. 114 (1946). The Court had earlier formulated the standard in deportation cases. See cases cited id. at 123 n.14.

99 Id. at 121 . 
however, the Court derived from it the "no basis-in-fact" standard of judicial review : ${ }^{100}$

The provision making the decisions of the local boards "final" means to us that Congress chose not to give administrative action under this Act the customary scope of judicial review which obtains under other statutes. It means that the courts are not to weigh the evidence to determine whether the classification made by the local boards was justified. The decisions of the local boards made in conformity with the regulations are final even though they may be erroneous. The question of jurisdiction of the local board is reached only if there is no basis in fact for the classification which it gave the registrant. ${ }^{101}$

In theory, the basis-in-fact test seems to mean that any evidence supporting the board's decision requires a court to affirm regardless of countervailing evidence in the record. ${ }^{102}$ It is unclear whether the test is actually deemed to carry that meaning or, if not so extreme, how far it is from that formulation. What is certain is that the test is intended to provide for narrower judicial review than the "substantial evidence test" applied to decisions of most administrative agencies. ${ }^{103}$ As many courts apply them, however, the two tests may differ little.104

100 The deportation cases, where the Court had earlier derived a basis-in-fact standard of review, see note 98 supra, also involved a statute that characterized the administrative action as "final." See Bridges v. Wixon, 326 U.S. 135, 167 (1945) (Stone, C.J., dissenting).

101327 U.S. at 122-23.

102 See Bridges v. Wixon, 326 U.S. 135, 167 (1945) (Stone, C.J., dissenting) (deportation proceeding); accord, $4 \mathrm{~K}$. DAvIs, AdMINIsTratrve LAW TREATISE $\$ 29.07$, at 150 (1958). But see the opinion for the Court in Bridges overturning an administrative decision that was supported only by "flimsy" evidence. 326 Ü.S. at 156. See also text accompanying note 174 infra.

103 The issue under that test is whether there is "substantial evidence" to support the agency's decision. Section $10(\mathrm{e})$ of the Administrative Procedure Act provides that a reviewing court should set aside an agency's determination only if it is "unsupported by substantial evidence" and that "[i]n making the foregoing determinations, the court shall review the whole record or those parts of it cited by a party . . ." Administrative Procedure Act $\$ 10(\mathrm{e}), 5$ U.S.C. $\$ 706$ (1970). See Universal Camera Corp. v. NLRB, 340 U.S. 474 (1951), for the Supreme Court's construction of the substantial evidence test. See also Jaffe, Judicial Review: "Substantial Evidence on the Whole Record", 64 HARv. L. Rev. 1233 (1951).

104 See $4 \mathrm{~K}$. Davis, supra note $102, \S 29.07$, at 150-52; M. ForkosCh, Treatise on ADMINISTRATIVE LAw \$338, at $727 \mathrm{n} .19$ (1956); Hansen, The Basis-in-Fact Test in Judicial Review of Selective Service Classifications: A Critical Analysis, 37 BrookLyn L. Rev. 453, 471-81 (1971) ; Comment, The Selective Service System: An Adninistrative Obstacle Course, 54 CalrF. L. Rev. 2123, 2140 (1966); Comment, Fairness and Due Process Under the Selective Service System, 114 U. PA. L. REv. 1014, 1023 (1966) (suggesting a "minimum test of legality" is used) ; Note, Selective Service and Judicial Review, 32 VA. L. REv. 618, 625-26 (1946).

Since the Supreme Court has never clarified the precise meaning of the basis-infact test, lower courts differ considerably in the way they apply it. For cases interpreting the test as allowing only very narrow review, see, e.g., Speer v. Hedrick, 419 F.2d 804 (9th Cir. 1969) (per curiam); United States v. Pritchard, 413 F.2d 663 (4th Cir.), cert. denied, 396 U.S. 995 (1969); United States v. Henderson, 
The basis-in-fact standard applies, however, only to factual questions. This is clear from Estep's pronouncement that a board's jurisdiction is limited by the statute and the regulations, that only its actions within its jurisdiction are final, and that a registrant can always challenge a board's action on the ground that it is lawless and outside the board's jurisdiction. ${ }^{105}$ Since Estep, moreover, the Court has overturned classifications without deference to the Selective Service System when a board has made a legal error, either by denying procedural rights to a registrant in the course of classifying him, or by misinterpreting the legal requirements for a classification. ${ }^{106}$ Inasmuch as Selective Service proceedings are conducted on a relatively informal basis and board members are chosen as community representatives rather than experts, it is not surprising that courts have undertaken to decide questions of law de novo. ${ }^{107}$

Although courts decide purely legal issues independently of the System, a registrant cannot prevail by showing a legal error on the part of the board unless that error has prejudiced him. ${ }^{108}$ This doctrine poses a potentially bigger hurdle for the registrant than the "harmless error" standard as typically applied. First, some courts require the registrant to show that the error was prejudicial, ${ }^{109}$ rather than placing

411 F.2d 224 (5th Cir. 1969), cert. denied, 399 U.S. 916 (1970). For cases applying it more as the equivalent of a substantial evidence test, see, e.g., Annett v. United States, 205 F.2d 689 (10th Cir. 1953) ; Rautenstrauch v. Secretary of Defense, 313 F. Supp. 170 (W.D. Tex. 1970).

105327 U.S. at 120-21.

106 See Sicurella v. United States, 348 U.S. 385 (1955) (legal interpretation); Simmons v. United States, 348 U.S. 397 (1955) (procedural rights); Gonzales v. United States, 348 U.S. 407 (1955) (procedural rights). Justice Minton would have applied the basis-in-fact test to legal as well as factual questions. He dissented in all three cases on the ground that although the boards involved may have acted mistakenly, their judgment was not so unreasonable as to be arbitrary or capricious. 348 U.S. at $396,406,418$.

107 Cf. Oestereich v. Selective Serv. Local Bd. No. 11, 393 U.S. 233, 242 (1968) (Harlan, J., concurring in the result); McKart v. United States, 395 U.S. 185, 197-99 (1969).

108 See, e.g., United States v. Lawson, 337 F.2d 800 (3d Cir. 1964) ; Pate v. United States, 243 F.2d 99, 104 (5th Cir. 1957). Compare Briggs v. United States, 397 F.2d 370 (9th Cir. 1968) (denial of physical inspection held prejudicial), with Edwards v. United States, 395 F.2d 453, 455-57 (9th Cir.) (no prejudice found), cert. denied, 393 U.S. 845 (1968), and United States ex rel. Lipsitz v. Perez, 372 F.2d 468, 470 (4th Cir.), cert. denied, 389 U.S. 838 (1967) (registrant suffered no "actual" prejudice), and United States v. Bobzien, 306 F. Supp. 1272 (C.D. Cal. 1969) (no prejudice found). Of course, when the error goes to the board's jurisdiction in the strict sense, cf. Estep v. United States, 327 U.S. 114 (1946), prejudice need not be shown; e.g., Adolfson v. Commanding Officer, 3 SEL. SERV. L. REP. 3311 (N.D. Cal. 1970) (no need to show prejudice when board issued induction order to registrant not in its jurisdiction).

109 See, e.g., Adolfson v. Commanding Officer, 3 SeL. Serv. L. Rep. 3311 (N.D. Cal. 1970) (registrant must show prejudice from omission or violation of procedural requisites) (dictum). The same practice prevails in criminal cases that are not of constitutional dimensions; see, e.g., United States v. Lipscomb, 435 F.2d 795, 803 (5th Cir. 1970). 
on the government the burden of proving the error harmless. ${ }^{110}$ Second, some courts hold that classification by the appeal board is independent of the local board so that errors limited to the local board are per se harmless. ${ }^{111}$

\section{The Unreltability of Conscientious Objector DETERMINATIONS}

One firm conclusion can be drawn from experience with the conscientious objector provisions: the results have been unreliable. In part, this is attributable to the difficulties encountered in giving clear definition to the substantive standard. More serious are the seemingly intractable problems involved in attempting to apply the standard within the framework of the Selective Service System.

\section{A. The Standard}

For a time, the standard itself was a matter of considerable dispute. The 1948 version of the Selective Training and Service Act, ${ }^{112}$ like the current statute, said that a person "who, by reason of religious training and belief, is conscientiously opposed to participation in war in any form" would be considered a conscientious objector. ${ }^{113}$ It went on, however, to define religious training and belief:

Religious training and belief in this connection means an individual's belief in a relation to a Supreme Being involving duties superior to those arising from any human relation, but

110 The Supreme Court has held that in criminal cases involving federal constitutional error, the beneficiary of the error must show it harmless beyond a reasonable doubt. Chapman v. California, 386 U.S. 18, 23-24, 26 (1967). In civil cases also, the prevailing rule is that the beneficiary of an error bears the burden of proving it harmless. See F. JaMres, CIVIL Procedure \$11.3, at 531 (1965).

111 See Clay v. United States, 397 F.2d 901, 912-13 (5th Cir. 1968), vacated and rentanded on other grounds sub nom. Giordano v. United States, 394 U.S. 310 (1969); Storey v. United States, 370 F.2d 255, 258-59 (9th Cir. 1966); DeRemer v. United States, 340 F.2d 712, 719 (8th Cir. 1965) (at least where claim was of local board prejudice). Courts differ, however, on which errors are limited to the local board and which also infect the appeal board process. At least one court makes an exception to the inference of appeal board correction when the local board's action "was either so arbitrary or erroneous as to taint the entire procedure." United States ext rel. Khamis v. Resor, 3 SEI. SERv. L. REP. 3295, 3296 (N.D. Ill. 1970). Some courts adopt a test of whether the registrant's claim is the type likely to have been corrected by the appeal board. United States v. Atherton, 430 F.2d 741. (9th Cir. 1970) (distinguishing between claims of local board prejudice and claims where appeal board is likely to be influenced by local board) ; see Caverly v. United States, 429 F.2d 92 (8th Cir. 1970). When the appeal board gives valid reasons for its classification, appeal board correction of local board errors is usually inferred; cf. United States v. Carroll, 398 F.2d 651, 654 n.5 (3d Cir. 1968); United States v. Shevenell, 310 F. Supp. 1069 (D. Me. 1970).

112 This was the popular title of the 1948 draft law. Act of June 24, 1948, ch. 625,62 Stat. 604 .

113 Selective Service Act of $1948 \S 6(j), 62$ Stat. 612, as amended, 50 U.S.C.A. App. $\$ 456(\mathrm{j})$ (Supp. 1972). 
does not include essentially political, sociological, or philosophical views or a merely personal moral code..$^{114}$

One point of confusion was whether the exemption was limited to those with theistic religious beliefs. ${ }^{115}$ This was part of the larger problem of distinguishing between "religious" beliefs and "essentially political, sociological, or philosophical views, or a merely personal moral code." 116

In United States v. Seeger ${ }^{117}$ the Supreme Court held that the "Supreme Being" language of the statutory standard did not require that a man believe in a traditional God to qualify as a conscientious objector. Instead, the Court said that Congress, "in keeping with its long-established policy of not picking and choosing among religious beliefs," 118 had allowed for the exemption of "all sincere religious beliefs which are based upon a power or being, or upon a faith, to which all else is subordinate or upon which all else is ultimately dependent." 119 The Court went on to clarify the line of demarcation between beliefs considered "religious" under the statute and those not deemed religious. Seeger, together with the more recent case of Welsh $v$. United States, ${ }^{120}$ indicates that the primary test of whether a belief is religious within the meaning of the statute is a functional one; the role that the belief plays in the life of the possessor is the central element in deciding whether a registrant's belief is religious "in his own scheme of things." 121 The test the factfinder must apply is "whether a given belief that is sincere and meaningful occupies a place in the life of its possessor parallel to that filled by the orthodox belief in God of one who clearly qualifies for the exemption." ${ }^{122}$ If it does, the source of his

114 Selective Service Act of $1948 \S 6(\mathrm{j}), 62$ Stat. 613, as amended, 50 U.S.C.A. App. $\$ 456(j)$ (Supp. 1972).

115 Compare United States v. Seeger, 380 U.S. 163, 173-180 (1965), with Welsh v. United States, 398 U.S. 333, 348-50 (1970) (Harlan, J., concurring in the result).

116 These problems existed also under the 1940 provision, which was simply: "Nothing contained in this Act shall be construed to require any person to be subject to combatant training and service in the land or naval forces of the United States who, by reason of religious training and belief, is conscientiously opposed to participation in war in any form." Selective Training and Service Act of $1940 \$ 5(\mathrm{~g})$, 54 Stat. 889. Compare United States ex rel. Reel v. Badt, 141 F.2d 845 (2d Cir. 1944), and Uंnited States v. Kauten, 133 F.2d 703 (2d Cir. 1943), and United States ex rel. Phillips v. Downer, 135 F.2d 521 (2d Cir. 1943), with Berman v. United States, 156 F.2d 377 (9th Cir. 1946) (en banc).

117380 U.S. 163 (1965).

$118 \mathrm{Id}$. at 175 .

$119 \mathrm{Id}$. at 176.

120398 U.S. 333 (1970).

121380 U.S. at 184-85.

122 Id. at 166. See id. at 184; Welsh v. United States, 398 U.S. at 339-40. 
belief-whether it is internally derived or externally compelled ${ }^{123}$-is immaterial. ${ }^{124}$ Nor need it derive from the teachings of any religious group, as opposed to the registrant's own reading or contemplation. ${ }^{125}$

There is, however, a substantive as well as a functional dimension to the test whether a belief qualifies. A purely pragmatic belief-for example, a belief that the registrant should avoid endangering his lifecannot qualify even if it occupies a central place in the registrant's life and scheme of values. Similarly, a belief that war is unwise as a matter of policy will not suffice. The objection must be conscientious. Although it may be "founded to a substantial extent upon considerations of public policy," it may not rest "solely upon considerations of policy, pragmatism, or expediency." 128 It must have some "moral, ethical, or religious" content in order to qualify. ${ }^{127}$

$W$ elsh and Seeger were concerned with the 1948 statute. Congress amended the statute in 1967, excluding the clause defining religious training and belief as "an individual's belief in relation to a Supreme Being involving duties superior to those arising from any human relation." ${ }^{228}$ Congress' purpose in making this change is quite unclear. While the amendment would seem most plausibly to show acceptance of the Seeger holding that theistic belief is not required, the legislative history indicates that some members of Congress believed they could avoid that holding by abandoning the Supreme Being language. ${ }^{129}$ Apparently they were influenced by language in Seeger suggesting that Congress' use of the term "Supreme Being," rather than "God," showed the exemption embraced a wide spectrum of religious belief. ${ }^{130}$

123 The Government in Welsh conceded that the registrant's belief was held with the strength of traditional religious convictions but claimed that, even after Seeger, conscientious objector status could be denied to one whose beliefs had no religious basis. 398 U.S. at 337-38. The Court held, however, that Welsh's beliefs qualified him for conscientious objector status.

124 United States v. Seeger, 380 U.S. 163, 186 (1965).

${ }^{125}$ The Court in Welsh said that the "sincere and meaningful beliefs that prompt the registrant's objection to all wars need not be confined in either source or content to traditional or parochial concepts of religion." 398 U.S. at 339 ; see 380 U.S. at 184-85. Neither Seeger nor. Welsh belonged to a religious group or adhered to the teaching of any organized religion when they applied for conscientious objector status, yet both their claims were upheld by the Supreme Court.

126398 U.S. at $342-43$. See 380 U.S. at 173 (those objecting "on the basis of essentially political, sociological or economic considerations" excluded).

127398 U.S. at 342. See id. at 339-40.

128 See note 5 sipra. Although the Supreme Court decided Welsh subsequent to the amendment, it was the 1948 version of the Act that the Court was interpreting; Welsh had been convicted of refusing to submit to induction in 1966, prior to the amendment.

129 See H.R. REP. No. 267, 90th Cong., 1st Sess. 31 (1967) ; H.R. REP. No. 346, 90th Cong., 1st Sess. 15-16 (1967) ; 113 CoNG. Rec. 15,428-29' (1967) (remarks of Senator Edward Kennedy). But see id. 14,098, 14,119-20 (remarks of Congressmen Edwards and Kastenmeier); id. 15,428 (remarks of Senator Russell). 130 See 380 U.S. at 174-76. 
It does not seem likely, however, that the statute will be read more narrowly without the Supreme Being language than it was with it. The issue for the Court in Seeger was whether the reference to a Supreme Being narrowed the meaning of "religious training and belief" or left it unaltered. The Court decided that the Supreme Being language did not change the preexisting test of "religious training and belief"; it did not decide that the Supreme Being language enlarged the definition of religion or that the definition would be any narrower in its absence. ${ }^{131}$

It seems then that the Welsh-Seeger test of who is sufficiently religious remains viable. ${ }^{132}$ Accordingly, a draft board's duty in passing on a conscientious objector claim is to decide whether a registrant's objection is sincere, whether it is based on religious training and belief within the meaning of Welsh and Seeger, and whether it runs to participation in all wars. ${ }^{133}$

\section{B. Application of the Standard}

Even if the standard is properly understood, there remains for those who find the facts the elusive task of probing the registrant's state of mind. Part of the problem may lie in the nature of the factfinder. Board members are not sympathetic to conscientious objector claims. ${ }^{134}$

131 See id. at $165,173,176$.

132 As indicated, note 6 supra, the test stated in Mr. Justice Black's opinion in Welsh was adopted by the Court, although there is no opinion for the Court. Mr. Justice Harlan, who had joined the Court's opinion in Seeger, had second thoughts about that opinion as a matter of statutory construction, as well as disagreeing with the statutory construction in Welsh. 398 U.S. at 344 (Harlan, J., concurring in the result). He thought that Congress had intended to exempt only persons with theistic religious beliefs. It did not intend to exempt adherents of nontheistic religions, $i d$. at $348-50$, nor did it intend to exempt those whose beliefs were not acquired through "religion" in the conventional sense, $i d$. at 351-54. Justice Harlan thought, however, that the statutory provision as properly construed violated the religion clauses of the first amendment, id. at 356-61. He believed that when a statutory provision is unconstitutional because of underinclusion, nullification of the provision is not the only possible remedy. The Court may instead, if it deems it more appropriate, extend the statute's coverage to include more persons. Id. at 361-67. But see $i d$. at 367-69 (White, J., dissenting). It was on this reasoning that Justice Harlan "adopt[ed] the test announced by MR. JUSTICE BLACK, not as a matter of statutory construction, but as the touchstone for salvaging a congressional policy of long standing that would otherwise have to be nullified." Id. at 345 (Harlan, J., concurring in the result).

133 There are difficulties also in deciding whether a particular registrant's objection runs to all wars. See note 302 infra.

$134 \mathrm{~J}$. Davis \& $\mathrm{K}$. Dolbeare, Little Groups of Neighbors 92, table 4.2, 108 (1968); Rabin, $A$ Strange Brand of Selectivity: Administrative Law Perspectives on the Processing of Registrants in the Selective Service System, 17 U.C.L.A.L. Rev. 1005,1019 (1970). Only 5\% of the board members polled in a Wisconsin study thought it was very important to defer conscientious objectors and $55 \%$ said that conscientious objectors should not be deferred at all. Davis \& Dolbeare, $A$ Social Profile of Local Draft Board Members: The Case of Wisconsin, in Selectrve Service and AMERICAN SocIEry 53, 73-74 (R. Little ed. 1969) [hereinafter cited as A Social Profile]. See G. Wamsley, Selective Service \& A Changing America 146 (1969) (suggesting local board hostility to "unconventional" claimants).

Board members also have peculiarly middle class values. The predominant middle class composition, see note 229 infra \& accompanying text, of the local boards 
Many are veterans ${ }^{135}$ and they frequently belong to veterans' organizations. ${ }^{136}$ All are persons whose sense of duty has led them to volunteer their time ${ }^{137}$ to the operation of the system of military conscription, ${ }^{138}$ while the conscientious objector's claim for exemption is based on a rejection of the military system itself. Prior to the recent statutory amendments not only did the typical board have a bias, but it also was an interested party. The board's basic responsibility was to fill a monthly quota of men available for service; ${ }^{139}$ when it allowed a man to avoid military service, it had to find another to replace him. A I-A-O classification leading to noncombatant service did count toward

can be explained partly by the fact that voluntary and uncompensated service on the draft board is the sort of civic duty which members of the middle class are accustomed to performing. Board members are frequent holders of other civicly oriented nonpartisan offices. A 1966 study of local board members in Wisconsin revealed, for example, that $26 \%$ of the members had held a position on their local school boards. J. Davis \& K. Dolbeare, supra at 65-71; Wamsley, Decision-Making in Local Boards: $A$ Case Study, in Selective Service and AMERICAN Society 83, 93-94 (R. Little ed. 1969) [hereinafter cited as Decision-Making].

135 A 1966 study reported that almost two-thirds of board members were veterans. J. Davis \& $\mathrm{K}$. Dolbeare, supra note 134 , at 57 . National Advisory Commission on Selective Service, In Pursuit of Eouity: Who Serves When Not Art Serve? 19 (1967) [hereinafter cited as Marshall Commission ReporT]; G. WaMrsLey, supra note 134 , at 94 . Davis \& Dolbeare put together statistics to conclude that the average board in 1966 had three veterans, one of whom was a veteran of World War I. J. Davis \& $K$. Dolbeare, supra at 57.

At least in several instances during World War II the selection of veterans for service on the local boards was a deliberate statewide policy. A State Director of Selective Service of a midwestern state explained his preference for veterans in the following manner:

. . if a majority of the local board members were veterans, because of their previous service and activities in various veterans' organizations, they would have an understanding of service to the nation and a patriotic desire to do the best possible for their country.

In the appointment of members of local boards, lists were obtained from the various veterans' organizations, principally the American Legion, Veterans of Foreign Wars, and the United Spanish War Veterans, as well as recommendations from civic groups such as Kiwanis, Rotary, Lions, Chamber of Commerce, and various labor groups, both CIO and A. F. of L. From these lists men were selected and appointed as members of the individual local boards, and boards of appeal throughout the state.

Selective Service System, Organization and Administration of the System 191 (Special Monograph No. 3, 1951). For a discussion of the reliance placed on veterans' organizations in the initial selection of board members after passage of the 1940 draft law, see G. WAMSLEY, supra at 128.

$13646 \%$ of Wisconsin's local board members belong to veterans' organizations as compared to $6 \%$ for the United States adult population. J. DAVIS \& K. DOLBEARE, supra note 134 , at 68 , table 3.5 . The comparatively high proportion of members belonging to such organizations indicates a continuing military connection and a high regard for conventional patriotism on their part. (1972).

137 Board members are not compensated for their services. 32 C.F.R. $\$ 1603.3$

138 Rabin, supra note 134, at 1019. But see Evening Bulletin (Philadelphia), Feb. 3, 1972, at 48, col. 1, reporting the request of the Pennsylvania State Director to remove from a local draft board a 21 -year-old member who had joined "to make sure the views of people of [his] age [were] present in the board meetings" and who followed a policy of granting deferments upon request because he was "against making people go to war if they don't want to."

13032 C.F.R. §1631.6(a) (1972). 
fulfiliment of the quota, but a I-O classification did not. ${ }^{140}$ Section 5 (d) of the new statute, when read in conjunction with an executive order issued in July $1971,{ }^{141}$ alters this situation by establishing a uniform national call. Men holding lottery numbers up to a specified ceiling, periodically announced by the Director of Selective Service, are vulnerable to being called, regardless of how many registrants falling within this category a particular board might have.

If draft boards were purely neutral factfinders, however, they would still have difficulty passing reliable judgments upon conscientious objector claims. The boards, as earlier observed, are "not composed of experts, real or purported, but of citizens of the neighborhood." 142 They may not understand the applicable legal rules and may be confounded by the lengthy and sophisticated statements some registrants submit to explain their beliefs, particularly registrants without traditional religious affiliations. ${ }^{143}$

Problems more basic than the nature of the boards are that often there is little evidence available to substantiate or disprove the registrant's asserted belief, and that even when there is evidence to be found, there is little likelihood that current factfinding procedures will bring it to light. In the past, a local board typically utilized only the following sources of information when it passed on the merits of a conscientious objector application in the first instance: the registrant's statements made in his Form 150, his other correspondence with the board, and statements submitted by third persons whom the registrant had requested to support his claim. Under the recent amendments the same should be true except for those registrants who request that their personal meeting with the board ${ }^{144}$ be held before the initial classification instead of after it. ${ }^{145}$

$140 I d$.

141 Exec. Order No. 11,606, 3 C.F.R. 179 (1972).

142 Ex parte Stanziale, 138 F.2d 312, 314 (3d Cir.), cert. denied, 320 U.S. 797 (1943).

143 Board members do not develop skills because of the occasional nature of their job and the small percentage of conscientious objector cases. See Rabin, supra note 134, at 1018; Rabin, supra note 36, at 650 . Board members are often unaware of existing regulations, $J$. Davis \& $\mathrm{K}$. DolbEARE, supra note 134 , at 80 , and controlling precedents. Rabin, sicpra note 36, at 670 . The System's tardiness in revising Form 150 following the Seeger decision served to exacerbate these difficulties. Hearings on Selective Service \& Military Compensation Before the Senate Comm. on Armed Services, 92d Cong., 1st Sess. 417 (1971) (statement of Mr. Neier, Executive Director, ACLU).

144 For a discussion of the relevance to this problem of the personal appearance before the board, see text accompanying notes $180-94$ infra.

145 Under the new regulations, registrants who claim conscientious objector status have a right to meet personally with the board either before or after the board's initial classification. 37 Fed. Reg. 5122 (1972) (to be codified at 32 C.F.R. $\$ 1624.1)$. Other registrants' right to a personal appearance comes into play only after the board has initially denied their requested deferment or exemption. Id. 
Prior to the 1967 amendment of the draft law, it was not critical that frequently the only evidence considered by the board was that submitted by the registrant. Special procedures were available at a subsequent stage to fill the gap. When a registrant appealed a denial of a conscientious objector claim, the appeal board, on the basis of his file, would make a determination whether the local board's action was correct. If the appeal board also ruled against the registrant, the case was referred to the Department of Justice for investigation and recommendation. ${ }^{146}$ The Department of Justice procedure started with an FBI investigation, which ordinarily consisted of interviews with a wide range of persons who had had contact with the registrant. ${ }^{147}$ After the investigation was completed, the registrant, provided with a written summary of the evidence in the FBI report, ${ }^{148}$ appeared before a hearing officer, ${ }^{149}$ where he could contest the information in the report and produce witnesses to support his claim. ${ }^{150}$ The registrant could be represented by counsel at this hearing. ${ }^{151}$

The hearing officer was generally a private attorney who had volunteered to perform this function without compensation. ${ }^{152}$ After the hearing, he reported his findings and conclusions to the Department, recommending for or against a grant of conscientious objector status.

Despite these provisions a board may always request a registrant to appear before it in the exercise of its investigative powers. 32 C.F.R. $\$ 1621.15$ (1972) (providing subpoena powers). But such an interview on the initiative of the board will not displace the registrant's right to have a personal appearance at his request.

Prior to the recent regulations, conscientious objectors, like other registrants, had a right to a personal appearance on their request only after they were initially classified. 32 C.F.R. \$1624.1(a) (1972). The period from mid-1968 to mid-1970 is an exception, however. During that time local boards were instructed to hold a preclassification interview, apart from any request on the part of a registrant, with registrants claiming to be conscientious objectors to whom boards felt they could not grant conscientious objector status. Local Board Mem. No. 41, Sel. SERv. L. Rep. 2174 (as amended, 1968) (rescinded, 1970). That interview did not take the place of the post-classification personal appearance. Id.

146 The 1940 statute first provided for the Department of Justice procedure. It directed that the Department should, after "appropriate inquiry" hold a hearing "with respect to the character and good faith of the objections of the person concerned." Selective Training and Service Act of 1940, ch. 720, $\$ 5(\mathrm{~g}), 54$ Stat. 889 . The provision was in effect until 1967. Military Selective Service Act of 1967, Pub. L. No. $90-40, \S 1(7), 81$ Stat. 104.

147 Reisner, supra note 55, at 687 n.5; Smith \& Bell, The Conscientions Objector Progranl-A Search for Sincerity, 19 U. PITT. L. Rev. 695, 701 (1958).

148 See Simmons v. United States, 348 U.S. 397 (1955); Smith \& Bell, supra note 147, at 701-02; cf. United States v. Nugent, 346 U.S. 1 (1953).

149 Selective Training and Service Act of 1940, ch. 720, §5(g), 54 Stat. 889.

150 Smith \& Bell, supra note 147, at 702.

151 Office of the Attorney General, Mem. No. 41 (revised), $\$ 104.1$ (Apr. 2, 1956). The attorney could not, however, "object to any question or make any argument concerning any phase of the proceeding," $i d$. $\$ 104.5$, which was meant to be conducted in an "informal, non-technical and flexible manner," $i d$. $\$ 104.1$.

152 Reisner, supra note 55, at 688; White, Processing Conscientious Objector Claims: A Constitutional Inquiry, 56 CALIF. L. REv. 652, 654 (1968). 
The hearing officer's recommendation did not bind the Department. ${ }^{153}$ Nor did the Department's subsequent recommendation and advisory opinion-based on the registrant's Selective Service file, the FBI investigation, and the hearing officer's report ${ }^{154}$ _-bind the appeal board, ${ }^{155}$ which again passed on the registrant's classification. ${ }^{156}$ It has been estimated, however, that the board did follow the Department's recommendation in ninety to ninety-five percent of the cases. ${ }^{157}$ Moreover, the Department's recommendation was favorable to the registrant in more than seventy percent of all cases. ${ }^{158}$

In 1967, Congress abolished the Department of Justice procedure. $^{159}$ With larger draft calls, and the consequent increase in appeals from unfavorable classifications, the Department was unable to keep abreast of the cases, and Congress became concerned that the procedure provided an attractive delaying tactic that could be used even by those with no hope of receiving conscientious objector status. ${ }^{160}$

During the period when this procedure existed, it appears that many local boards routinely denied all but the most clear-cut conscientious objector claims because they considered the evidence they had inadequate for making reliable determinations. ${ }^{161}$ As observed above, only a denial would lead to departmental investigation and recommendation. Similarly, the appeal board was likely to deny a claim initially in order to elicit more evidence. ${ }^{162}$ With the abolition of the procedure, however, the only evidence available at any stage with which to judge the validity of a registrant's claim is typically the evidence

153 Rabin, supra note 36 , at 680 , reports that the Chief of the Conscientious Objector Section of the Department has estimated that the Department followed the hearing officer's recommendation in approximately $75 \%$ of the cases.

154 Smith \& Bell, supra note 147 , at 702 .

155 Exec. Order No. 10,714, §1626.25, 22 Fed. Reg. 4273, 4275 (1957) (rescinded, Exec. Order No. 11,360, 32 Fed. Reg. 9787, 9792 (1967)).

156 Selective Service Act of 1948, ch. $625, \S 6(j), 62$ Stat. 613, as anended, 50 U.S.C.A. App. $\$ 456(j)$ (Supp. 1972); Exec. Order No. 10,714, §1626.25(e), 22 Fed. Reg. 4273, 4275 (1957) (rescinded, Exec. Order No. 11,360, 32 Fed. Reg. 9787, 9792 (1967)).

157 Smith \& Bell, supra note 147, at 702 (90-95\%); Gonzales v. United States, 364 U.S. 59, 72 (1960) (over 90\%).

158 Estimate of the Conscientious Objector Section of the Department of Justice, reported in Reisner, supra note 55, at 687. Smith \& Bell, supra note 147, at 702, reports that in $80 \%$ of the cases approval of the claim was recommended. The disparity may be due to a lower percentage of favorable recommendations during the final years of the Department procedure, when many more registrants were drafted and challenges to local board classifications markedly increased. See Reisner, supra at 688.

15950 U.S.C. ApP. $\$ 456(\mathrm{j})$ (1964), as amended by Pub. L. No. 90-40, §1(7), 81 Stat. 104 (1967).

160 See Civilian Advisory Panel on Mitrtary Manpower Procurement, 90th Cong., 1st Sess., Report to the House Comm. on Armed Services (Comm. Print 1967); H.R. REP. No. 267, 90th Cong., 1st Sess. 31 (1967) ; H.R. REP. No. 346, 90th Cong., 1st Sess. 15 (1967).

161 See Rabin, supra note 36 , at 668-70.

162 See id. 674; Smith \& Bell, supra note 147 , at 700. 
before the local board; no evidence will be gathered later to correct an erroneous decision at the initial level, ${ }^{163}$ and local boards themselves have no more evidence than that which they often deemed inadequate in the past. ${ }^{164}$

Although boards have power to conduct their own investigations, ${ }^{165}$ they rarely do so. ${ }^{160}$ Long accustomed to relying solely on evidence

163 Since the 1971 amendments there is one exception: Appeal boards now grant personal appearances, 37 Fed. Reg. 5123 (1972) (to be codified at 32 C.F.R. $\$ 1626.3(a))$, which could produce additional evidence. That personal appearance is likely to be duplicative of the personal appearance before the local board, however, and all evidence before either board in the usual case still comes from the registrant and sources that he provides. Systematic investigation on the part of the government is utterly lacking.

164 The unofficial transcript of the personal appearance in the case of O'Brien v. Resor, 423 F.2d 594, 598-99 (4th Cir. 1970), suggests that some local boards may have continued to defer to the appellate procedure after the reason for such deference disappeared. O'Brien's second personal appearance was on November 14, 1967; the amended Act was approved on June 13, of that year, and the Department of Justice procedures were therefore not utilized in his case. The transcript reads (emphasis in original) :

Mr. Ballard: Is there something you wanted to add to your case?

Me: No. I only wanted to discuss my classification of I-A so that I might answer any of your questions and doubts.

Mr. Ballard: We don't actually have any questions. We studied your file and feel we can't classify you I-O.

Me: Could you tell me why you made this decision. Is it because you doubt some of my answers or convictions?

Mr. Ballard: We don't actually doubt your beliefs-it's just that you never applied before.

Me: I realize I never applied before but according to the regulations there isn't really any time stipulated for an individual to register as a conscientious objector. According to the Supreme Court, it's simply whether or not an individual is sincere and lives according to his beliefs in a Supreme Being.

Mr. Ballard: Well, there are many regulations concerning this and it's just a hair-line border between them. We just don't feel we can give you the classification.

Me: If you've read my material, you've seen I have lived according to my convictions over the years. There are letters from friends who have known me over the past four years, my roommate, professors, a minister, and my brothers, who I'm very close to and who know my feelings. All of these people have written because they feel I am sincere in my beliefs.

Mr. Ballard: Yes, we have read the letters and ze believe you are sincere. All of us as Christians don't believe in killing and when the time comes we must think about it.

Me: Then it's just that I applied late.

Mr. Ballard: No, not really, it's just that you should appeal to the Board of Appeals.

Older Man: Yes, I think it would be better for you if you appeal it. The board seems to have more time for things like this. They have the time to read your material and won't make any hasty decisions. Yes, I think it's best to appeal it.

Me: But if you gentlemen feel I'm sincere why can't you classify me as a conscientious objector?

Mr. Ballard: We certainly feel you're sincere. You certainly wouldn't drive all the way from Baltimore on just a hunch. Why it's not just the expense there's a lot of time involved.

165 See text accompanying notes 43-45 supra.

166 Reisner, supra note 55 , at 710 . 
submitted to them, their failure to change their approach since 1967 is not surprising. The nonprofessional, volunteer nature of draft boards also makes it difficult for them to change their ways. Board members are unpaid ${ }^{167}$ and typically spend only one or two evenings a month at the job. ${ }^{168}$ To have added the responsibility for investigating claims to the heavy caseload the Vietnam conflict has entailed would have involved a commitment of time that draft boards are unwilling to give.

For boards to rest their decisions solely on registrants' evidence creates a troublesome situation. At least those registrants whose biographical data presented in their Form 100 do not belie their claims, and who have been advised by counsel from the time they first registered for the draft should, under that procedure, receive classification as conscientious objectors, whether or not their claims are genuine. Even registrants who seek conscientious objector status after their initial registration should, with competent advice, be able to present papers showing a prima facie case and nothing that casts doubt upon the claim. If then the registrant's evidence alone can induce or compel the board to grant a claim, claims can easily be fabricated, and a man's chances of success within the Selective Service System will depend less on whether he is a sincere conscientious objector than on the care he takes in supplying data to his board.

Boards may respond by denying claims because they distrust the registrant, even though no evidence supporting disbelief appears in the record. They may suspect that evidence supporting the claim is fabricated or that full investigation might produce contradictory evidence, and they may justify denying a claim on simple disbelief since the registrant bears the burden of proving that he is entitled to the exemption. One can have little confidence in a selection of which claims to disbelieve, however, when nothing in the file provides grounds for doubting sincerity; it seems inevitable that genuine claims would be denied along with false ones, and that some false claims would continue to be granted. ${ }^{169}$ To empower boards to deny claims on the basis of

16732 C.F.R. $\$ 1603.3$ (1972).

168 Rabin, supra note 36 , at $649-50$.

169 Professor Ralph Reisner conducted a study of the bases for classification decisions when the Department of Justice procedure was in effect, see Reisner, supra note 55 , at $710 \mathrm{n} .139$, and concluded that the ultimate decision as to sincerity at that time rarely rested on the applicant's own statements or such an elusive factor as his demeanor during his brief personal appearance before the local board or the hearing officer. Instead a registrant's inability to explain evidence that was revealed by the FBI investigation and was contradictory to his claim was, according to Professor Reisner, the most frequent reason for ultimate denial on the ground of insincerity. Id. 710 .

Under current procedures the registrant will not often be confronted with the problem of having to explain adverse information, because typically no adverse information will be produced. But those registrants for whom, if an investigation were 
mere disbelief would, moreover, make their discretion in granting or rejecting claims unlimited and utterly unreviewable, a result particularly troublesome when the board's impartiality is questionable. ${ }^{170}$

In a somewhat different context, the Supreme Court has held that a board is not free to reject a registrant's claim when nothing in his file supports the rejection. In Dickinson v. United States, ${ }^{171}$ the Court reversed the conviction of a man who had been denied a ministerial exemption by the Selective Service System. The board's apparent ground was disbelief of Dickinson's evidence, but there was nothing in his file impeaching or contradicting his claim. The Court held that "when the uncontroverted evidence supporting a registrant's claim places him prima facie within the statutory exemption, dismissal of the claim solely on the basis of suspicion and speculation is both contrary to the spirit of the Act and foreign to our concepts of justice." 172 Its ruling, it said, was consistent with the basis-in-fact test for "if the facts are disputed the board bears the ultimate responsibility for resolving the conflict-the courts will not interfere." ${ }^{173}$ Under the basis-in-fact test "the task of the courts . . . is to search the record for some affirmative evidence to support the board's overt or implicit finding that a registrant has not painted a complete or accurate picture of his activities." 174 If, however, there is no proof "incompatible with the registrant's proof of exemption," boards must utilize their investigatory powers to produce conflicting evidence before they can be upheld in denying the claim. ${ }^{175}$

conducted, no adverse information would be uncovered, or those who would be able to explain away any negative findings, suffer from the cloud of suspicion that hangs over all claims because they are not checked out.

A later study by the same author compares present appeal board determinations with pre-1967 ones. Professor Reisner concludes that "the critical difference : . . lies in the greater use by appeal boards of a small number of absolute criteria by which eligibility is judged. The decisions rendered by the Justice Department appear to have been predicated on a less absolute, more individual appraisal of the applicant's beliefs." Reisner, supra note 7 , at 541 .

170 See notes $134-41$ supra \& accompanying text.

171346 U.S. 389 (1953).

$172 I d$. at 397.

$173 I d$. at 396.

174 Id.

175 Id. at 396-97.

The dissenters in Dickinson claimed that the Court had abandoned the basis-infact test by "examin[ing] and weigh [ing] . . . purely factual determinations," id. at 400 (Jackson, J., dissenting) :

It will not do for the Court . . . to say on the one hand that the board's action is not subject to "the customary scope of judicial review" and that "the courts are not to weigh the evidence," and then on the other to strike down a classification because no affirmative evidence supporting the board's conclusion appears in the record. Under today's decision, it is not sufficient that the board disbelieve the registrant. The board must find and record affirmative evidence that he has misrepresented his case-evidence which is 
The rule of Dickinson applies somewhat differently to conscientious objector cases. Two years after Dickinson, the registrant in Witmer $v$. United States ${ }^{176}$ argued to the Supreme Court that the Selective Service System erred in denying his conscientious objector claim when he had made a prima facie case of conscientious objector status and his file contained no evidence incompatible with the claim. The Court ruled that a board could legitimately deny the claim without any evidence positively inconsistent with conscientious objector status. It distinguished the ministerial exemption at issue in Dickinson on the ground

then put to the test of substantiality by the courts. In short, the board must build a record.

Id. at 399 .

Professor Kenneth Culp Davis also has claimed that the Court's refusal to allow the board to find against the party having the burden of proof on the ground that it disbelieves his evidence is inconsistent with the basis-in-fact test that the Court said it espoused. $4 \mathrm{~K}$. DavIs, supra note $102, \$ 29.07$, at 150 .

An analogous issue in a civil trial is whether a judge should be permitted to direct a verdict for the party having the burden of proof. Courts disagree on whether it is ever permissible to direct a verdict when a plaintiff offers evidence that, if believed, would entitle him to a verdict, and the defendant offers no contradictory evidence. Some say that a verdict cannot be directed for the plaintiff because the jury must pass upon whether he is to be believed and what inferences to draw from his testimony. See, e.g., Alexander v. Tingle, 181 Md. 464, 30 A.2d 737 (1943); Woodin v. Durfee, 46 Mich. 424, 9 N.W. 457 (1881). Others hold that the judge may direct a verdict for the party bearing the burden of proof. He should do so in those cases where the proponent has made a prima facie case and there is nothing in the evidence that provides the factfinder with a reasonable basis for disbelieving the proponent's evidence. He may direct a verdict even if persons supplying the evidence have an interest in the outcome, for the fact that they are interested does not by itself provide a basis for discrediting their testimony:

A jury has no greater or better right to act arbitrarily or unreasonably in forming a judgment or opinion as to whether or not a witness speaks the truth than it has to act unreasonably in arriving at any other opinion or conclusion.

And there is no general rule "that the mere fact that a witness is interested in the matter in controversy, in and of itself, without regard to other circumstances of the case, makes it reasonable to disbelieve . . his testimony ...." Jerke v. Delmont

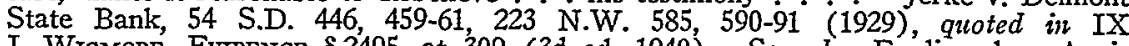
J. Wigmore, EviDENCE $\$ 2495$, at 309 (3d ed. 1940). See also Ferdinand v. Agricultural Ins. Co., 22 N.J. 482, 126 A.2d 323 (1956).

Wigmore considers the latter approach the better rule, IX J. WIGMoRE, supra $\$ 2495$, at 306 , and both he and James report it as the prevailing view. F. JANSES, supra note 110, $\$ 7.11$, at 279 ; IX J. WIGMORE, supra $\$ 2495$, at 305 . It is the counterpart of the Dickinson rule in draft board cases except that under Dickinson it is not a rule of reason, based on all the facts and circumstances of the particular case, that determines whether the factfinder can disbelieve the registrant because of his interest in the outcome; instead there is a per se rule that a board cannot discredit the registrant unless it finds something else in the evidence to cast doubt on his veracity. This difference may be explained in part because in draft board procedures the board occupies the roles both of factfinder and judge; no case can be kept from disposition by the factfinder in the absence of a per se rule, for, at this stage of the proceedings, there is no separate third body to determine how a rule of reason applies to the particular case. Moreover, that boards are likely to have to participate in gathering facts adverse to the registrant, if any are to be gathered, presents a special danger, without a counterpart in civil cases: that the factgathering process will be short-circuited if the factfinder is permitted to rule against the registrant because of a disbelief that lacks a basis in any evidence that has been gathered. Under the quota system the danger was accentuated because the boards, unlike juries,
had an interest in the outcome.

176348 U.S. 375 (1955). 
that good faith was irrelevant to that exemption, which required only a showing of totally objective facts-that the registrant's regular vocation was preaching and teaching religion. Conscientious objector cases, by contrast, always involve the subjective issue of the registrant's sincerity. ${ }^{177}$

Witmer added, however, that Selective Service authorities may not rule against a registrant "solely on the basis of suspicion and speculation" in conscientious objector cases any more than in others. A denial based on insincerity can be sustained only if there is something in the registrant's file that casts doubt on the registrant's veracity. ${ }^{178}$ Witmer's conviction was in fact sustained on the ground that his statements to the board justified an inference of insincerity. ${ }^{179}$

As noted above, in many cases local boards meet with the registrant himself. As a result of the 1971 amendments, the same is now likely to be true of appeal boards as wel1. ${ }^{180}$ While a registrant is in full control of the evidence he presents to his board in writing, and can draft it so that it clearly supports his position, he obviously cannot predict, much less control, the board's assessment of his demeanor at a personal appearance. If the board is entitled to reject a claim because it concludes from its observations of the registrant that he is not telling the truth, the registrant cannot be assured of success by the simple expedient of filing a paper claim which is free of inconsistency. ${ }^{181}$

While there is an absence of square holdings on the subject, there are suggestions in the case law that a board may properly disbelieve a registrant because of his demeanor and reject his claim for that reason alone. In Witmer, for example, the Court noted that "Witmer stated his beliefs with apparent sincerity" 182 and that there was "no indication anywhere in the record that his demeanor appeared shifty or evasive or

$177 \mathrm{Id}$. at 381. Cf. Dickinson v. United States, 346 U.S. at 393 n.5.

178348 U.S. at $381-82$.

179 Prior to claiming conscientious objector status Witmer had claimed exemptions as a farmer and as a minister, both of which claims had been frivolous; he had made inconsistent statements about whether his beliefs permitted him to contribute to the war effort in any capacity; and he had not adduced any evidence of a prior expression of his conscientious opposition to participation in war. Id. at 382-83.

180 See 50 U.S.C.A. ApP. $\$ 471 a(b)$ (1) (Supp. 1972).

$181 \mathrm{~A}$ registrant might benefit, if this is the rule, by avoiding an appearance before the board. Bypassing a personal appearance before the local board by immediate appeal is not considered a failure to exhaust administrative remedies that bars later judicial review. (This, at least, is the position of commentators, J. GRIFfiths, The Draft Law 41 (2d ed. 1968); Sel. Serv. I. Rep. Practice Manual T2411 (1968), but there is no definitive judicial decision on the issue.) A board can deprive a registrant of this stratagem by requiring him to appear before it, see McGee v. United States, 402 U.S. 479 (1971); note 145 supra, but it may be doubted whether the overburdened boards will be that farsighted in very many instances.

182348 U.S. at 382. 
that his appearance was one of unreliability . . . "183 For this reason, it explained, it was necessary, in order to sustain the conviction, to find inferences of insincerity in the written statements Witmer had presented to the board.

This language implies, however, that the mere fact that the registrant met personally with the board would not suffice as a basis in fact for an unfavorable classification. When nothing in the record is unfavorable to a registrant, an adverse classification will not be sustained simply because, in its meeting with the registrant, the board might have discredited his claim because of his demeanor. Such a finding on the part of the board will not be presumed unless the board records its unfavorable impressions in the registrant's file. A contrary rule would undermine Dickinson's holding-that disbelief should not be inferred in the absence of evidence to support the inference-in all cases where a registrant appeared before his board. Witmer permits that result only where the board makes an adverse notation concerning the registrant's demeanor, ${ }^{184}$

Allowing a board to reject a claim by making an adverse finding concerning the registrant's demeanor does provide a means of rejecting claims that are perfect on paper but may in fact be insincere. Yet there is little basis for confidence that the claims the board rejects on the basis of demeanor will be those that in fact are insincerely made. The typical hearing before the draft board does not provide a reliable basis for separating the genuine claims from the contrived ones. Protections which are deemed to enhance the reliability of the factfinding process in judicial proceedings are absent: for example, a public forum, ${ }^{185}$ the right to confront and cross-examine adverse witnesses, ${ }^{186}$ and the right to counsel. ${ }^{187}$ Inarticulate or poorly-educated registrants may be particularly prejudiced. ${ }^{188}$ Prior to the 1971 amendments, the typical per-

$183 I d$.

184 Other cases indicating that a board may deny on the basis of demeanor evidence are: United States v. Washington, 392 F.2d 37, 39 (6th Cir. 1968); United States v. Corliss, 280 F.2d 808, 814-16 (2d Cir. 1960) (conviction affirmed on basis of demeanor notation in record); Parr v. United States, 272 F.2d 416, 419 (9th Cir. 1959) (conviction reversed in absence of demeanor notation); Pitts v. United States, 217 F.2d 590 (9th Cir. 1954) (same); Campbell v. United States, 221 F.2d 454, 457-58 (4th Cir. 1955). But cf. Batterton v. United States, 260 F.2d 233, 236-37 (8th Cir. 1958),

185 See In re Oliver, 333 U.S. 257, 266-72 (1948); People v. Jelke, 308 N.Y. 56, 61-62, 65, 123 N.E.2d $769,771-73$ (1954).

186 See Pointer v. Texas, 380 U.S. 400, 404-06 (1965); Greene v. McElroy, 360 U.S. 474, 496-97 (1959); 1 K. DAVIS, supra note 102, \$7.05; V J. WIGMIORE, supra note $175, \S 1367$.

187 See, e.g., Gideon v. Wainwright, 372 U.S. 335 (1963).

188 The lack of procedural safeguards before the local board may be more critical now than it was prior to 1967 . Previously the registrant who was unsuccessful before his local board had an opportunity later for a hearing at which he could be represented by counsel, was furnished a resumé of evidence that the FBI had 
sonal appearance before a local draft board lasted for only about ten minutes. ${ }^{189}$ The regulations now suggest fifteen minutes as normal, ${ }^{190}$ but that period is to include the three witnesses the registrant now may present. Nervousness caused by the seriousness of the occasion, rather than the lack of a genuine claim, could well explain any evasiveness on the part of the registrant that occurs, and such a short interview cannot usually provide a reliable basis for distinguishing one from the other. ${ }^{191}$ The lack of time allowed for the personal appearance is probably due, in large part, to the volunteer nature of draft boards. ${ }^{102}$ Time pressures may also prevent board members from making a thorough study of the registrant's file. A board unfamiliar with a registrant's claim cannot maximize the utility of its hearing with the registrant to clarify or expose the weak points in his case. A generalized interview of such short duration is not an adequate means of testing sincerity.

Despite these shortcomings in present practice, there are probably some occasions when a board could reasonably reject a claim because the personal appearance persuaded it that the claimant should not be believed. Because in the bulk of cases the personal appearance does not provide a firm basis for determining the claimant's veracity, it may nonetheless be unwise to allow a board to deny a claim on this ground alone, rather than force it to unearth available evidence supporting or discrediting the claim it suspects. ${ }^{193}$ Empowering a board to reject a claim on demeanor alone would create considerable danger that demeanor would be cited as the dispositive ground in cases where that ruling was inappropriate. By citing a "shifty demeanor" or an "appearance of unreliability" on the part of the registrant, a board could avoid the burden of checking out a claim, yet render an unreviewable decision. To be sure, there is now a right of personal appearance at the appeal board and the Presidential board level. Their determinations, however, if based on demeanor, will not be reviewable in court as long as the registrant's appearance cannot be preserved in the record or recaptured on appeal. A registrant seeking to challenge a classification in court

gathered, and was given an opportunity to rebut adverse evidence by his own testimony, through witnesses, or by written evidence. See text accompanying notes 147-50 supra.

189 Interview with Selective Service officials at National Headquarters, in Washington, D.C., Aug. 1971. This estimate coincides with that which others have made. See, e.g., Reisner, supra note 55, at 698 (10 minutes); Rabin, supra note 36, at 650 (10-15 minutes), 662 (10-20 minutes).

19037 Fed. Reg. 5122 (1972) (to be codified at 32 C.F.R. $\$ 1624.4(\mathrm{c})$ ).

191 Decision-Making, supra note 134, at 95, reports that things like dress and posture become important in deciding whether to grant claims. See id. 97-98.

192 See text accompanying notes 167-68 supra.

193 Cf. Dyer v. MacDougall, 201 F.2d 265, 269 (2d Cir. 1952) (L. Hand, J.). 
will therefore be effectively barred from judicial review if a finding based solely on demeanor is legally sufficient.

Even a rule that a board cannot reject a claim on the basis of demeanor alone if it has failed to conduct an investigation to produce all available evidence would be insufficient to solve the dilemma. A board that has investigated thoroughly might correctly disbelieve a claim even though no evidence (other than the registrant's appearance) supports disbelief. As will be more fully explored, ${ }^{194}$ the quantum of evidence an investigation produces cannot be dispositive. That there is little evidence to prove the registrant's belief may not provide a basis for disbelieving him; a failure to make external manifestations of one's belief is not inconsistent with strong opposition to participation in war. Nor is it conclusive that an investigation yields evidence supporting the registrant. $\mathrm{He}$ is in full control of whatever evidence does or does not exist on the subject of whether he entertains a particular belief. A registrant whose activities support a conscientious objector claim could have engaged in those activities simply to add to the persuasiveness of his case before the draft board. If third parties attest to the sincerity of his claim, they may themselves be insincere, or the registrant may have persuaded them of the validity of his claim simply to improve his chances of success.

Because the subject of inquiry is so elusive, the rule must either allow the clever registrant to fabricate a foolproof conscientious objector claim (by not allowing the board to rest on demeanor), or permit the draft board to deny conscientious objector claims at will in its unreviewable discretion. If we could trust to an adversary system to see that evidence on both sides of a controversy were produced, and if we trusted the factfinder on the subject of the dispute, we could have greater confidence in a rule permitting denial of a claim on the basis of demeanor alone.

\section{The "Reasons" Requirement}

Prior to the 1971 amendments, the Universal Selective Service and Military Training Act did not require boards to disclose their grounds of decision. Although the Administrative Procedure Act required administrative agencies to give reasons for their decisions, ${ }^{195}$ the Selective Service System has consistently been exempted from the APA. ${ }^{196}$

194 See text accompanying notes 258-63 infra.

195 Section 8(b), 5 U.S.C. $\$ 557$ (c) (1970). See also id. $\$ 4(\mathrm{~b}), 6(\mathrm{~d}), 5$ U.S.C. $\$ \$ 55(\mathrm{e}), 558(\mathrm{c})(1970)$; Model State Administrative Procedure ÁcT \$11. Many states, however, do not require findings in cases tried by judges without juries, and prior to 1930 federal equity courts were not required to make findings. 2 K. Davis, supra note $102, \S 16.03$. Moreover, under Rule 52 of the Federal Rules of Civil Procedure, findings are not necessary in decisions in some cases. Id.

196 See note 56 supra. 
Before 1967, however, boards' failure to explain their decisions was not of great importance in conscientious objector cases, because the Department of Justice, when it made recommendations to the appeal boards for disposition of conscientious objector cases, gave reasons for its recommendations. Courts presumed that the Department's reasons were shared by the appeal board whenever the board followed the result the Department recommended but did not specify reasons for the classification. In Sicurella v. United States, ${ }^{197}$ for example, the Department based its recommendation of rejection on reasoning that the Supreme Court later held legally erroneous. The appeal board denied Sicurella's claim without explanation. The Supreme Court ruled that the "error of law by the Department, to which the Appeal Board might naturally look for guidance on such questions, must vitiate the entire proceedings at least where it is not clear that the Board relied on some legitimate ground." 198 Similarly, when the Department recommended denial of an exemption on alternative grounds, one of which was invalid, and the appeal board followed the recommendation without indicating on which ground it relied, the classification would be reversed because it might have rested on the erroneous ground. ${ }^{199}$ Thus, the courts were left without reasoning to explain the administrative decision only in cases where the appeal board, without explanation, rejected a recommendation that an exemption be granted. ${ }^{200}$ Since the

197348 U.S. 385 (1955).

$198 \mathrm{Id}$. at 392 .

199 United States v. Jakobson, 325 F.2d 409, 416-17 (2d Cir. 1963), aff'd sub nom. United States v. Seeger, 380 U.S. 163 (1965); Clay v. United States, 403 U.S. 698 (1971) (per curiam) ; Ypparila v. United States, 219 F.2d 465 (10th Cir. 1954); Shepherd v. United States, 217 F.2d 492 (9th Cir. 1954) ; United States v. Englander, 271 F. Supp. 182 (S.D.N.Y. 1967) (mem.) ; United States v. Erikson, 149 F. Supp. 576, 579 (S.D.N.Y. 1957). This approach clearly makes sense in a case where the record provides simply a basis on which the board might legitimately have found the registrant disqualified. In such a situation it is possible that the Justice Department's error led to misclassification because the board decided solely on an erroneous ground and did not make the finding on which it could have legitimately denied the exemption sought. In a case where the file shows positively that the registrant was disqualified, however, one might quarrel with the rule requiring reversal because of faulty reasoning. If, for example, the Department recommended against a registrant on all statutory grounds and was in error in its advice that the registrant was not sufficiently religious and was insincere, $c f$. Clay v. United States, supra, but the registrant's file showed clearly that his opposition extended only to particular wars, the doctrine would seem to require that, in the absence of appeal board reasons for denial of the exemption, its I-A classification of the registrant be held erroneous. While it is true that the appeal board might have rejected the registrant's claim on erroneous reasoning, the fact remains that he is not entitled to that classification and that the record reveals that, at least in result, the appeal board's decision was the only correct one. For a court so to decide, however, might be deemed an usurption of the board's function of classifying the registrant in the first instance. Cf. SEC v. Chenery Corp., 318 U.S. 80, 88 (1943).

200 Of course, the reasoning available to courts for review might not in some cases be the reasoning the appeal board actually employed. 
Department's recommendations were usually followed, those cases were uncommon.

After abolition of the Department's investigatory procedure, however, registrants' files in most cases did not show the ground of decision. The anomalous situation resulting from courts' attempts to review decisions whose rationale they could not understand fully explains Congress' recent action.

\section{A. The Need for a Reasons Requirement}

As noted above, ${ }^{201}$ the ultimate issue the Court faced in Dickinson v. United States ${ }^{202}$ was whether a draft board can find against a registrant because it disbelieves him when no evidence supporting its disbelief appears in the record. In fact, it was not clear that the board in that case had disbelieved Dickinson. The file failed to explain the board's rejection of his claim. ${ }^{203}$ Moreover, it affirmatively appeared that there had been an issue whether Dickinson's ministerial activities should be considered his vocation when they were not compensated and he supported himself by working as a radio repairman for five hours a week. The Court held, however, that, under the statute, a man who regularly devotes 150 hours each month, as Dickinson did, to preaching and teaching his faith qualifies as a minister although secular employment is his sole source of support. This conclusion left no evidence in the record supporting any legitimate ground for rejection of Dickinson's claim. There then remained for the Court the question whether the board's determination might have rested on a basis not reflected in the record: that the board did not believe Dickinson's factual assertions were truthful.

To have sustained Dickinson's conviction on the ground that, even though the file contained no evidence of insincerity, the board might have disbelieved the registrant's claim would have made wholly unreviewable every case where the board took the precaution of stating no reasons for denying a claim. If courts were to presume that the board's disallowance of a claim was based upon disbelief of the claimant's evidence, there would always be a "basis in fact." 204 A board would then

201 See text accompanying notes 171-75 supra.

202346 U.S. 389 (1953).

203 Since Dickinson was not a conscientious objector case, there had been no departmental investigation.

204 Even after Dickinson a board's action would have to be sustained whenever the registrant's file indicated a basis in fact for the result reached. If Dickinson had been decided otherwise, however, the decision would have to be sustained also when the file did not show a basis in fact, for it could always be presumed that a board disallowed a claim because it disbelieved the evidence. 
be subject to reversal only when it had committed a prejudicial procedural error or had indicated gratuitously a reason for its decision that was legally indefensible.

While the Dickinson Court refused to adopt that presumption, it did not affirmatively require boards to disclose their reasons. The consequence of the Court's approach is that if a record shows a basis for rejecting a claim on any ground the administrative adjudication will be upheld without regard to the actual reason for the board's denial. In Dickinson the Court surmounted the problem presented by its ignorance of the board's reasoning by finding that each possible ground would have been erroneous. Suppose, however, that there had been some evidence in Dickinson's file contradicting his statement that he regularly spent 150 hours a month as a minister. Whether or not that evidence had in fact influenced the board's decision, it would have provided a basis in the record for the board to disbelieve Dickinson's evidence. That this basis existed would have insulated his case from further review, although in fact the board had discounted the contradictory evidence and believed Dickinson's claim that he worked 150 hours monthly as a minister, and had denied the exemption only because of an error of law-a belief that Dickinson disqualified himself by spending five hours a week as a radio repairman. Only if the board had stated the reasons for its decision would its error in denying Dickinson's claim have come to light.

To cite a more current example, there might be a basis in a registrant's file for believing his conscientious objection relates only to the war in Vietnam, though other evidence-perhaps even the bulk of the record-suggests his objection is to war in general. The draft board has ruled against him without disclosing its reason. Without a reasons requirement, a court must sustain the classification even if the board has in fact decided that the registrant's opposition does extend to participation in all wars. The board may have thought a registrant must belong to a peace church to be exempted. Or, acting arbitrarily and in contravention of Dickinson, it may simply have disbelieved the registrant though there was no basis for disbelief in the record. In neither case would the registrant be able to show that his classification was illegal; there would be a basis in the record for a decision that the draft board did not make-a decision that the registrant is a selective conscientious objector.

Without a reasons requirement, the rules that a board lacks power to resolve issues of fact against a registrant unless there is some evidence unfavorable to him on that issue and that courts will not defer 
to board decisions on questions of law were, then, of no practical effect whenever there was a basis in fact for ruling against the registrant on any ground. A registrant could lose an exemption whenever there was some evidence from which a factfinder could decide against him, whether or not the factfinder did decide against him on the point. $\mathrm{He}$ could be convicted though no factfinder-either court or draft board -had ever thought that the facts on which his conviction was premised were true.

Such a result would be possible in any system where a court did not know the basis for decisions it reviewed and where the scope of review was less than a preponderance of the evidence. In any such case the court might affirm a conviction on a hypothesis supported by the requisite amount of evidence, when neither court nor board had considered that hypothesis truthful. The extreme narrowness of the basis-in-fact standard of review accentuates the problem by making it more likely that a registrant will be convicted on the basis of findings that have never been made. Under that standard, a court must defer to the board's classification even if the evidence unfavorable to the registrant on a crucial issue is very weak. Yet the very weakness of that evidence makes it likely that the board ruled in favor of the registrant on the issue and denied his claim for exemption on some other ground. Moreover, the smaller the amount of evidence needed to satisfy the reviewing standard, the more likely it is to be present in the bulk of the cases. With a basis-in-fact test that was strictly followed and without a requirement that boards give reasons, the only cases where a registrant could expect to correct an erroneous classification in court would be those where all of the evidence on all of the issues unambiguously favored him. ${ }^{205}$

The deference to board decisions that absence of reasons made necessary did not comport with what Estep ${ }^{206}$ had indicated was the

205 The basis-in-fact test, when not coupled with a requirement that boards give reasons, thus became equivalent to a rule that boards' decisions would be sustained whenever there was any conceivable legitimate basis for their ultimate result. The rule amounted to a presumption that the board correctly understood applicable law. It did not result from a conscious policy that all board decisions should stand that could have been reached legitimately whether or not they were so reached, cf. McGowan v. Maryland, 366 U.S. 420, 426 (1961) ("A statutory discrimination will not be set aside if any state of facts reasonably may be conceived to justify it."), but was a rule of necessity-necessitated by ignorance of the board's actual grounds. This was apparent since whenever the reason or reasons for the board's decision appeared, courts did require a basis in the evidence for the reason or reasons given; it was not deemed sufficient that the classification might be proper on other grounds. Indeed, the presumption of correctness was sufficiently weak that a board would be reversed when the record suggested it misunderstood an element of the applicable law but did not show whether the error affected the classification it gave. See text accompanying notes $195-200$ supra.

206 Estep v. United States, 327 U.S. 114 (1946). 
purpose of limited review of Selective Service determinations. The basis-in-fact test was designed to allow boards rather than courts to resolve conflicts in the evidence; it contemplated deference to factual decisions that boards had actually made. If boards act in accordance with the law, those decisions will not be unfavorable to the registrant simply because there is a basis in fact for finding against him. The basis-in-fact standard is a standard of review. Boards, by contrast, have the duty to decide on the basis of all the evidence whether they consider the registrant entitled to the claimed exemption; their function is to rule in accordance with the preponderance of the evidence. ${ }^{207}$ The policy is for courts to defer to findings that boards have actually made in conformance to this standard, not to deny an exemption simply because there is a basis for ruling against a registrant on some ground when no factfinder has actually so ruled.

In sum, the failure of boards to state their reasons often precluded significant judicial review. By the same token, the system was vulnerable to the charge that it contravened Estep's mandate that only classifications "made in conformity with the regulations" are final and that courts will not sustain classifications resulting from lawless board action. ${ }^{208}$

207 When the evidence is in equilibrium, however, the registrant's burden of proof causes him to lose.

208327 U.S. 114, 122 (1946). The absence of reasons might have been attackable on constitutional grounds as well. That would depend upon whether it is constitutionally required that draft boards' decisions be judicially reviewable. Estep did not resolve the question, though it did say that to assume nonreviewability of a classification in a criminal prosecution would be to "infer that Congress departed . . . far from the traditional concepts of a fair trial ..." Id. See also Wechsler, The Courts and the Constitution, 65 Colum. L. REV. 1001, 1004-07 (1965); H.M. HART $\& H$. Wechsler, The Federal Courts and tee Federal System 317-25, 328-40 (1953). Despite Justice Brandeis' comment that '[ $t$ ] he supremacy of law demands that there shall be opportunity to have some court decide whether an erroneous rule of law was applied; and whether the proceeding in which facts were adjudicated was conducted regularly," St. Joseph Stock Yards Co. v. United States, 298 U.S. 38, 84 (1936) (Brandeis, J., concurring), the Supreme Court has not clearly held judicial review, even of constitutional rulings by administrative agencies, to be constitutionally required, let alone review of legal rulings having less than constitutional implications. See generally $4 \mathrm{~K}$. DAvIS, supra note 102, $\$ \$ 28.18-.19$. But cf. Crowell v. Benson, 285 U.S. 22 (1932); Ng Fung Ho v. White, 259 U.S. 276 (1922); Ohio Valley Water Co. v. Ben Avon Borough, 253 U.S. 287 (1920). The present status of those cases is analyzed in $4 \mathrm{~K}$. DAvIS, supra $\$ \$ 29.08-09$. The Court's enthusiasm for avoiding resolution of the constitutional issue by finding that even statutes which apparently preclude review in fact allow it, as the Court did in Estep, may serve as some indication that lack of review is constitutionally suspect. See also, e.g., Harmon v. Brucker, 355 U.S. 579 (1958) (per curiam); Pennsylvania R.R. v. Rychlik, 352 U.S. 480 (1957); Shaughnessy v. Pedreiro, 349 U.S. 48, 51-52 (1955); Heikkila v. Barber, 345 U.S. 229, 232-33 (1953); Elgin, J. \& E. Ry. v. Burley, 325 U.S. 711 (1945), aff'd on rehearing, 327 U.S. 661 (1946) ; Kessler v. Strecker, 307 U.S. 22 , 34 (1939); United States v. Williams, 278 U.S. 255 (1929). And even if judicial review is not generally required by the Constitution, there may be special factors in Selective Service cases that make it constitutionally necessary. Even a court that deems the informality of Selective Service proceedings, the lack of procedural safeguards, and the possible partiality of the factfinder in themselves to be constitutionally acceptable, might come to a different conclusion if Selective Service decisions were 


\section{B. The Analogy to Juries}

Juries commonly fail to disclose their predicates of decision. ${ }^{209}$ It may be argued that whatever reasons support that practice ${ }^{\mathbf{2 1 0}}$ apply equally to draft boards. Draft boards and juries do have certain similarities. Both are factfinding bodies composed of laymen without legal skills, drawn from the community of the persons whom their decisions affect. Differences between draft boards and juries nevertheless justify imposing different rules as to the degree and manner in which they must account for their decisions. The salient differences are in their functions, their constitutional status, and their composition.

\section{Functions}

While juries hear evidence in the presence of a judge, no judicial officer is present at the proceedings that result in draft boards' initial classifications. This difference makes draft boards' factual determinations less subject to judicial supervision than are those of juries. A judge observes all evidence the jury does, contemporaneously with the jury, and can rule upon whether a jury can rationally arrive at a particular verdict. ${ }^{211}$ A draft board, by contrast, judges alone whether there is sufficient evidence to support its decision.

at no stage subjected to judicial scrutiny. Moreover, the consequences of an erroneous Selective Service classification are momentous. Even apart from the criminal liability of a person who fails to comply with a Selective Service order, a person who does comply must spend two years as a soldier, possibly in a combat zone. (Cf. Yakus v. United States, 321 U.S. 414 (1944), allowing limitations on judicial review where criminal prosecution for noncompliance also was possible but where compliance cost only money.) And conscientious objectors whose conscientiously-held beliefs prevent them from entering the military are forced to serve the prison term. That sensitive constitutional issues are involved in the area of conscientious objection, whether or not a conscientious objector exemption is constitutionally required, see notes 289-91 infra, may also make it more important for judicial review to be available than in cases where the issues are freer from constitutional implications. Cf. Ng Fung Ho v. White, 259 U.S. 276 (1922) (requiring judicial determination of citizenship under the fifth amendment though generally the finality clause of the deportation statute was deemed to permit only more limited review).

209 While special verdicts and interrogatories to the jury to be answered along with the general verdict are available devices for obtaining jury findings, they are not normally required in civil cases, F. JAMES, supra note $110, \$ 7.15$, at 295 (1965), and are virtually never employed in criminal cases, see G. CLEMENTson, SpEcras. VERDICTS AND SPECIAL FINDINGS BY JURIES 49 (1905) (only general verdict proper in criminal case) ; United States v. Spock, 416 F.2d 165, 180 (1st Cir. 1969) (terming use of special interrogatories in that criminal prosecution "without precedent").

210 The reason commonly suggested, both by adherents and critics of the current system, is that juries are less controlled, by the judge and by the law, when findings are not required. See, e.g., United States v. Spock, 416 F.2d 165, 180-83 (1st Cir. 1969); G. ClEMENTSON, supra note 209 , at 49 ; F. JAMES, supra note 110 , 7.15 , at 293-99 (1965).

211 See generally F. JAMEs, supra note $110, \S \S 7.13, .16, .20$. A judge also exercises some control over what evidence comes before the jury, $i d$. $\$ 7.12$, and can guard against the jury being influenced by improper considerations. See generally id. 280-336. 
The board's decision, like a jury's, is of course subject to later judicial review. At that stage a judge can decide whether the decision is sustainable. Under prevailing law, it will be if it has any basis in the evidence. A judge cannot, however, review after the fact with the same assurance as one supervising the factfinder contemporaneously, for he cannot observe certain evidence, notably the demeanor of the witnesses, which may have affected the factfinder's decision.

While draft boards, like juries, make factual findings, they also perform the role that trial judges fulfill in judicial proceedings: they decide the applicable law. When one body decides both the law and the facts in a case and that body is excused from stating its grounds of decision, the law as well as the facts are shielded from effective review. ${ }^{212}$ In jury trials deference is paid juries' findings, which they need not explain, but the law of the case remains wholly reviewable. That law is ascertained by examining the court's rulings, the charge, and the instructions to the jury. ${ }^{213}$ Since in draft board proceedings, no person who is not on the board articulates on the record the law to be applied in the particular case, the only way to prevent insulation of that law from review is for board members themselves to reveal what they deem the law to be. By doing so they will make possible more accurate judicial review than is possible with juries; in jury cases the reviewing court knows the law as it was told the factfinder, but it does not know what the factfinder understood the law to be. ${ }^{214}$ But if boards were not required to give reasons, the reviewer would have substantially less assurance what law was applied than it does with juries. ${ }^{215}$

212 When judges try cases without juries and pass on both law and facts, the same problem could arise. The Federal Rules avoid the problem by requiring judges who try cases alone to indicate their bases of decision. FED. R. CIv. P. 52(a). Cf. note 195 supra.

213 In Sparf \& Hansen v. United States, 156 U.S. 51 (1895), it was argued that juries should decide both the law and the facts. The Court, over a strong dissent, rejected that contention. Juries of course retain the pozver to disregard the law as related to them by the judge, but the currently prevailing system is not to inform them of that power but instead to stress their duty to follow the law. See United States v. Moylan, 417 F.2d 1002 (4th Cir. 1969). See also Van Dyke, The Jury as a Political Institution, Center Magazine, Mar. 1970, at 17 (suggesting that jurors should be informed of their powers of nullification).

214 Even when the reviewer knows what the factfinder understood the law to be, it cannot, of course, know whether the factfinder chose to disregard that law.

215 A somewhat analogous system would involve not instructing the jury on the law but informing jurors of the existence and availability of legal sources and telling them to apply their conception of the law to the particular case without disclosing what that conception is. See generally Sparf \& Hansen v. United States, 156 U.S. 51 (1895), discussed in note 213 supra. The analogy is not a perfect one, however, because board members, though nonexpert in comparison to judges, are far more professional than jurors. Draft boards are continuing bodies, and members are expected to know the law they are to apply, though the expectation often fails in 


\section{Constitutional Status}

Another factor supporting greater accountability for draft boards than juries is that the deference paid juries' factual findings is required by the seventh amendment to the United States Constitution. ${ }^{216}$ Under that amendment, a jury's findings cannot be reexamined except as permitted under common law. ${ }^{217}$ By contrast, Congress is not obliged to protect from review the factual findings of draft boards. ${ }^{218}$ Moreover, as will next be discussed, the reasons underlying the constitutional limitation on jury accountability do not apply to draft boards.

\section{Composition}

Nonreviewability of juries' factual findings is deemed a protection to the individuals affected. Juries are thought to represent the people, as opposed to the government. ${ }^{219}$ But if friendliness of the factfinder to the individual as against the system is the rationale for allowing its decisions to be unreviewable, it would be folly to apply the same rule to draft boards. As discussed previously, board members are exceptionally sympathetic to a system of conscription, have an interest stemming from their inquisitorial function in deciding cases on less than

practice. See text accompanying notes $142-43$ supra \& note 143 . Jurors serve for a much more limited term and are not required, or even encouraged, to have any knowledge of the legal system other than that imparted by the judge during the coturse of the trial.

216 U.S. CoNsT. amend. VII.

217

In Suits at common law, where the value in controversy shall exceed twenty dollars, the right of trial by jury shall be preserved, and no fact tried by jury, shall be otherwise reexamined in any Court of the United States, than according to the rules of the common law.

Id.

218 The Selective Service and Training Act, as interpreted in Estep v. United States, 327 U.S. 114, 120 (1946), and the basis-in-fact test there evolved, do, however, oblige courts to defer to draft boards' factual findings. 219 See, e.g., Patton v. United States, 281 U.S. 276, 296-97 (1930). In Duncan v. Louisiana, 391 U.S. 145 (1968), the Court stated:

A right to jury trial is granted to criminal defendants in order to prevent oppression by the Government. Those who wrote our constitutions knew from history and experience that it was necessary to protect against unfounded criminal charges brought to eliminate enemies and against judges too responsive to the voice of higher authority. The framers of the constitutions strove to create an independent judiciary but insisted upon further protection against arbitrary action. Providing an accused with the right to be tried by a jury of his peers gave him an inestimable safeguard against the corrupt or overzealous prosecutor and against the compliant, biased, or eccentric judge.

Id. at 155-56 (footnote omitted). 
adequate facts ${ }^{220}$ and, prior to recent amendment, ${ }^{221}$ also had an interest stemming from the quota system in ruling against the registrant.

It may be argued that juries are trusted not because they favor the people but simply because they temper legal technicalities with common sense, a characteristic that could, depending on the circumstances, favor either party to a dispute. ${ }^{222}$ They are under oath to follow the law, but "jury lawlessness is the great corrective of law in its actual administration." 223 If this is juries' raison d'être, it is essential that they bring to their decisionmaking the sense of the community.

If a group of citizens is representative, it is understandable that the community might be willing to entrust to them the task of decisionmaking on some matters of importance without requiring them to account for their decisions. ${ }^{24}$ To excuse juries, in theory at least selected. at random from the whole community, ${ }^{225}$ from disclosing the findings behind their verdicts saves time and expense. It may even permit juries to render decisions more in accordance with the community's sense of justice than any formulated standards would allow. ${ }^{226}$ The same ra-

220 At one time juries, as draft boards still do, performed the functions of witness and investigator as well as factfinder. As neighbors of the parties involved, jurors were expected to bring to the decisionmaking their personal knowledge of the case, see J. Thayer, a Preitminary Treatise on Evidence at the Common Law $90-91,94-95,104$ (1898), and they had the power to inform themselves from other sources of the facts of a case so that their decisions would be correct. See 6 W. Holosworte, A History of English Law 388 (1924); E. Morgan, Some Problears of Proof Under the Anglo-American System of Litigation 17 (1956); J. THAyEr, supra at 91-94. Jurors have evolved to play quite a different role. Indeed, jurors now commonly must swear to decide a case solely on the evidence presented in the courtroom and they are often disqualified if they know the parties to a controversy or have knowledge of the case from outside sources. Because adverse parties separate from the factfinder have the responsibility of producing evidence on the issues, it is more likely that all relevant evidence will come to light than when one body is both factfinder and investigator and can affect the amount of investigation it must do by its decisions on sufficiency of evidence.

221 See text accompanying notes 139-41 supra.

222 Justice Holmes has said that juries "will introduce into their verdict a certain amount-a very large amount, so far as I have observed-of popular prejudice, and thus keep the administration of the law in accord with the wishes and feelings of the community." O. Holmes, Law in Science and Science in Laze, in CoLLECTED LEgal Papers 237-38 (1920). See Traynor, Fact Skepticism and the Judicial Process, 106 U. PA. L. REv. 635, 638 (1958); Wyzanski, A Trial Judge's Freedom and Responsibility, 65 HaRv. L. REv. 1281, 1286 (1952).

223 Pound, Law in Books and Law in Action, 44 Am. L. Rev. 12, 18 (1910).

224 But see E. Griswold, 1962-1963 Harvard Law School Dean's Report 5-6, quoted in H. KALVEN \& H. ZeISEL, ThE AMERICAN JuRy 5 (1966):

The jury trial at best is the apotheosis of the amateur. Why should anyone

think that 12 persons brought in from the street, selected in various ways, for their lack of general ability, should have any special capacity for deciding controversies between persons?

225 Federal Jury Selection and Service Act of 1968, 28 U.S.C. $\$ \$ 1861-71$ (1970). See Glasser v. United States, 315 U.S. 60, 86 (1942); Brown v. Allen, 344 U.S. 443,474 (1953).

226 See note 222 supra. 
tionale cannot support nondisclosure by draft boards, ${ }^{227}$ when members are appointed, ${ }^{228}$ not randomly selected, and when the middle class, whites, and white-collar workers are grossly overrepresented at the expense of the laboring and lower classes ${ }^{229}$ and minority groups. ${ }^{230}$

\section{Feasibility of the Reasons Requirement}

Until shortly before Congress imposed the reasons requirement, courts generally had not questioned the absence of reasons in Selective

227 But see General Hershey's rationale for entrusting the drafting process to nonprofessionals, text accompanying note 238 infra.

228 The statute provides for appointment by the President on the recommendation of the state governor. Military Selective Service Act $\$ 10(\mathrm{~b})(3), 50$ U.S.C. APP. $\$ 460$ (b) (3) (1970), as amended, 50 U.S.C.A. APP. $\$ 460$ (b) (3) (Supp. 1972). In practice, many board members are selected by their predecessors, a practice that perpetuates the nonrepresentative nature of the boards. Davis and Dolbeare reported in their Wisconsin study that $39 \%$ of the local board members said that they had been recruited by their local board and $43 \%$ said the newest member had been recruited by the local board. J. Davis \& K. Dolbeare, supra note 134, at 66.

229 See J. Davis \& K. Dolbeare, supra note 134, at 58-60 (1966 study-3r/2 times as many proprietors-managers-officials on boards than in employed male population; twice as many professionals and farmers; only $1 / 6$ as many blue collar workers); MARSHALL COMMISSTON REPORT, supra note 135, at 19 (1966 study-70\% in whitecollar occupations; over $20 \%$ of those professional men; $1 / 2$ of remainder are farmers), appendix 73-81; Decision-Making, supra note 134, at 122-26; Note, The Selective Service, 76 YALE L.J. 160, 167 (1966).

230 In 1966 only $1.3 \%$ of board members were black, as compared with $11 \%$ in the national male population. J. Davis \& $K$. DolaEARE, supra note 134 , at 57 ; Decision-Making, supra note 134, at 125; MARSHALI COMMISSION REPORT, stupra note 135 , at 19 . Other minority groups were also underrepresented. Only $0.8 \%$ of board members were Puerto Rican, 0.7\% Spanish American, 0.2\% Oriental, and $0.1 \%$ American Indian. Id. The 1971 amendments may, however, be instrumental in reversing this trend of underrepresentation. In them, Congress requested the President to appoint minority group members to local boards in proportion to their population in a particular jurisdiction. Military Selective Service Act $\$ 10$ (b) (3), 50 U.S.C.A. APP. $\$ 460$ (b) (3) (Supp. 1972), amending 50 U.S.C. APP. $\$ 460$ (b) (3) (1970). More important, Congress lowered the maximum permissible term from 25 to 20 years and lowered the maximum age limit for local board service from 75 to 65 years. $I d$. These age requirements should have a significant impact on the system. The Marshall Commission found in 1966 that $20 \%$ of all local board members were over the age of 70. MARShall CoMimission REPORT, supra at 19. Davis and Dolbeare concluded from the available statistics that the average board in 1966 had only one member under 50 and had at least one over 70 . J. Davis \& K. DOLBEARE, supra at 57. Although the average age of local board members may be lower today, the new length of service and age limits should still have a great impact. National Headquarters estimated that the 1971 amendments would require about $25 \%$ of all local board members to resign. 4 SEL. SERV. L. REP. 44 (1971). The resultant large number of openings as well as the congressional request provide the System with the opportunity to remedy minority underrepresentation.

Prior to the 1967 amendments, the Marshall Commission recommended that board members have a fixed term of 5 years. MARShall CoMMission Report, supra at 5. Congress responded by setting a fixed term, but made the limit 25 years. Military Selective Service Act of $1967 \$ 10$ (b) (3), 50 U.S.C. APP. $\$ 460$ (b) (3) (1970), as amended, 50 U.S.C.A. APP. $\$ 460$ (b) (3) (Supp. 1972). Congress also, at the suggestion of the Marshall Commission, MARSHALl CoMMISSION REPORT, supra at 5 , made women eligible to serve on boards. Military Selective Service Act of 1967 $\S 10$ (b) (3), 50 U.S.C. APP. $\$ 460$ (b) (3) (1970), as amended, 50 U.S.C.A. APP. $\$ 460$ (b) (3) (Supp. 1972). Until 1967, boards had been $100 \%$ male. Marstale COMMISSION REPORT, supra at 19. 
Service cases ${ }^{231}$ despite decisions under the Selective Service Act requiring judicial review and precepts as to the essentials of such review enumerated in other contexts. It is commonplace that review is not apt to be meaningful when the reviewer does not know the basis of the

231 Shortly before the congressional mandate, however, most circuit courts of appeal anticipated Congress by requiring that reasons be stated when conscientious objector claims were denied. See, e.g. United States v. Stetter, 445 F.2d 472 (5th Cir. 1971) ; Scott v. Commanding Öficer, 431 F.2d 1132 (3d Cir. 1970); United States v. Broyles, 423 F.2d 1299 (4th Cir. 1970) (en banc); United States v. Haughton, 413 F.2d 736 (9th Cir. 1969). But see Gruca v. Secretary of the Army, 436 F.2d 239, 245 (D.C. Cir. 1970), cert. denied, 401 U.S. 978 (1971); United States v. Curry, 410 F.2d 1297 (1st Cir. 1969). The timing of the courts' interest in the issue is probably due to abandonment of the Justice Department's investigation of conscientious objector claims. See text accompanying notes 159-60 supra. It is true that claims for exemptions or deferments other than as a conscientious objector were unaffected by the Justice Department procedure, but it was in conscientious objector cases that courts initially required reasons, and most court-imposed reasons requirements appeared to apply only to denials of conscientious objector claims. See, e.g., United States v. Andrews, 446 F.2d 1086 (10th Cir. 1971) ; United States v. Broyles, supra; United States v. Haughton, supra; Dunlap v. Volatile, 4 SEx. SERv. L. Rep. 3114, 3115 (E.D. Pa. Apr. 1, 1971). Contra, United States ex rel. Bent v. Laird, 4 SEL SERv. L. REP. 3739 (3d Cir. 1971) (hardship deferment) ; Townley v. Resor, 323 F. Supp. 567 (N.D. Cal. 1970) (hardship deferment).

Courts did not often state their reasons for limiting the requirement to the conscientious objector exemption. But see United States v. Andrews, supra; Dunlap v. Volatile, supra. One important reason might be that conscientious objector and ministerial claims account for the vast majority of Selective Service cases that appear before the courts. Hansen, supra note 104, at 457 n.19. An absence of reasons in ministerial claims, however, would not have as crucial consequences as in cases concerning conscientious objectors. Since the ministerial exemption turns wholly on objective criteria and the good faith of the registrant is not at issue, see text accompanying notes 176-77 supra, a board ruling on a ministerial exemption has much less leeway in its decisionmaking than does a board passing on a conscientious objector claim. In conscientious objector cases, where the registrant's sincerity is a key issue, the reason for denial of a claim will be much less frequently apparent, since a claim can be denied because of inferences from the facts in the record even when there is no contradictory evidence in the record. See text accompanying notes 176-79 supra.

Other factors explain courts' greater urgency in requiring reasons for conscientious objector claims than for deferments like hardship and occupational ones. There is some discretion in the local board in granting hardship deferments, and at one time there was discretion in granting occupational deferments as well. Because boards had some input into the standards for those classifications, there was less need for a court to have reasons to see whether the board had conformed to a predetermined standard than there is in conscientious objector cases. For in conscientious objector cases draft boards have never had discretion whether or not to grant claims, as distinct from having leeway in the factual determinations they make and exercising often unreviewable judgments in arriving at those factual conclusions. Boards are supposed to follow a statute in conscientious objector cases, granting exemptions only where they find the three statutory criteria are met and denying them only when a criterion is lacking. See text accompanying notes 112-33 supra.

Along with the greater frequency of conscientious objector cases, other relevant factors accentuated in conscientious objector claims may be board hostility to the exemption and the expertise required to understand both the terms of the standard and registrants' supporting statements. See text accompanying notes 134-43 supra. Though these factors may make judicial review particularly necessary in those cases, however, they do not undercut the need for judicial review in other contexts as wella need which the statute recognizes by applying the requirement generally.

It was primarily the inability to provide effective review that led those courts that did so to impose a reasons requirement. Sce, e.g. United States v. O'Bryan, 450 F.2d 365 (6th Cir. 1971); Rosengart v. Laird, 449 F.2d 523 (2d Cir. 1971) (Lumbard, J., dissenting); United States v. Stetter, supra; United States v. Stephens, 445 F.2d 192, 197 (3d Cir. 1971) (Aldisert, J., concurring); Paszel v. Laird, 426 F.2d 1169 (2d Cir. 1970); United States v. Broyles, supra; United States v. Haughton, 
decision to be reviewed; ${ }^{232}$ that when agencies need not disclose the basis of their decisions they can exceed with impunity the powers entrusted them; ${ }^{233}$ and that an agency's action "must be measured by what [the agency] did, not by what it might have done." ${ }^{234}$ The absence of reasons also arguably impinged upon the statutory right of appeal, for courts had observed that losing parties who do not understand the basis for rulings against them are ill-prepared to challenge those rulings they believe are erroneous, let alone to accept them as just. ${ }^{235}$ The most plausible explanation for the long-continued tolera-

413 F.2d 736 (9th Cir. 1969) ; United States v. Reese, 331 F. Supp. 1088 (N.D. Ga. 1971) ; United States v. Dineen, 327 F. Supp. 646 (D. Mass. 1971) ; cf. Clay v. United States, 403 U.S. 698 (1971) ; United States v. Lemmens, 430 F.2d 619 (7th Cir. 1970); Únited States ex rel. Morton v. McBee, 310 F. Supp. 328 (N.D. Ill. 1970). Other commonly given explanations for imposing a reasons requirement were that a claimant's right to a meaningful appeal within the Selective Service System requires that he know the local board's basis for rejecting his claim, e.g., United States v. Stetter, supra; United States v. Stephens, supra (Aldisert, J., concurring); United States v. Dineen, supra; United States v. Lonseth, 300 F. Supp. 857 (D. Ore. 1969) ; United States v. St. Clair, 293 F. Supp. 337 (E.D.N.Y. 1968), and that the requirement avoids arbitrary or lawless behavior by local boards, e.g. 'United States v. Broyles, supra; O'Brien v. Resor, 423 F.2d 594 (4th Cir. 1970); Townley v. Resor, supra.

The scope of the requirement the courts imposed differed from the congressional requirement not only in its limitation to conscientious objectors but in other ways as well. Many courts seemed to require reasons only when the denial was on grounds of sincerity, e.g., United States v. Abbott, 425 F.2d 910, 914 n.5 (8th Cir. 1970); United States v. Broyles, supra; United States v. Haughton, supra; United States v. Washington, 392 F.2d 37, 39 (6th Cir. 1968). Many also appeared to require reasons only when the registrant stated a prima facie case, e.g., United States v. Weaver, 423 F.2d 1126 (9th Cir. 1970). Contra, United States v. Stephens, supra (Aldisert, J., concurring); United States v. Reese, supra. Courts imposing a reasons requirement typically did not make clear the extent of the reasons they were requiring of the board. See text following note 243 \& accompanying notes 244-56 infra.

232 See SEC v. Chenery Corp., 318 U.S. 80, 94 (1943) ("[T]he orderly functioning of the process of review requires that the grounds upon which the administrative agency acted be clearly disclosed and adequately sustained."); United States v. Chicago, M., St. P. \& P.R.R., 294 U.S. 499, 511 (1935) ("We must know what a decision means before the duty becomes ours to say whether it is right or wrong."); City of Yonkers v. United States, 320 U.S. 685, 694-95 (1944) (Frankfurter, J., dissenting).

233 See, e.g., Schaffer Transport. Co. v. United States, 355 U.S. 83, 92 (1957); Cole v. Young, 351 U.S. 536 (1956); Phelps Dodge Corp. v. NLRB, 313 U.S. 177 (1941). Concerning the dangers of leaving administrative agencies uncontrolled, Justice Douglas has reminded us that "[a]bsolute discretion, like corruption, marks the beginning of the end of liberty." New York v. United States, 342 U.S. 882, 884 (1951) (dissenting opinion).

234 SEC v. Chenery Corp., 318 U.S. 80, 93-94 (1943). See also id. at 87; Secretary of Agriculture v. United States, 347 U..S. 645, 650-55 (1954); American Broadcasting Co. v. FCC, 179 F.2d 437 (D.C. Cir. 1949); Saginaw Broadcasting Co. v. FCC, 96 F.2d 554 (D.C. Cir. 1938).

235 This reasoning was evident in In re Gault, 387 U.S. 1 (1967), in which the petitioner contested a juvenile court procedure whereby prior to the hearing the juvenile's parents were told only of a general conclusion of delinquency. They were not informed of the specific facts and charges involved until the hearing itself, and they were given time to prepare to meet those charges only if they denied the facts. The Supreme Court held the procedure constitutionally defective for lack of adequate notice, saying that unless a party was informed of specific charges or factual allegations in controversy and of the specific issues that had to be met to prevail, he could not prepare adequately for the hearing. Id. at 31-34. Similarly, in Goldberg v. Kelly, 397 U.S. 254 (1970), the Court held that "rudimentary due process," id. at 267 , required 
tion of unexplained decisions in Selective Service cases is that the judiciary was persuaded that practicalities required them to indulge in the presumption that boards had correctly interpreted and applied the law. ${ }^{236}$

that prior to termination of public assistance benefits a recipient be given a hearing preceded by "timely and adequate notice detailing the reasons for a proposed termination." Id. at 267-68. "The statement of reasons was riecessary, at least in a case involving factual issues, see $i d$. at $268 \mathrm{n} .15$, so that a recipient could contest the factual basis of the case against him and produce evidence in rebuttal. Id. at 266.

Gault and Goldberg could support a constitutional argument that a registrant in a draft board case must be provided with the grounds for a decision against him. When the registrant does not know the factual assumptions upon which the ruling against him was premised or is not aware in what respect his claim might be legally deficient, he may not address the point that is at issue. It is true that both Gault and Goldberg concerned litigants understanding issues at an initial hearing rather than at a stage of review, and they concerned understanding the charge made rather than a decision made, but these differences should not be determinative. Unless a party is made aware of the contentions advanced against him, he is unable to meet those contentions, whether at an initial hearing or on review. In fact the dilemma is more serious in draft board cases and in Goldberg than it was in Gault. An adversary confrontation was contemplated at the hearing in Gault so the petitioner at that time would learn the charges against him. The absence of any adverse party in Goldberg and in draft board cases, however, makes it possible that a person will never know the case against him and will never therefore be given an opportunity to meet it.

Cases in the Selective Service area dealing with the registrant's right to see adverse evidence in his file also lend some support to an argument that proceedings on appeal cannot be fair unless the board to be reviewed has indicated the grounds for its decision. In United States v. Nugent, 346 U.S. 1 (1953), the registrant contended he was improperly denied access to the report the FBI submitted after it conducted its investigation into the sincerity of his conscientious objector claim. The registrant's argument was that the hearing on the subject of his sincerity, which the statute provided for, would be meaningless if he was unable to know the contents of the report so that he could refute them. The registrant had been provided, however, with a resume of the report fairly summarizing the adverse evidence but omitting the names of the persons interviewed. The Court held it unnecessary under the circumstances to disclose the report, over a dissent by Justice Frankfurter claiming that the main purpose of a hearing-to give the registrant an opportunity to rebut adverse evidence-was frustrated when the registrant was denied knowledge of the source of the information. In the later case of Simmons v. United States, 348 U.S. 397 (1955), it became clear that the existence of a "fair resumé" was essential to the Nugent holding. The Court held Simmons was deprived of the hearing the statute guaranteed him when the FBI failed to furnish him with a resumé of the information its investigation produced. The Court said the fair resume that was required "is one which will permit the registrant to defend against the adverse evidence-to explain it, rebut it, or otherwise detract from its damaging force. . . The Congress, in providing for a hearing, did not intend for it to be conducted on the level of a game of blindman's buff." Id, at 405. Similarly in Gonzales v. United States, 348 U.S. 407 (1955), decided the same day as Simmons, the Court held that a registrant had a right to a copy of the Department of Justice's recommendation to the appeal board: "Just as the right to a hearing means the right to a meaningful hearing ...., so the right to file a statement before the Appeal Board includes the right to file a meaningful statement, one based on all the facts in the file and made with awareness of the recommendations and arguments to be countered." Id. at 415.

These decisions do not, of course, control the issue of boards giving reasons, for in Simmons and Gonzales the decisionmaking boards could consider information that the registrant was unable to confront. If boards omit reasons, by contrast, reviewing tribunals and the registrant are equally ignorant of the basis for the decision that is to be reviewed. The registrant's major difficulty therefore is not in confronting the adverse evidence as much as it is in securing his right to have the local board's decision reviewed. Since the reviewing tribunal is unaware of the basis for the initial decision, its action appears less like review than like de novo decision with a very large presumption against the registrant (the board's result being sustained if there is any basis in fact that could support it).

236 See note 205 supra. 
Two characteristics of draft boards are pertinent in this connection: (1) draft boards can lay no claim to expertness in the administration of the law; and (2) the boards operate under heavy time pressure.

The point may be restated in the form of a question: Will the reasons requirement, now formally adopted by Congress, debilitate mobilization because board members, unschooled in law, will be unable to give reasons for their decisions adequate to pass judicial muster? To argue that boards of laymen cannot give sustainable reasons because they do not understand the legislative scheme under which they are operating and the rules they apply would prove too much; it would show that the existing system of administering the Selective Service laws is intolerable. If, on the other hand, the fear is that boards will be reversed though their bases of decision are essentially correct, simply because boards do not use legal niceties in explaining their decisions, and if that fear is well founded, it militates against a reasons requirement.

The solution, however, is not to abandon the requirement of a reasoned decision but to refrain from requiring of boards of laymen a form of decision they are unable to provide. Courts should simply require boards to set out directly and in an informal, unsophisticated manner their actual reasons for disposing of cases as they do. ${ }^{237}$ If the statute's complications preclude boards from giving actual reasons that comport with the law, the solution is either to remove the complications from the statute so that civilian boards can administer it, or to utilize boards with the skill to follow it. It satisfies no policy to operate under a law that cannot be correctly interpreted and applied by the agency to which it is entrusted.

237 Under the Agricultural Adjustment Act of 1938, 7 U.S.C. $\S 1281$ et seq. (1970), boards of laymen acting as "part time administrators" under a complex statute the terms of which are rather vaguely defined, Fulford v. Forman, 245 F.2d $145,151-53$ ( 5 th Cir. 1957), have been required to render reasoned decisions. Under the Act a "County Committee," comprised of three local farmers elected by the farmers in the cotunty, sets the quota permitted each farmer for tobacco, cotton, rice, and peanuts. The quota is reviewable by a "Review Committee," an appointed body of three other local farmers. In Austin v. Jackson, 353 F.2d 910 (4th Cir. 1965), the Fourth Circuit, over the Government's protest that the Review Committee was not qualified to write explanations of the great number of decisions it was called on to make, imposed on Review Committees the "duty to render a reasoned opinion," saying the requirement was "especially important where the administrative tribunal is lacking in legal expertise." Id. at 911. See also Stallard v. Review Comm., 275 F. Supp. 931 (W.D. Va. 1967). Despite the Secretary of Agriculture's dire predictions as to the effect the decision would have on the administration of the program, Letter from Secretary Freeman to Assistant Attorney General, Civil Division, Department of Justice, Jan. 1966, on file in the Department of Justice, five and a half years after the decision the Department's Deputy General Counsel reported that there had been only "five or so" instances in which the district court had remanded to the Review Committee for an elaboration of its reasons, in addition to "several" where the Department of Agriculture had itself asked the court to remand for elaboration, and that the system was "working well." Telephone interview with Claude Coffman, Deputy General Counsel of the Department of Agriculture, June 1971. 
Adding to board members' previous responsibilities the task of explaining their decisions could arguably interfere with the ability of the Selective Service System to mobilize manpower speedily. The articulation of reasons is obviously an added demand, even if a simple disclosure of the board's rationale is deemed sufficient. Thus, it might prove necessary to increase the number of board members or the amount of time that current members spend at their job. If this proved impracticable, a basic change in the structure of the current system-a professionalization of the draft boards-might prove necessary. General Hershey has warned against that course:

The people of the country will support a compulsory system only to the extent that they have confidence in its fairness and they will have confidence in a system only to the extent which they themselves operate it. The Selective Service System is, therefore, founded upon the grassroots principle, in which boards made up of citizens in each community determine when registrants should be made available for military service. ${ }^{238}$

While the idea of having a man's "friends and neighbors" ${ }^{239}$ rather than a distant bureaucrat determine whether he must serve may, in the abstract, seem attractive, it is questionable whether on balance that system increases public confidence in the fairness of the draft. ${ }^{240}$ The unrepresentative nature of draft boards detracts from the appeal of the "friends and neighbors" concept; so, also, would the high price paid for their volunteer character if the result is short shrift to requirements of basic fairness. ${ }^{241}$ Nevertheless, the Selective Service has rested upon

238 L. Hershey, Memorandun on Present Operations of the Systens and Local Draft Boards, S. Doc. No. 82, 89th Cong., 2d Sess. 4 (1966). 239

The civilians were neighbors. They were, as it were, indigenous to the soil. The men were well-known in the neighborhood. They were often personal friends or family friends of the men who were to be sent to war. They had the intimate knowledge of family histories and of individual histories.

E. Fitzpatrick, Conscription and America 46-47 (1940), quoted in DecisionMaking, supra note 134, at 104. The author was a State Director of the Selective Service during World War I.

240 See J. Davis \& K. Dolbeare, supra note 134 , at $7,172-90$.

241 As against the disadvantages, an asserted advantage of having local men classify registrants is that they know the men they draft. See Hershey, Review of the Organization and Administration of the Selective Service System 9694. This is no longer true, however, if it ever was so. J. DAvis \& K. DolBEARE, supra note 134, at 9499, 197; MARSEALI COMIMISSION REPORT, supra note 135, at 20. If "friends and neighbors" ever adequately described the local boards, the urbanization of America's population and high registrant mobility have, for the majority of the population, reduced General Hershey's characterization to little more than a bitter joke. MARShali Comaission Report, supra at 20 ; J. Davis \& K. Dolbeare, Who Gets Drafted 31 (1967); G. WAMrsley, supra note 134, at 112-16. Wamsley reports the following comment by a local board clerk in an urban area who was asked whether board members knew many of the registrants:

Oh no. They're familiar with the district, but they don't know the kids that come in. You know the induction notices used to read: "Your friends and 
volunteer, local boards since 1917; the System has made great claims for the "friends and neighbors" concept;"242 and Congress has consistently rejected proposals to change the structure of local boards. ${ }^{243}$

\section{Interpretation of the Requirement}

The degree to which the reasons requirement can be executed by boards as they are presently constituted depends in large part on how one interprets the requirement that a board "furnish to [the] registrant a brief written statement of the reasons for its decisions." It might be deemed to direct boards simply to state the statutory ground of decision. Boards could comply with that directive merely by informing a registrant that his objection was found not to be grounded upon "religious training and belief"; that his opposition was found not to extend to "participation in war in any form"; that he was deemed insincere in his expressed belief; or any combination of these factors. The statute may, however, require something more. It may require reference to the evidence on which the board relied in reaching its finding that the statutory criteria were unsatisfied. Or it may even compel the board

neighbors have selected you"-and it got so it made people so mad that they dropped it. One fellow came in here boiling mad and said, "Who are these friends and neighbors? I want to see them right now."

Id. 115 .

242

It would be essential to avoid in any way interfering with the present decentralized approach of the system which has proved so successful in contrast with the centralized ones of both the Federal and Confederate governments during the Civil War. The decentralized, or local board, or grassroots operation of Selective Service began with the First World War and demonstrated that the Nation would much more willingly support compulsory military service operated by their neighbors at home, than they would a program operated by a remote, impersonal organization.

Hearings on the Administration \& Operation of the Selective Service System Before the House Armed Services Comm., 89th Cong., 2d Sess. 9993 (1966) (statement of General Hershey).

The military establishment, the machinery of Federal Government, even the machinery of state and local governments, appeared not close enough or intimate enough to deal with so vital and elemental an effort. The local board, a group of neighbors deciding who from the neighborhood should be selected for armed service, became the foundation on which the System was built, and gave to it its universality and commonness.

Selective Service System, Organization and Administration of the System 187 (Special Monograph No. 3, 1951).

[W] are only seeking . . . about $1,000,000$ out of $11,500,000$, so there has to be an equity decision.

Somebody has got to decide which one of the 11 is to be taken, and I do want to impress upon all the fact . . . that the choice is being made by the neighbors of the man ...."

Hearings on S. 4164 Before the Sente Comm. on Military Affairs, 76th Cong., 3d Sess. 384 (1940) (statement of General (then Major) Hershey).

243 E.g.g compare the MARSHALL COMMISSION REPORT, siepra note 135, proposals at 35-36, with the relatively minor changes in local board structure adopted in the Military Selective Service Act of 1967, $\$ 1$ 1-23, 50 U.S.C. ApP. $\$ \$ 451-73$ (1970), as amended, 50 U.S.C.A. A.P. $\$ \$ 41-73$ (Supp. 1972). 
to explain why it found that evidence, as opposed to other contradictory evidence, persuasive. Registrants will benefit from whichever of these interpretations is adopted, for each possibility will augment the reviewability of board classifications. The degree to which the registrant benefits will vary, however, as will the weight of the burden the requirement places on the board.

\section{Simple Indication of Statutory Ground}

Board members should hardly be overburdened by a requirement that they simply identify the statutory basis of their decision. Presumably board members have reasons, even in the absence of a reasons requirement, for denying a claim. The only new responsibility would be to indicate succinctly what that reason is. To do so would take only moments. In each case, every board member could be furnished a checklist with three boxes, one for each statutory ground of decision. The member could check the one or more grounds that showed his reason for voting to deny in the particular case. The availability of these checklists to the registrant and to the reviewing court would avoid the anomaly of a court affirming the board's decision on a ground upon which the board did not rely. It would also apprise the registrant of the ground to which he should direct his argument on appeal.

This, to be sure, would not invariably narrow the issues. For example, board members might have different reasons for denying a registrant's claim. Of three board members passing on a conscientious objector claim, one might find the registrant selective, one might find him nonreligious, and a third might find him insincere. As a result the board would deny his claim. The registrant arguing that there was no basis in fact for his classification would be in a position similar to that of the registrant before a reasons requirement was imposed who had to show that there was no basis on any statutory ground for denying his claim.

One might argue that the proper approach is to have the board give its reasons for denying a registrant's claim rather than have each member do so, and that if a majority of the members cannot agree upon grounds for denying the claim, the registrant prevails. In the example given, since two out of three board members found for the registrant on each statutory ground, he should prevail in his claim, just as he would if a single person were factfinder and were two-thirds convinced of the registrant's case on each statutory issue. It is settled, however, that when courts comprised of more than one judge decide a case-civil or criminal-it is sufficient for a verdict that a majority of the panel reaches the same ultimate conclusion although the reason- 
ing of the members of the majority differs. Similarly a jury must agree on the ultimate verdict-guilty or not guilty in a criminal case; judgment for the plaintiff or judgment for the defendant in a civil case-but each jury member may reach that decision on differing grounds. ${ }^{244}$ In the light of these rules it is difficult to argue that a registrant whose draft board finds against him on the ultimate issue is entitled to an exemption because there is no majority for any particular ground of decision against him.

Even though board members might use differing reasoning to find against a registrant, registrants would benefit from boards' expression of their statutory grounds of decision. In most cases board members would agree as to one or more possible grounds of decision, and thereby eliminate those grounds from the case. Even where all possible grounds remained, if it were a close question whether there was a basis in fact on any particular ground to support the board's denial of an exemption, awareness that a majority of board members favored the registrant on that ground might influence the court's decision. Most important, when one of three board members found against the registrant on each statutory ground, a basis in fact on one ground (on which two board members found for the registrant) would not be enough to sustain the classification. To sustain the decision made by a majority of the board there would have to be a basis in fact to support a decision against the registrant on two statutory grounds.

There is one situation, however, where despite boards' indication of statutory grounds a registrant may still have to show that no evidence supports any statutory basis of decision: if a majority of board members finds that the registrant has failed to satisfy any statutory requirement for exemption-that on the basis of his statement he does not satisfy the religious training and belief requirement and is a selective objector, and that he is insincere as well. Similarly, the registrant will benefit less from the statement of grounds when a majority gives two grounds than when it states only one. Unscrupulous board members might increase the likelihood of having their decisions upheld by automatically indicating all statutory grounds when they found against a conscientious objector claim. Yet a rule that board members could indicate only one ground of decision would be artificial and unrealistic.

244 A problem similar to that of the draft board whose members differ in their reasoning could arise with a jury in a special verdict situation. A jury might, for example, find for the defendant on every finding submitted to it but its verdict on the ultimate conclusion might be against him because jurors found against him on differing grounds. If the apparent inconsistency between the findings and the general verdict is so explainable, the general verdict should stand. Otherwise the submission of the special verdict would change the outcome of such a case. The general rule is that both verdicts should stand if possibly consistent. See, e.g., Kirkendoll v. Neustrom, 379 F.2d 694 (10th Cir. 1967). 
Certainly in some cases board members can in perfectly good faith determine that an applicant fails to satisfy the statutory criteria in more than one respect.

No remedy for this situation is apparent. It was noted earlier that when the Department of Justice made recommendations to appeal boards in conscientious objector cases and recommended against a registrant on more than one ground, a classification was reversed if the Department had erred in one of its assessments. ${ }^{245}$ The principle should not carry over to a statement of reasons by draft boards. The rationale for the rule as to the Department of Justice-a rule which applied only when the appeal board did not indicate the reasons for its decision-was that it was impossible to know on which ground or grounds the appeal board had rested. It might have rested solely on the ground on which the Department gave erroneous advice. When a draft board, by contrast, finds against a registrant on three statutory grounds and is in error as to only two of them, it has still found against the registrant on a legitimate and sufficient basis.

\section{Identification of Evidence Relied Upon}

While registrants are aided by a rule requiring that they be informed of the statutory ground of board decisions, they would benefit more if board members were required as well to indicate the evidence in the registrant's file on which they rely in denying his exemption. A registrant appealing the classification his local board has given him would be much better able to meet the issue by supplementing his file before the appeal board if he were aware of the evidentiary basis of the board's decision. Without disclosure of the evidence relied on, he might be unaware that certain evidence was significant to the disposition of his claim. Aware of its importance, he could present to the appeal board any additional information showing that the evidence the local board relied on was untrue or that the inference drawn from the evidence was unwarranted. Additionally, he might show that the evidence cited did not constitute a proper basis in fact.

If the appeal board rejects a registrant's claim, he cannot contest his classification in court by supplementing his Selective Service file. Nonetheless, the registrant would benefit from the focusing of the issue that knowledge of the evidentiary basis for the board's decision would bring. The reviewing court, in order to uphold the decision of the appeal board, would have to find that the evidence the board relied on provides a basis in fact for the denial. It would not suffice that there was other evidence in the record that could constitute a basis in fact 
if board members had rejected the relevance, reliability, or persuasiveness of that evidence. Courts would thus be applying their narrow scope of review to the decision actually made. If board members differed in the evidence they relied on in rejecting a registrant's claim, the grounds of decision of a majority of the voting members would have to constitute a legal basis for the rejection.

A requirement that boards give the evidentiary basis for their decisions thus would protect against upholding legally erroneous decisions on the hypothesis that the board relied upon evidence it actually discredited. It would also bring to light legal errors by the board. One mistake it might either reveal or correct is board reliance on evidence outside the file. For example, the regulations forbid a board to reject a claim because of statements at the personal appearance unless it transcribes the statements and places them in the file. Without a requirement that the board cite the evidence relied upon, a court would have no means of learning that the actual basis of decision was evidence that the board had failed to incorporate in the record. The board might be sustained on the basis of other evidence which had not in fact persuaded it to rule against the registrant. ${ }^{246}$

Boards may also rely on evidence that is factually insufficient to support their result. When all the evidence supports the claim that a registrant became a conscientious objector at age eighteen, the fact that he worked in a munitions plant at age sixteen is not a basis in fact for a decision that his conscientious objector claim is insincere. A more common situation is for a board to rely on a factor that courts have said is legally insufficient to support denial of a claim. For example, a board that relies solely on lateness in filing to show insincerity would have its classification overturned. Interesting legal questions would arise if a board gave the fact that a registrant was not a churchgoer as one of several grounds supporting its finding that his opposition was not the product of "religious training and belief"; or if a board pointed out that a registrant had said he would kill in self-defense as one reason for its ruling that the registrant was a selective objector. Courts have ruled that a person need not be a churchgoer, or even a member of an organized church, to qualify for exemption. Nor need a person renounce the use of force in self-defense. It is unclear, however, whether these facts are regarded as immaterial or whether they are merely

246 If, after the reasons requirement, boards are required to reveal the evidence for their rulings, a board that simply cited "inconsistent statements at the personal appearance" as the basis for its denial on grounds of insincerity would have its classification overturned because the supporting evidence did not appear in the file. $A$ board could avoid this result by complying with the rule that it include in the file all evidence upon which it relies; it would spell out what the registrant's inconsistent statements were. 
deemed legally insufficient when unaccompanied by other evidence adverse to the registrant. ${ }^{247}$

To require boards to specify the evidence on which they have relied would doubtless impose a greater burden than a simple requirement that they state the statutory ground. The burden should not, however, be overwhelming. Presumably board members are aware of the evidence that persuades them even in the absence of such a requirement. If they are not, the requirement may serve an added beneficial purpose of increasing the care with which they make their decisions. Simple expedients could be adopted for identifying the evidence that influenced the board. A board could, for example, mark with red pencil those portions of the file which were the evidentiary basis of decision. (If board members differed in their evidentiary basis, each could use a different color pencil or each could submit a marked copy of the file. A board could adapt to the situation where there was more than one statutory ground, each with a separate evidentiary basis, in a similar manner.) Even in the most complex situation, adding to the decisional process the burden of marking the evidentiary material significant to it should not add more than a few minutes.

\section{Statement of Rationale}

Only if boards must give more than their statutory and evidentiary bases of decision and explain as well their rationale-why they consider the evidence on which they rely to be persuasive-would they be obliged to write opinions. Arguably the phraseology of the new statutory requirement-the board "shall, upon request, furnish to [the] registrant a brief written statement of the reasons for its decisions"suggests that this is in fact the requirement. ${ }^{248}$ If so, as discussed earlier, ${ }^{249}$ the reviewing court should be content with an informal and unrefined statement of the board's reasoning. It should demand only

247 That these facts are legally insufficient to provide a basis in fact for denial of conscientious objector status is clear, see text accompanying notes 6-7 supra, and since "any evidence" can serve as a basis in fact, this would suggest that they are no evidence at all. Courts have not said, however, that these facts are immaterial but simply that they are "consistent with conscientious objector status," United States v. Haughton, 413 F.2d 736, 742 (9th Cir. 1969) (willingness to use force in certain circumstances not a proper basis for denial), or that they do "not necessarily negative a conscientious objection" Shepherd v. United States, 217 F.2d 942, 945 (9th Cir. 1954) (use of force). See United States v. Harris, 1 SEL. SERV. L. REP. 3360 (D. Ore. 1968) (defendant's refusal to be baptized as Jehovah's Witness and thereby become true member of the faith not basis in fact for denial of I-O claim).

248 The regulations require the board to "record its reasons" for rejecting a claim in his file and to inform the registrant of those reasons when he is notified of his classification. 32 C.F.R. $\$ 1623.4$ (c) (1972).

249 Text accompanying note 237 supra. 
enough to satisfy itself that the board has not misunderstood the critical considerations. Boards might tend to be more careful in the processes of decisionmaking if they had to spell out, however succinctly and informally, their reasoning processes. ${ }^{250}$ Moreover the requirement, so construed, would expose some errors that would not be evident from a mere citation of the statutory ground and of the evidence relied upon.

The need for statements of boards' reasoning is reduced, however, in decisions that are not to be reviewed further within the Selective Service System because of the rule that courts must uphold a board's decision whenever it is supported by a basis in fact. ${ }^{251}$ In some cases, boards' explanations might disclose a legal error, or an explanation might be necessary before the court could understand why the cited evidence lends any support to the decision. Generally, however, since courts are not concerned with the persuasiveness of the evidence cited in the light of any conflicting evidence, and since the registrant to prevail must show that no evidence in the file supports his classification, an identification of the statutory ground of decision and the evidence on which the board relied will allow the court fully to perform its functions. The same would not be true before an appeal board or the Presidential board, because their task is to determine the registrant's classification on the basis of all available evidence. ${ }^{252}$ Boards' explanations of their adjudications are more likely to augment the accuracy of the decisionmaking process at this stage by enabling the registrant and the appellate board to explore the validity of the earlier determination. In cases where it is clear that a registrant can obtain further review within the Selective Service System, therefore, a board ruling against him might be required to state its rationale. Unless the basis-in-fact stand-

250 Judge Frank once said that the most important purpose of the findings requirement in trial courts was "that of evoking care on the part of the trial judge in ascertaining the facts. ... Often a strong impression that, on the basis of the evidence, the facts are thus-and-so gives way when it comes to expressing that impression on paper." United States v. Forness, 125 F.2d 928, 942 (2d Cir.), cert. denied, 316 U.S. 694 (1942). Contra, Sunderland, Findings of Fact and Conchisions of Law in Cases Where Juries Are Waived, 4 U. CHI. L. Rev. 218, 228-29 (1937).

251 The standard of review in the Agricultural Adjustment Act cases requiring Review Committees to give their reasoning, by contrast, was a substantial evidence standard. See, e.g., Jones v. Hughes, 400 F.2d 585 (8th Cir. 1968). See note 237 supra.

252 If the appeal boards' classifications were truly de novo and earlier determinations were not at all influential, reasons for the earlier determinations would not be necessary to their functions. Despite cases saying appeal boards' determinations are de novo, however, it is clear that earlier rulings are of at least some influence. If they were not, demeanor could not have been of any influence prior to the recent amendments, unless it was fully described in the record, for appeal boards did not grant personal appearances. Yet pre-1971 cases seemed to indicate that simply an adverse notation as to demeanor in the record would be a sufficient basis for a court to sustain an appeal board's classification. Witmer v. United States, 348 U.S. 375, 382 (1955) (analyzing facts in record only after finding no indication of "shifty or evasive" demeanor); United States v. Corliss, 280 F.2d 808, 814-16 (2d Cir. 1960). 
ard is abandoned, a statement of the grounds and evidence relied upon might suffice in cases where only judicial review seems likely. ${ }^{253}$

\section{E. Evaluation of the Reasons Requirement}

Whichever interpretation of the reasons requirement prevails, it will serve in some measure to increase the effectiveness of judicial review. It should also stimulate boards to exercise greater care in making their determinations. If an interpretation requiring specification of either the boards' evidentiary basis or their full reasoning is adopted, the requirement could also go far towards controlling any tendency boards might have to pick a ground of decision arbitrarily, that is, to choose it not because it reflects their actual reasoning processes but because it will withstand judicial scrutiny.

Either of these two interpretations would limit the extent to which a board could undermine the purposes of a reasons requirement by citing all possible reasons. As previously noted, a board operating under a requirement that it simply state its statutory grounds could list all statutory bases for finding against a claimant. Under a rule that a board must indicate the evidence on which it relies, however, it would be more difficult for a board to impede effective review by this tactic. ${ }^{254}$ Likewise, a requirement that the board state its reasoning would inhibit any tendency in this direction. . $^{255}$

If one of the more demanding interpretations of the reasons requirement is adopted, there will also be less likelihood of improper reliance on demeanor evidence. The vexing question whether a board should be empowered to reject a registrant's story on the basis of de-

253 The rules as to which cases go to the Presidential board make it impossible for an appeal board to ascertain with certainty all cases where further review within the system will be had. See text accompanying notes 67-68 supra. If the suggested approach were adopted, local boards should give full reasoning in all cases, and the Presidential board would never be required to give full reasoning. Appeal boards would have to do so, at least in cases where the appeal board was not unanimous. If appeal boards gave full reasoning only in such cases, there would be some instances -those where the State or National Directors appealed-where the appeal board had not given full reasoning but where there would be further review within the Selective Service System.

$254 \mathrm{~A}$ board could do so only by indicating every piece of evidence that could possibly support its decision as an independent basis of decision. The tactic would backfire, however, if the board neglected to state that the grounds were independent of each other. Moreover, if a board indicated a great deal of evidence in the file, including evidence that could not possibly support its decision, the bad faith of the board would be apparent, and a court should rule that the board had not complied with the requirement.

255 If a board required to spell out its reasoning could state all possible reasons as independent bases of decision, the registrant could be deprived of all benefits the reasons requirement provides. As a practical matter, however, the board would usually be unable to eliminate the benefits of the requirement in this way. It might decrease the helpfulness of the requirement by maximizing the number of independent reasons it gives, but as long as it does not cover all possibilities, it will not eliminate the utility of the requirement. 
meanor alone was adverted to earlier. If demeanor is deemed sufficient, boards at the least should have to describe fully what it was in the registrant's demeanor that influenced the board. A bare declaration that the registrant seemed "shifty" or gave an "appearance of unreliability" would not insulate the administrative decision from reversal. Requiring in this fashion a fuller description of demeanor should cut down on any tendency boards may have to make adverse demeanor findings automatically as the easiest way to deny a claim.

The requirement might also contribute to the reviewability of demeanor evidence. The usual rule of review-that a board's decision will be sustained if any evidence supports it-still admits of an inquiry whether in the particular case demeanor provides "any evidence" supporting rejection of the registrant's claim. The registrant's demeanor is obviously not always sufficient to serve as an independent basis for decision against the registrant, even if there is a rule that demeanor can serve as the sole basis in fact. A requirement that the board must describe fully the registrant's demeanor (or, additionally, give its reasons for considering the demeanor influential) would make it possible for a court to make a more informed judgment whether in a particular case the demeanor evidence does constitute a basis in fact for disbelieving the registrant. ${ }^{256}$

\section{Remaining Problems}

Despite the improvement the reasons requirement represents, the administration of the Selective Service System remains seriously flawed. The virtue of that requirement is that it will bring more into the open what boards are doing and thus make it more probable in any given case that the ultimate decision is in accord with the prevailing rules. To the extent that past difficulties in accurately discerning who is a conscientious objector lay in the rules themselves, however, the

256 The reasons requirement could cut down on board misuse of demeanor in another way as well : the requirement will clarify just how strong the demeanor evidence against a registrant is. A court might require a particularly strong showing of demeanor evidence to support rejection of a registrant's claim in cases where the file shows a very strong case for the registrant on the paper record, or where it shows obvious sources of relevant information that the board has failed to pursue. Under the basis-in-fact test, however, it would seem improper for a court in this way to balance the strength of the registrant's case against the strength of the demeanor evidence. The sole inquiry that test allows the court to make is whether demeanor serves as any basis in fact for the board's decision; theoretically that determination should be made without regard to other evidence in the registrant's file. Moreover, it is conceivable that the board's description of demeanor will show it to be a basis for disbelieving only some of a registrant's evidence but not enough to defeat a prima facie case. The registrant then would have satisfied his burden of proof unless there were other unfavorable evidence in the record, or unless the registrant's insincerity as to some evidence can be affirmative evidence against him, allowing disbelief of other of his evidence. Cf. Dyer v. MacDougall, 201 F.2d 265 (2d Cir. 1952). 
reasons requirement has little ameliorative effect. Other reforms could improve the situation. Thus, lengthier personal appearances with full procedural rights could be guaranteed registrants; the power of boards to deny a classification because of demeanor could be limited to situations where no more concrete evidence is available; exaggerated deference to boards' factual findings could be avoided by frank adoption of a broader standard of review than the basis-in-fact test; means might be sought to make the factfinding body more representative of the population. One of the most significant ways to reform the decisionmaking system would be to provide for meaningful investigation of conscientious objector claims. This could be done by reinstituting a Department of Justice investigation of the kind that existed until mid-1967.57 Alternatively, draft boards themselves might be required thoroughly to investigate before any deference could be given to their factual determinations. This approach might well require professionalizing draft boards so that members would have adequate time to spend at the job.

Even if the full range of reforms were provided, however, problems of unreliable conscientious objector determinations would remain. There would be cases where investigation would not help because there simply is nothing to confirm or refute a registrant's own statement in support of his claim. Moreover, present criteria for conscientious objector status-whether a registrant's belief is sincerely held and "occupies a place in the life of its possessor parallel to that filled by the orthodox belief in God of one who clearly qualifies for the exemption" ${ }^{258}$-are too elusive to admit of reliable application. ${ }^{259}$ Impartial and full consideration of claims based on all available evidence will not, therefore, provide assurance that the conscientious objector exemption is being correctly and uniformly applied.

In all conscientious objector cases there are inherent difficulties. The determination depends on the registrant's state of mind in relation to a subject which is peculiarly personal and which involves a complex of emotional, psychological, and ideological factors. Moreover, the incentive to dissemble or falsify is extreme. In instances where it is available, the factfinder can take some comfort in circumstantial evidence casting light on the honesty of the registrant's self-serving state-

257 The inability to keep up with the caseload that apparently led to abolition of the procedure could be avoided by appropriating funds to hire sufficient staff to handle the caseload. See text accompanying notes 159-60 sitpra.

258 United States v. Seeger, 380 U.S. 163, 166 (1965).

259 In United States v. Nugent, 346 U.S. 1, 10 (1953), though decided at a time when the exemption was interpreted as limited to the traditionally religious and when the Department of Justice investigatory procedure was in effect, the Court nevertheless recognized that "[i]t is always difficult to devise procedures which will be adequate to do justice in cases where the sincerity of another's religious convictions is the ultimate factual issue." 
ment of his beliefs. The man who can show membership in a traditionally pacifist sect, for example, has convincing circumstantial evidence of his opposition to participation in war. Even for him, however, the evidence is not conclusive; he might have joined simply to strengthen his conscientious objector claim. If he joined the sect at an early age and if his participation in religious activities has been regular and full, the credibility of his claim increases. ${ }^{260}$ Even so, it is possible that he is a farsighted dissembler.

A registrant who is religious in a traditional sense but who is not a member of a peace church has a more difficult task. Such a registrant must rely on circumstantial evidence to convince the board not only that the teachings of his church are central to his life, but also that he has in good faith reached the conclusion that those teachings forbid his engagement in war.

Most troublesome for the factinder, however, are the cases in which the applicant for conscientious objector status has no church affiliation. The claims of some persons without traditional religious affiliations may be clearly provable or disprovable. Generally, however, they are the least susceptible of accurate determination. An unaffiliated registrant may be totally sincere, yet have no objective evidence to corroborate his assertion that he believes it would be wrong for him to participate in war. $^{261}$

The registrant who can do no more than describe his inward beliefs is in a dilemma: his claim may not be believed simply because it is easily fabricated and impossible to prove or disprove. ${ }^{262}$ The draft board shares the problem: if it were to reject all such claims on the ground that the registrant had never performed an overt act that showed, even circumstantially, that his claim was legitimate, it could well reject the claim of a registrant who was, under Seeger and Welsh, entitled to a conscientious objector exemption. If, on the other hand,

260 See note 261 infra.

261 In fact, studies show that draft boards are most likely to grant claims by members of pacifist churches, that persons affiliated with other churches are the next most favored group, and that persons not affiliated with any church have the most difficult time having their claims sustained. Rabin, supra note 36 , at $657-58$; Reisner, supra note 7, at 531-35. But cf. Clay v. United States, 403 U.S. 698, 700 (1971) ("[T] he Selective Service System must be concerned with the registrant as an individual, not with its own interpretation of the dogma of the religious sect, if any, to which he may belong.") Registrants are also aided by affirming their belief in a Supreme Being. Reisner, supra at 531. Interestingly enough, the Reisner study indicates that while church affiliation (and particularly affiliation with traditional peace churches) is often controlling, the length of time of affiliation and the regularity of church attendance as reported by the registrant to the draft board seem unimportant. Id. 538.

262 Compare this situation to the dilemma of conscientious objectors when there is no procedure for investigating conscientious objector claims; see text accompanying notes $163-69,185-93$ supra. 
it invariably accepted such claims in the absence of evidence to impeach them, disingenuous registrants would receive conscientious objector exemptions to which they are not entitled. By hypothesis, there is nothing to which the draft board can look that will reliably guide its determination.

To be sure, not all nonaffiliated objectors will lack objective evidence relevant to their sincerity. Some will have manifested their beliefs through action or by making statements indicating opposition to war. It is likely, however, that their lack of religious affiliation will make it more difficult for them than it would be for a church member to show that those actions or statements reflect a belief that substantively qualifies. Opposition to war qualifies one for the exemption only if it is (1) directed to all wars and (2) founded upon moral or religious principle and not just pragmatic considerations. The fact of religious affiliation obviously will assist materially in convincing a board that the basis for opposition is moral or religious. When traditional religion is the foundation of a belief it may also be more easily deemed to extend beyond a particular war to war in general. Nonaffiliated objectors who can point to antiwar actions or statements as evidence of their opposition to war may still run a heavy risk that those actions or statements will be dismissed as merely political or as directed toward a particular war. ${ }^{203}$

Objective evidence is helpful not only in proving that a registrant is sincere in his belief that he should not participate in war; it may also tend to show that the belief is held with the requisite depth-that it "occupies a place in the life of its possessor parallel to that filled by the orthodox belief in God of one who clearly qualifies for the exemption." Here again, objectors lacking traditional religious affiliations may be disadvantaged: ${ }^{264}$ the kind of evidence they have, antiwar statements or activities, for example, may be quite consistent with a merely political belief or one directed only at a particular war. Again, the presence of some objective evidence may be insufficient to provide the board with a firm basis for distinguishing the valid claims from

263 Although a man clearly could consistently oppose the Vietnam conflict and also be entitled to conscientious objector status, Professor Reisner reports that when a file shows opposition to the Vietnam war a registrant's chance of receiving a conscientious objector classification from an appeal board substantially lessens. Reisner, supra note 7, at 530. On the basis of a limited sample he also reports that "[o]pposition to the Vietnam War was only slightly less decisive as a negative factor in the cases that underwent Justice Department review." Id. 541.

204 That traditionally religious objectors will be at an advantage with respect to the depth requirement is clear since the very function of the depth requirement is to define religion-to determine whether a man's opposition to war is the product of "religious training and belief" in the statutory sense. See text accompanying notes 117-25 supra \& notes $123,125$. 
those that are contrived or are legally inadequate under the statutory standard.

Whether a particular registrant holds his belief with the requisite depth may indeed be an even more elusive issue than the question of sincerity. One who has a sincere belief that he should not participate in war may himself be uncertain whether his belief "occupies a place in [his] life . . . parallel to that filled by the orthodox belief in God of one who clearly qualifies for the exemption." 265 If the possessor of a belief in all honesty is unable to determine whether his belief meets the statutory criteria, it is clearly beyond the competence of an outside factfinder to make that determination with accuracy. The board may well resort to deciding the issue of depth according to categories of registrants, rather than assessing the particularized beliefs of individual registrants.

Theoretically, a traditionally religious man might also be found disqualified from conscientious objector status because of lack of depth. He might have a sincere belief that stemmed from religious affiliation that it was wrong for him to participate in war, yet the belief might not be sufficiently important to him or central to his existence to meet the law's requirement. In practice, however, draft boards faced with claimants having traditional religious affiliations and objecting with apparent sincerity to participation in war in any form are apt to presume that the beliefs are held with the requisite depth-to presume it simply because of the impossibility of actually determining whether the depth criterion is satisfied.

Even if investigation of conscientious objector claims were provided, therefore, determinations of conscientious objector status would continue to be unreliable. ${ }^{26}$ In many cases-most frequently, but certainly not exclusively, cases involving nonaffiliated registrants-there would still be no adequate factual basis for deciding whether a registrant satisfied all of the statutory criteria. Whether the lack of an adequate factual basis for decision would ultimately redound to the benefit of the registrant is uncertain. It would not if there were enough in the record to provide a basis in fact for a decision against him on any ground. In that situation, the board could indulge its suspicion of the registrant, or its hostility to him, by simply seizing on that ground. Similarly the registrant would not benefit from the lack of adequate evidence if the board could hold against him by findings on demeanor and have its decision upheld. If, on the other hand, de-

265 Uncertainty might arise either from a registrant's failure to understand what degree of depth is required-that is, what is "the place . . . filled by the orthodox belief in God of [a registrant] who clearly qualifies"-or from a registrant's inability to ascertain the exact degree of his own depth of belief.

266 Investigation would, however, improve the situation. See note 169 supra. 
meanor alone were deemed a legally insufficient basis for denial, and if a registrant is sufficiently resourceful to present a claim believable on its face and of such a nature that investigation yields no evidence contrary to it, the situation is the same as when claims are not investigated: any person who is able to state a claim that is legally sufficient to justify conscientious objector status and who has the temerity to fight an adverse Selective Service determination in court should eventually have his conscientious objector claim sustained whether his claim be truthful or not.

Unless required by necessity, we should be reluctant to employ a standard for conscientious objection that is likely in any substantial percentage of cases to lead to unreliable results. An erroneous disposition of a conscientious objector claim entails harsh consequences. The unfairness to a registrant sentenced to prison because of erroneous classification is obvious. There is also a cost to the nation in prosecuting and imprisoning a man who could perform some beneficial service that does not conflict with his conscience. On the other hand, the attainment of conscientious objector status by men who are insincere in their claims is grossly unfair: the direct result of their erroneous classification is that other men must take their place.

\section{A Proposal for Change}

The public has lost confidence in the administration of the draft. In 1941, at a time (pre-Pearl Harbor) when the public was very divided over the wisdom of having a conscription system, a Gallup Poll showed nevertheless that ninety-three percent of the public believed that the draft had "been handled fairly," and only seven percent thought otherwise. ${ }^{267}$ By 1966, however, only forty-three percent felt that "the way [the draft] works is fair," though "[t]he vast majority of Americans favor[ed] drafting young men for military service." ${ }^{268}$ A presidential commission that in 1967 made recommendations concerning the Selective Service System also came to the conclusion that the draft is unevenly administered. ${ }^{269}$ Subsequent to the 1967 amendments, testi-

267 G. WAMrSLEX, supra note 134 , at 1.

268 Id. 2. For a summary of complaints leveled against the draft in the mid1960 's, together with the Selective Service System's rebuttal, see Hearings on the Administration \& Operation of the Selective Service System Before the Honse Comm. on Armed Services, 89th Cong., 2d Sess. 9985-96 (1966).

269 Marshall Commission Report, supra note 135 . The Commission was appointed in 1966 by President Johnson. See Exec. Order No. 11,289, 31 Fed. Reg. 9265-66 (1966). It was headed by Burke Marshall, a former Deputy Attorney General of the United States, and it came to be known as "the Marshall Commission."

Most of the recommendations the Marshall Commission made concerning the administrative restructuring of the system were not adopted. The congressional debate on reform of the nation's draft laws, which culminated in the Military 
mony before congressional committees suggested that widespread inequities still existed. ${ }^{270}$ One source of dissatisfaction has been the lack of centralization and the extent of discretionary decisionmaking, which have combined to produce a lack of uniformity. ${ }^{271}$ Another is that the system of exemptions and deferments makes it more likely that socially and economically disadvantaged persons who are qualified for service will be drafted, than will members of more privileged groups. ${ }^{272}$ Procedural changes in the way the draft is to operate have been one means adopted by lawmakers to increase the fairness of the system. ${ }^{273}$ Another

Selective Service Act of 1967, 50 U.S.C. APP. $\$ \$ 451-73$ (1970), as amended, 50 U.S.C.A. APP. \$\$451-71a (Supp. 1972), can be found in Hearings on the Admintistration \& Operation of the Selective Service System Before the Honse Comm. on Armed Services, 89th Cong., 2d Sess. (1966) ; Hearings on S. 1432 Before the Senate Comm. on Armed Services, 90th Cong., 1st Sess. (1967) ; Hearings on Extension of the Universal Military Training \& Service Act Before the House Comm. on Armed Services, 90th Cong., 1st Sess. (1967) ; S. REp. No. 209, 90th Cong., 1st Sess. (1967); H.R. REP. No. 346, 90th Cong., 1st Sess. (1967) ; H.R. ReP. No. 267, 90th Cong., 1st Sess. (1967) ; Civilian Advisory Panel on Military Manpower Procurement, 90th Cong., 1st Sess., Report to the House Comar. on Armed Services, (Comm. Print 1967) (the "Clark Report," authored by a panel chaired by General Mark Clark, was appointed by the Armed Services Committee to give Congress a basis for examining the draft independent of the Marshall Commission).

270 Hearings on S. Res. 39 Before the Subcomm. on Administrative Practice \& Procedure of the Senate Comm. on the Judiciary, 91st Cong., 1st Sess. 58-78, 378 (1969); Hearings on Selective Service \& Military Compensation Before the Senate Comm. on Armed Services, 92d Cong., 1st Sess. 120 (statement of Senator Kennedy), 339 (statement of Mr. Caplan) (1971); Hearings on Administration \& Operation of the Draft Law Before the Special Subcomm. on the Draft of the Honse Comm. on Armed Services, 91st Cong., 2d Sess. 12,809 (1970) (statement of Representative Harrington).

271 See, e.g., Hearings on S. Res. 39 Before the Subcomm. on Administrative Practice \& Procedure of the Senate Comm. on the Judiciary, 91st Cong., 1st Sess. 378 (1969) (pronouncement on Selective Service System adopted by the United Church of Christ); Hearings on Selective Service \& Military Compensation Before the Senate Comm. on Armed Services, 92d Cong., 1st Sess. 120 (statement of Senator Kennedy), 339-42 (statement of Mr. Caplan), 400 (statement of Lutheran Church) (1971); Marshall Commission Report, supra note 135, at 17-29, 41-42; J. Davis \& K. Dolbeare, supra note 134, at 198-99, 207.

272 Hearings on Selective Service \& Military Compensation Before the Senate Comm. on Armed Services, 92d Cong., 1st Sess. 388 (1971) (statement of William Keeney); Hearings on Administration \& Operation of the Draft Before the Special Subcomm. on the Draft of the House Armed Services Comm., 91st Cong., 2d Sess. 12,809 (1970) (statement of Representative Harrington); MARSHall CoMmission Report, supra note 135 , at 9-10, 21-26; J. Davis \& K. DolbeARE, supra note 134, at $15-17,129-52$.

273 Although the 1971 amendments enacted some of the procedural changes often called for-statement of reasons for rejecting registrants' claims, presence of quorum of local board at personal appearance, right to appear before classification, and the right to present witnesses-many of the perceived procedural shortcomings have not been remedied. Among these are the nonrepresentative character of the Selective Service boards, the absence of a right to counsel at local board proceedings, the absence of a right to a transcript of local board proceedings, Hearings on Selective Service \& Military Compensation Before the Senate Comm. on Armed Services, 92d Cong., 1st Sess. 425-26 (1971) (statement of Mr. Neier), and the lack of local board awareness regarding the state of the law. Hearings on' $S$. Res. 39 Before the Subcomm. on Administrative Practice \& Procedure of the Senate Comm. on the

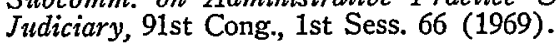


has been to create a truly random system of selection-as the lottery commenced in 1970 is designed to be ${ }^{274}$-among all those equally vulnerable to service and to cut back deferments and exemptions that create privileged groups of persons able to minimize their vulnerability. In contrast to the notion that General Hershey made popular-that the Selective Service System should, through the use of deferments, channel manpower into activities it considers in the national interest ${ }^{275}$ - the current conception is of a system where deferments and exemptions are minimized, the largest possible number of men is eligible to serve, and the choice of who actually shall serve is dictated by chance. ${ }^{276}$

As a result the fatherhood, occupational, and student deferments have been substantially cut back in recent years. ${ }^{277}$ The conscientious objector exemption, however, has remained substantially unchanged, though it is at least equally susceptible to inequity in its administration. It may be that advantaged persons are more likely to be conscientious objectors than are the disadvantaged-at least objectors of the nottraditionally-religious variety recognized in $W e l s h$ and Seeger. At any rate, the sophistication and the ability to hire counsel put one at a great advantage in formulating a sustainable conscientious objector claim and

274 The path for a random selection process was cleared by repeal of $\$ 5$ (a) (2) of the Military Selective Service Act of 1967 which preserved the "oldest first" induction system. Act of Nov. 26, 1969, Pub. L. No. 91-124, §2, 83 Stat. 220. Two days later, President Nixon, pursuant to his rulemaking power, adopted a system of random selection. Proclamation No. 3945, 34 Fed. Reg. 19,017 (1969), 50 U.S.C. APP. $\$ 455$ (1970).

$\mathbf{2 7 5}$ Hearings on the Administration \& Operation of the Selective Service System Before the House Comm. on Armed Services, 89th Cong., 2d Sess. 9620, 9623 (1966) (testimony of General Hershey):

I do not believe we are so rich in human resources that we can afford deliberately to ignore opportunities we have to channel people into training and the application of training. There are enough factors over which we have no control which interferes with the development of the potential of our citizens, and with the best utilization of that potential when it is developed. By deferment we can influence people to train themselves and to use the skills they acquire in work critical to the Nation, in civilian or in military life.

See also 1965 Dir. Sel. Sert. Ann. Rep. 18; Selective Service and Chronology 30 (1965).

276 See, e.g., Hearings on S. Res. 39 Before the Subcomm. on Administrative Practice $\mathcal{E}$ Procedure of the Senate Comm. on the Judiciary, 91st Cong., Ist Sess. 986 (1969) (article by Senator Kennedy in EveNr, June 1969).

277 50 U.S.C.A. Apr. $\$ 456$ (h) (Supp. 1972), amending 50 U.S.C. A.P. $\$ 456$ (h) (1970). Compare Exec. Order No. 11,360, 32 Fed. Reg. 9787, 9791 (1967), with 32 C.F.R. $\$ 1622.25$ (1972) (student deferments). Compare Exec. Order No. 11,360, 32 Fed. Reg. 9787, 9791 (1967) (III-A deferment to any male with child or children and bona fide family relationship), with 32 C.F.R. $\$ 1622.30$ (1972). Compare Exec. Order No. 11,527, 35 Fed. Reg. 6571 (1970), with 32 C.F.R. \$1622.22 (1972) (occupational deferments). 
in having it ultimately sustained. The conscientious objector exemption may, then, be criticized on the ground that the privileged have the easiest access to it - a criticism also leveled at the occupational and student deferments. In addition, its administration is unfair because the inherent difficulties of determining who is a conscientious objector make that classification much more susceptible to false claims than any others.

The problem of inequitable administration would of course be eased if objective criteria were used-if, for example, one were to make membership in particular peace churches the sole test of conscientious objection. ${ }^{278}$ The intractable difficulty is in arriving at objectively provable criteria that include all to whom we wish to extend the exemption without allowing the exemption to be claimed too broadly. Alternatively, the problem of proof in conscientious objector cases could be met by minimizing the attractiveness of the conscientious objector exemption, ${ }^{279}$ thereby decreasing the incentive to make false claims and making more credible those that are made. Our present system, with respect to I-O objectors, is an uneasy compromise: we do burden the objector in return for his avoidance of military service by making him perform alternative service. The burden is largely purposeless, however, because it is not sufficiently great to remove the incentive for false

278 The Draft Act of 1917 followed this approach, at least on paper. It required, as a prerequisite to conscientious objector status, membership in a church whose doctrine forbade participation in war. Selective Draft Act of 1917, ch. 15, $\$ 4,40$ Stat. 76, 78. During that period, the exemption did not permit conscientious objectors to remain civilians. Draftees were deemed members of the military from the date of issuance of their induction order. See M. Sibley \& P. JaCob, Conscription of Conscience 12 (1952).

What conscientious objector exemption there was, however, was not in practice always limited to members of peace churches. Local board treatment of the exemption varied, since the War Department did not prepare a list of recognized peace churches. 1 Selective Service System, Conscientious Objectrón 52 (Special Monograph No. $11,1950)$. But every person who claimed upon induction that he was a conscientious objector, whether or not he was a member of a peace church and whether or not he had been certified as a conscientious objector by his draft board, was segregated from the other soldiers in military camp. See U.S. SeCretary of WAR, Statement ConCerining the Treatment of Conscientious ObJectors in the Army 17 (1919) [hereinafter cited as Statement]; M. Sibley \& P. JACob, supra at 13.

Seven months after the enactment of the Draft Act, the Secretary of War legitimated the practice of treating all objectors alike by issuing an order that not only all religious objectors but also those with "personal scruples against war" should be considered conscientious objectors. STATEMENT, supra at 39. That order was not publicized out of a fear that knowledge of it would encourage persons to make false claims of conscientious objection, id. 17, but in March of 1918 the President confirmed that broadening of the category of conscientious objectors in an executive order. Id. 39-40.

279 Another approach might be to keep the public from knowing how advantageously conscientious objectors are treated in comparison to other persons. This was tried at times during World War I. See, e.g., note 278 stipra. The isolation of the Civilian Public Service Camps where objectors were placed during World War II is also partially explainable on this ground. See M. SuBLEy \& P. JACOB, supra note 278, at $225-26$. 


\section{I-O claims; ${ }^{280}$ the I-O objector (but not the I-A-O objector ${ }^{281}$ ) is much better treated than the ordinary soldier. ${ }^{282}$}

280 To the extent that the burden constitutes work that contributes to the national interest, it can be explained on that ground. In large part, however, it is explicable only as a concession to public opinion, which might be outraged if those refusing military service were not made to perform any service at all.

The government has rationalized the various kinds of alternate service it has provided for in the course of our history on the ground that they both respect the conscientious objector's beliefs and make him contribute in some way to the national interest. The alternate service provisions may be found at Universal Military Training and Service Act, ch. 144, 11 (q), 65 Stat. 86 (1951), as amended, 50 U.S.C.A. APr. $\$ 456(j)$ (Supp. 1972); Selective Training and Service Act of 1940, ch. 720 $\S 5(\mathrm{~g}), 54$ Stat. 889; Selective Draft Act of 1917, ch. 15, §4, 40 Stat. 78. See also Miller, StorIEs From Bretrren LIFe 137-38 (1942), quoted in 1 Selective Service System, Conscientious Objection $42-43$ (Special Monograph No. 11, 1950). In fact, however, it is unlikely that the contribution conscientious objectors' service has made has equalled the costs and effort expended in imposing the requirement on them. During World War I only about 1200 men were furloughed to farms, Statement, stipra note 278, at 25; Stone, The Conscientious Objector, 21 CoLUM. U.Q. 253, 271 (1919) (1300 men), but a great deal of energy at very high levels went into the problem of how to deal with those objectors. See generally Statement, supra. Moreover, a Board of Inquiry consisting of three prominent persons including Harlan Fiske Stone, then Dean of Columbia Law School and later Chief Justice of the United States, spent approximately a year interviewing persons claiming eligibility and passing on the merits of their claims. M. SIBLEY \& P. JACOB, supra note 278 , at 14. The 151 Civilian Public Service Camps that existed to provide alternate service for fewer than 12,000 conscientious objectors during World War II often filled their day with makework. In terms of costs it is most unlikely that the expense of setting them up and administering them was met by work performed. Id. 89, 209, 224-36. But see id. 124-51. Much effort is expended under the current system as well in assigning persons to jobs that qualify for alternate service.

In addition to a lack of returns for the efforts expended, there are other indications that a primary reason for the alternate service scheme is to place some burden on the I-O registrant. See generally Silard, Invalid Dismiption Rules for CO Alternative Service, 3 Colum. Survey of HuMran RIghts LAw 136 (1971). Several Selective Service rules for dealing with I-O's are explainable only on this rationale. Local Board Mem. No. 64, Sec. Serv. L. Rep. 2183 (1962, amended 1968) (rescinded, 5 Sex. SERV. L. REP. 8 (1972)), for example, provided that the registrant's work should be performed outside of the community where he resides and that the position the registrant receives "should constitute a disruption of the registrant's normal way of life somewhat comparable to the disruption of a registrant who is inducted into the Armed Forces." See Local Board Mem. No. 98, SEL. SERv. L. REP. $2200: 7$ (1969) (rescinded, 5 SEL. SERV. L. REP. 8 (1972)). For the current rules, see note 11 supra. Moreover, the alternate service requirement was abolished in the 1948 draft law, Selective Service Act of 1948, ch. 625, $\S 6(\mathrm{j}), 62$ Stat. 612-13, as amended, 50 U.S.C.A. APP. $\S 456(\mathrm{j})$ (Supp. 1972), and was revived in 1951 because of a hostile public reaction to total exemption. See D. Johnson, The Challenge to American Freedors 17 (1963) (illustrating the government's desire to avoid public hostility to overly permissive treatment in formulating World War I legislation); M. SmLEX \& P. JACOB, supra at 239-40 (for an instance of congressional reaction at the end of World War II to what it considered undue favoring of conscientious objectors).

281 See note 284 infra.

282 The I-O objector has no greater likelihood of having to perform alternate service than the I-A registrant has of having to serve. His term of service is no longer than that of the ordinary soldier, and he fulfills it not in the military but in a civilian occupation that typically involves no unusual danger. He participates in choosing his job, and he is treated on equal terms with civilian employees. See text accompanying notes 10-14 stipra \& note 11 .

The burden imposed on I-O objectors as a group, while it may have served the function of placating the public, has never been sufficient to remove the incentive for false I-O claims. The World War II experience with Civilian Public Service Camps probably placed on the objector the heaviest burden this nation has ever imposed. For some persons the hardship of that service was equal to military service. Objectors' 
In keeping with the objective of decreasing the incentive for false conscientious objector claims, it is proposed that conscientious objectors not be exempted from entering the military. Persons who are drafted who have conscientious scruples against killing other persons should, however, be relieved from all obligation to kill. Objectors to killing should be self-selecting; that is, persons should be admitted to this category at their election and without any criteria concerning source of opposition, reason for opposition, depth of opposition, and so forth. ${ }^{283}$

likelihood of service and period of service was comparable to that of the nonobjector, and the danger involved in his work was less. Conscientious objectors, however, were given no compensation for their services. Persons in need of funds, either for themselves or for their dependents, and who could not find an organization to finance them, consequently found alternate service less appealing than military service would have been, and some, because of this factor, abandoned their scruples and entered the military. See M. SibleX \& P. JACOB, supra note 278, at 89-90, 112, 216-24. For persons who could bear the financial burden, however, alternate service remained more attractive than military service. The incentive for false claims remained, therefore, for those who could afford alternate service.

283 The proposed scheme appears in many ways to duplicate that utilized in World War I once it is remembered that the statutory limitation during that period to members of pacifist churches was not in fact observed. See note 278 supra. Even during World War I, however, though personal scruples against fighting were recognized, there were substantive limitations on the exemption. The sincerity of a man's conscientious objection had to be established, see Stone, supra note 280 , at 258,263, and political or selective objection to war was never recognized, STATEMENT, supra note 278, at 32 (public statement issued by Secretary of War); W. KELLOGG, THE CONSCIENTIOUS OBJECTOR 29-30 (1919); Stone, supra at 267.

Not only was the scope of who would qualify for the exemption different in World War I than in the proposed scheme, but also the scope of duties that the conscientious objector had to perform differed. Under the proposal, objectors would be under obligation to perform military duties not related in some direct manner to killing. The World War I statute also provided that no person should be exempt from service in any capacity that the President should declare to be noncombatant. Selective Draft Act of 1917 , ch. $15, \S 4,40$ Stat. 78 . In practice, however, objectors could acquire a broader exemption. Between May 1917, when the Draft Act was enacted, and March 1918, the President did not define noncombatant service. During that period all conscientious objectors were members of the military and were segregated in the military camps. See note 278 supra. Some tried to minimize their identification with the military establishment beyond what noncombatant service would seem to allow, see G. HERstrBERgER, WAR, PEACE, AND NonREsistanCe 128 (1944), and the government did not take a hard line with regard to such objectors. In September 1917, for example, the Secretary of War issued an order that Mennonites not be forced over their objections to wear military uniforms. STATEMENr, supra at 17. (This is not to say, of course, that official policy was invariably adhered to in the camps. See M. SIBLEY \& P. JAcoB, supra note 278, at 15.) When the President finally defined noncombatant service, he limited it to service within the military in the medical, quartermaster, and engineering corps. He also provided, however, that those who would not accept noncombatant service should continue to be segregated and should not be subjected to "punitive hardship" because of their conscientious beliefs. Those persons were subject to courtmartial if their sincerity was questioned; if they were sullen and defiant in attitude; or if they were active in propaganda. Otherwise, their beliefs were respected as long as they kept themselves and their surroundings clean and engaged in regular exercise. STATEMENT, sipra at 18-19.

A few months later the War Department adopted a policy for disposing of the segregated objectors: persons sincerely objecting to noncombatant service could fulfill their military obligation by being furloughed to a farm selected by the government. Any pay they received at the job in excess of that of a private in the military had to be turned over to the civilian branch of the Red Cross. STATEMENT, supra at 19-23; Stone, supra at 258 . Only those who would accept neither a furlough nor noncombatant service were to be court-martialed. 
To avoid the problem of the military not having available enough persons willing to engage in combatant service, conscientious objector service would have to be made equally onerous. If with either type of duty there were an equal chance of serving in combat areas ${ }^{284}$ and conscientious objector service were not in other respects more pleasurable than combatant service, it would seem that a sufficient number of persons would still be available for combat. If events proved otherwise, the conditions of conscientious objector and combatant service would have to be adjusted so that there would be a sufficient number of combatants. $^{285}$ One of many ways that this might be done is to make the term of service for combatants shorter than that for those with objections to fighting. Another is to adjust differences in pay or in fringe benefits; that has the disadvantage, however, of its effectiveness as an

In practice, then, the conscientious objector's options during World War I were much more similar to the system today than appears from the face of the 1917 Draft Act. And World War I is the only period when this country has required conscientious objectors even formally to become members of the military. During the Civil War any person subject to the Draft Law could satisfy his obligation by providing a substitute or paying $\$ 300$ into the War Department to procure a substitute. Draft Act of $1864, \mathrm{ch} .13, \$ \$ 4,5,13$ Stat. 6-7. Special consideration was given to religious objectors who could, if they accepted induction, be assigned to hospitals or to the care of freedmen and, if instead they paid $\$ 300$, could have it applied to the benefit of sick and wounded soldiers. Id. $\$ 17$, at 9 . The only other period of conscription by our national government is from 1940 to the present. At no time during that period has any form of military service been forced on those conscientious objectors who were recognized and whose conscientious objections extended to it. From 1940 to 1946 such objectors were assigned to Civilian Public Service Camps. Selective Training and Service Act of 1940, ch. 720, $\$ 5(\mathrm{~g}), 54$ Stat. 889, as amended, 50 U.S.C.A. APP. $\$ 456$ (j) (Supp. 1972) ; Exec. Order No. 8675, 6 Fed. Reg. 831-32 (1941). Under the 1948 Draft Act no service at all was required of those objectors. Selective Service Act of 1948, ch. 625, $\$ 6(j), 62$ Stat. 612-13, as amended, 50 U.S.C.A. APP. $\$ 456(j)$. (Supp. 1972). In 1951, the current alternative service provision was established-involving individual assignments to civilian jobs rather than public service camps. Universal Military Training and Service Act, ch. 144, §1(q), 65 Stat. 86 (1951), as amended, 50 U.S.C.A. APP. \$456(j) (Supp. 1972).

284 In fact, under the current system a man with a I-A-O classification is likely to be assigned as a medic and is more likely to serve in a combat zone and be exposed to dangerous duties than is a I-A soldier. A. TATum \& J. Tuchinsky, Guide to THE DRAFT 208 (1969). That situation would probably change under the proposed system, however, because of a large increase in the number of noncombatant classifications. The greater danger of I-A-O status today, and the consequent apparent sincerity of an applicant for that status, may be partially responsible for the (presently illegal) practice of some draft boards of automatically granting applications for I-A-O as opposed to I-O status. See Rabin, supra note 36, at 669. See also id. 65152, 670-72. Another likely cause under the quota system was that I-A-O's counted towards a draft board's quota, though I-O's did not. Note 140 supra.

285 While such adjustments may seem awkward and impracticable, they are necessary even under a scheme like the existing one in a total or near-total mobilization situation. Such a calculus was made, for one example, during World War I. At that time, the scope of the conscientious objector exemption was determined only after a preliminary survey of the number of objectors who would be involved. The administration concluded that because the objectors were not numerous "a very generous and considerate mode of treatment" would be possible. D. BEAVER, NEWTON D. BAKER AND THE AMIERICAN WAR EFFORT: 1917-1919, at 232 (1966). It sought to eliminate the problem of the generosity of the exemption attracting false claims first by limiting the exemption to members of peace churches, see Hearings on the Selective Service Act Before the House Comm. on Military Affairs, 65th Cong., 1st Sess. 9 (1917), and later by keeping secret the generosity with which the objectors were treated, see note 278 supra. 
incentive varying with the wealth of the particular draftee. ${ }^{286}$ (Adjustments could be made either by classification-so that the desirability of a particular classification in terms of the danger, discomfort, and/or rewards involved would be the relevant criterion-or they could be made according to the particular assignment that an individual received-in which case all persons who in fact served in a war zone, for example, doing work of equal danger would be treated the same way whether they were classified as combatants or noncombatants.)

The best approach would equalize the burden on conscientious objectors with that on other persons and also have the advantage of not forcing to enter the military many of those objectors with conscientious scruples against entering: Congress could retain alternate service for those opting for it if, at the same time, it increased the likelihood of service for those who chose to perform it in a civilian capacity. Under such a system persons who registered for alternate service might, for example, have to serve automatically, regardless of whether their lottery numbers would make them liable to induction if they were willing to enter the military. Some conscientious objectors to military service, however, would still have to enter. A system of automatic alternate service could operate only for those persons expressing their desire for such service prior to the determination of their lottery number. There would have to be a subsidiary system for persons becoming objectors or registering their objection only after their lottery position showed a likelihood that they would be vulnerable to military service. Such persons would have to enter the miliary but would be able to elect a noncombatant status that was equalized, to avoid false claims, with combatant service. ${ }^{287}$

Under any of these versions of a self-selection proposal some persons who have deep-seated religious beliefs that it is wrong for them to enter the military will be forced either to violate their consciences or be liable to imprisonment; and, under any but the last version, a great many persons may be subject to that dilemma. That is the most apparent objection to adopting a self-selection system. ${ }^{288}$ This Article

280 See note 282 supra \& note 288 infra.

287 Compare this to the situation of the person whose objection is late in crystallizing under the present system, see notes 304-05 infra \& accompanying text.

288 Another objection that might be raised, and that was raised when the House bill prior to the recent statutory amendment provided for a third year of alternate service for I-O objectors, H.R. REP. No. 433, $92 \mathrm{~d}$ Cong., 1st Sess. 21-22 (1971), is that conscientious objectors are discriminated against, in violation of the first amendment free exercise clause and of the fifth amendment due process clause, when they are made to serve for a longer time than other draftees. A similar objection could be voiced if objectors were paid less, or if they were made more likely to serve.

The objection is not fatal to the proposal. If there is a self-selection system for noncombatant service and if persons not compelled by conscience choose noncombatant rather than combatant service, it must be because that service, though more 
will not discuss the question, thoroughly explored elsewhere, ${ }^{289}$ whether the first amendment's guarantee of free exercise of religion requires an exemption from military service for conscientious objectors. While a colorable argument can be made that an exemption is required, ${ }^{290}$ language in Supreme Court opinions has consistently expressed the view that the exemption is an act of legislative grace and that conscientious objectors could constitutionally be subjected to the same military service as other citizens. ${ }^{291}$ Moreover, the Supreme Court has recently

onerous than combatant service in some respects, is altogether not less desirable. Even if there were not a self-selection system, one would have to ask, in determining whether the types of service were equal, whether those not conscientiously compelled to take noncombatant service might be equally content with it. Simply showing a longer period of service would thus not show a discrimination against the conscientious objector.

There might be created, however, such a disparity in the periods of service that the conscientious objector could show discrimination against him. If in a self-selection system the only persons choosing to become noncombatants were those compelled by conscience not to kill, it would seem to indicate that the conditions of noncombatant service in the aggregate were substantially more burdensome than those of combatant service. The fact that persons compelled by conscience continued to sign up for noncombatant service would not show equality because those persons by definition would not be exercising a choice.

Even if conscientious objectors in that situation could show they were being treated more harshly than other persons who serve, they would also have to cross the hurdle of showing that the harsher service was unconstitutional. For the government would doubtless argue that since it could constitutionally require conscientious objectors to enter the military as combatants, see text accompanying notes 289-93 infra, it can constitutionally instead put each objector to a choice between entering as a combatant and performing a harsher form of service. Whether the government would prevail in that argument should depend upon whether the requirement of harsher service is to some extent necessitated by the grant of the privilege not to serve as a combatant (assuming that this is a privilege and not a right). See French, Unconstitutional Conditions: An Analysis, 50 GEo. L.J. 234 (1961).

The only instance from history where a case of discrimination might plausibly be made is in the World War II failure to compensate I-O's serving in Civilian Public Service Camps. See note 281 supra. Failure to pay conscientious objectors is a poor means of equalizing their burden with nonobjectors because the degree of equalization varies with the circumstances of the individual. To the rich objector, alternate service might still seem vastly superior to military service, whereas to the poor man alternate service might be an utter impossibility. The discrimination therefore is limited to the poor conscientious objector; it is not against I-O's in general.

289 See, e.g., R. Drinan, Religion, the Courts, and Public Policy 15-20 (1963) ; W. Katz, Retigion and AMrerican Constirutions 20-21 (1964) ; P. KuRLAND, ReLigion aND THE LAW 37-49 (1962) (discussing cases) ; Brodie \& Southerland, Conscience, the Constitution, and the Supreme Contr: The Riddle of United States v. Seeger, 1966 WIS. L. REv. 306, 319-27; Conklin, Conscientions Objector Provisions: A View in the Light of Torcasco v. Watkins, 51 GEo. L.J. 252 (1963); Donnici, Governmental Encouragement of Religious Ideology: $A$ Study of the Current Conscientions Objector Exemption From Military Service, 13 J. PUB. I. 16 (1964) ; Mansfield, Conscientions Objection-1964 Term, 1965 Rertgron \& Pub. Order 3, 59-81; Note, 34 U. CHI. L. REv. 79 (1966).

290 See, e.g., Brodie \& Southerland, supra note 289, at 319-27; Freeman, Exemptions from Civil Responsibilities, 20 OH1о Sr. L.J. 437, 444-53 (1959). Hochstadt, The Right to Exemption From Military Service of a Conscientious Objector to a Particular War, 3 HARv. Crv. Rights-Crv. LIB. L. Rev. 1, 37-50 (1968) ; Macgill, Selective Conscientious Objection: Divine Will and Legislative Grace, 54 VA. L. Rev. $1355,1389-93$ (1968).

291 See United States v. Macintosh, 283 U.S. 605, 623-24 (1931), overruled on other grounds, Girouard v. United States, 328 U.S. 61 (1946); Hamilton v. Regents, 293 U.S. 245, 266-68 (1934) (Cardozo, J., concurring) ; Selective Draft Law Cases, 245 U.S. 366, 389-90 (1918). Cf. In re Summers, 325 U.S. 561, 572-73 (1945). 
held that under congressional legislation at least two kinds of religious objectors must enter the military, ${ }_{2}^{292}$ and it has found no constitutional problem with the legislation even where the religious objector was not exempt from the obligation of killing. ${ }^{293}$

It seems likely, then, that the constitutionality of the proposal would be sustained. The question still to be faced is whether it is wise to impose the obligation of entering the military on the convinced conscientious objector. The primary case in favor of doing so is that only by that means can a system of conscription relieve all those deeply opposed to killing other persons from a legal obligation to do so. Our current scheme is to allow conscientious objector status to a few and, if their conscientious scruples extend that far, to relieve them fully from military duty. Though the scheme may appear more humane than one obliging conscientious objectors to enter the military, it is not more humane when one considers the price paid for allowing total exemption to the few. In the first place, a system of selection is made necessary and, as discussed above, that system is peculiarly and inevitably unreliable. Members of established peace churches and persons well represented by counsel are particularly favored in the selection scheme. There can be no doubt that valid claims are denied with considerable frequency. Those unfortunate enough to have their claims denied are subject to full military duty, including the duty to kill. But serious as they are, the inaccuracies of the selection process are not the only area of concern. The current test for conscientious objection as well as being difficult of application is also irrational in its limitations. Under present rules, some persons with conceded religious opposition to entering the military are nevertheless put to a choice between entering and imprisonment.

292 Gillette v. United States, 401 U.S. 437 (1971) (the selective conscientious objector) ; Ehlert v. United States, 402 U.S. 99 (1971) (the person whose conscientious objection does not crystallize until after the mailing of his notice to report for induction). The cases are discussed at text accompanying notes 294-306 infra. It is worth noting at this point, however, that while the Court in Gillette confined to selective objectors its holding that requiring service did not violate the free exercise clause, the Court in Ehlert gave some indication that it thought it constitutionally permissible to require all conscientious objectors to perform noncombatant service. The Court said that " $[t]$ he only unconditional right conferred by statute upon conscientious objectors is exemption from combatant training and service," 402 U.S. at 102 (emphasis in original), and that the right to alternate service "arises only if a registrant's "claim is sustained by the local board." Id. at 103 (quoting from the Selective Service statute). Cf. Clark v. Gabriel, 393 U.S. 256, 258 (1968). While the statement is nonsense-since it would indicate that the denial of a I-O classification by a board is unreviewable, which plainly is not the law-the fact that the Court said this was statutory policy and indicated no doubts as to its constitutionality is some evidence of the view it would take were the constitutionality of such a provision actually before it.

293 Although persons like the objector in Ehlert have an opportunity to have their conscientious objector claim sustained before they are assigned to combatant duty, see text accompanying note 306 infra, selective objectors, like those involved in Gillette, can be put to a choice between combatant service and imprisonment. 
In Gillette v. United States, ${ }^{291}$ the Supreme Court held that the Selective Service statute does not grant a conscientious objector exemption to persons whose opposition is to participation in a particular war rather than war in general and that the exemption, as limited, is constitutionally permissible. The Court did not rest its decision that Congress could constitutionally differentiate in its treatment of selective objectors and general objectors on the ground that selective objectors' opposition to participation in war is necessarily less profound or that it is necessarily political and not religious. On the contrary, the Court assumed that the objections of the petitioners in the cases before it were sincere and religious in nature. ${ }^{295}$ One of the petitioners, Gillette, was a humanist. The other, Negre, was traditionally religious; he was a devout Roman Catholic. The Catholic Church is not pacifist but maintains that there are just and unjust wars. While the institution has not taken a position on the justice of the Vietnam conflict, it imposes on each member the duty of reaching his own conclusion whether a particular conflict is just and refraining from participating in those conflicts that are unjust. For a Catholic to participate in a conflict he has concluded is unjust violates his religion in the same way it would for a Quaker to be forced to participate in any war. ${ }^{296}$

The Court held that nevertheless it did not violate the establishment clause for the Selective Service statute to cause disparate treatment of Quakers and Catholics. In the Court's view, the aim of the statute was not to favor one religion over another, and though it had that effect, it was justified by a neutral, secular purpose. ${ }^{297}$ That purpose principally was the government's interest in having a "fair, evenhanded, and uniform" selection process. ${ }^{298}$ It was thought that recognizing selective objection would interfere with this goal because of the difficulties of distinguishing the religious selective objector from one

294401 U.S. 437 (1971).

$295 \mathrm{Id}$. at $440-41,447,458$.

296 See id. at 441. With regard to the Roman Catholic "just war" doctrine, see generally J. RYAN, Modern WAR ANd Basic ErHICs (1933); G. VANN, Morality AND WAR (1939).

297 The Court held also that for the same reason the limitation to universal objectors does not violate the due process clause of the fifth amendment as an arbitrary and capricious enactment. 401 U.S. at 449 n.14. On the same ground it rejected a claim that the statute violated the free exercise clause by requiring religious selective objectors to serve in violation of their religion: a valid and secular governmental purpose justified the burden placed upon the selective objector's exercise of his religion. Id.

298 Id. at 455 . The Court mentioned other secular purposes for the exemption as well-e.g., the recognition that conscientious objectors were unlikely to be effective soldiers and the unwillingness to put conscientious objectors to a choice between their conscience and imprisonment-Id. at $452-53$; but those purposes apply equally to the sincere selective objector. 
whose dissent was merely political. If selective objection were recognized, the Court reasoned

[ $t$ ] here is a danger that as between two would-be objectors, both having the same complaint against a war, that objector would succeed who is more articulate, better educated, or better counseled. There is even a danger of unintended religious discrimination-a danger that a claim's chances of success would be greater the more familiar or salient the claim's connection with conventional religiosity could be made to appear. ${ }^{299}$

Finally the Court thought

[I]t is not unreasonable to suppose that some persons who are not prepared to assert a conscientious objection, and instead accept the hardships and risks of military service, may well agree at all points with the objector, yet conclude, as a matter of conscience, that they are personally bound by the decision of the democratic process. The fear . . . is that exemption of objectors to particular wars would weaken the resolve of those who otherwise would feel themselves bound to serve despite personal cost, uneasiness at the prospect of violence, or even serious moral reservations or policy objections concerning the particular conflict.

... [R] eal dangers . . . might arise if an exemption were made available that in its nature could not be administered fairly and uniformly over the run of relevant fact situations. Should it be thought that those who go to war are chosen unfairly or capriciously, then a mood of bitterness and cynicism might corrode the spirit of public service and the values of willing performance of a citizen's duties that are the very heart of free government. ${ }^{300}$

While these considerations may be true for selective conscientious objection, they are also true of the conscientious objector exemption when selective conscientious objection is not recognized. The Court did not take the view in Seeger that to recognize persons as conscientious objectors who are not religious in the traditional sense would seriously impair the fairness with which the Act is administered because it would become very difficult to distinguish the legitimate conscientious objector from the spurious claimant, ${ }^{301}$ although the argument was as

299 Id. at 457.

300 Id. at $459-60$.

301 See Brief for the United States at 38, 80-82, United States v. Seeger, 380 U.S. 163 (1964).

Similar reasoning caused the Secretary of War to reject the efforts of some to have World War I legislation include nonreligious as well as religious objectors. See D. JoHNson, supra note 280, at 15-17. He said that extending the exemption beyond recognized peace churches would open the way for "self-serving declaration [s]." Hearings on the Selective Service Act Before the Honse Comm. on Military Affairs, 65th 
valid there as in Gillette. ${ }^{302}$ The persons denied conscientious objector exemption in Gillette seem to have objections to entering the military ${ }^{303}$ and participating in war that are, in some cases at least, as strong as

Cong., 1st Sess. 9 (1917). And Senator Phelan arguing against extending the exemption beyond members of peace churches, stated: "If we respect an organization ... that has for a long time, not in contemplation of this war or any other war, conscientiously declared its principles, it would be well for us to do it without opening the doors to every slacker who, without any sincere and long-established convictions might declare also his so-called 'conscientious scruples' in order to avoid service." 55 CONG. REC. 1399 (1917).

302 In fact, it is unlikely that administrative problems concerning the draft would appreciably increase if selective objection were recognized. It is difficult to believe that the Gillette holding will deter many persons who are legally counselled from seeking conscientious objector status, for the line between a selective and a universal objector is not easily defined or proved. The holding instead has made prerequisite to conscientious objector status one more administrative finding where the well-advised and the willing-to-fabricate will be advantaged over the ignorant and the honest.

The objective evidence (if there is any) of many registrants objecting only to particular wars is unlikely to show whether the registrant's opposition is particularized or general. Those registrants, then, who are willing to dissimulate can claim universal rather than selective opposition. In most cases where objective evidence precludes the fabrication, the evidence would also show the registrant disqualified because his opposition is political rather than "religious" in the statutory sense.

The problem of isolating the selective objector is not limited to instances of outright falsehood. Many selective objectors could in good faith characterize their objections as universal, if they were aware of the possibility. When two wars are in progress and a man feels willing to fight in one but not the other, it is clear that his objection is selective. Whenever he objects to all present wars, however, his selectivity is much less clear. Gillette leaves room for an argument that a man should not consider himself disqualified because he thinks he might be willing to fight in some future conflict: "Unwillingness to deny the possibility of a change of mind, in some hypothetical future circumstances, may be no more than humble good sense, casting no doubt on the claimant's present sincerity of belief." 401 U.S. at 448 . The Court said "there is an obvious difference between present sincere objection to all war, and present opposition to participation in a particular conflict only," $i d$., but if one presently objects to all present wars the line is much less clear. Similarly draft manuals counsel that one may claim universal objection though he might have been willing to fight in past wars, see, e.g., A. TATUMr \& J. TuChINSKY, silpra note 284, at 190 (1969); Central Commitree for Conscinntrous Objectors, HandBook For ConSCIENTIOUS OBJECTORS 44-45 (10th ed. 1970), and the case of Sicurella v. United States, 348 U.S. 385 (1955), can be read to support this conclusion. Clearly the degree of certainty a man has as to whether he would or would not have fought in another war is one factor in deciding whether he is a universal objector. But with such uncertain tests of what constitutes selective objection it is difficult to believe the Supreme Court's Gillette hoiding contributed to a "fair, evenhanded, and uniform" selection process.

303 It might be unnecessary, if the current scheme did recognize selective objection, for selective objectors to receive I-O status rather than entering the military and then declining to support or participate in the particular conflict to which they object. Since currently the objector cannot be sure that he will not be used in the conflict to which he objects if he enters the military, it is reasonable for him to object to entering at all. The alternatives would be either to violate his conscientious beliefs, or to enter and obey orders only until he was asked to participate in the conflict to which he objects. At that time he would face court-martial for refusing to obey orders and be subject to the military justice system. His selective objection would not be a defense, just as it is not in the civilian system where he would face prosecution if he refused to enter the military at all. United States v. Noyd, 18 U.S.C.M.A. 483, 40 C.M.R. 195 (1969). See Dep't of Defense Directive No. 1300.6, § VB1, SEI. SERV. L. REP. 2326 (Aug. 20, 1971). For another bar to the objector raising his defense before the military tribunal, see $i d$. \$VB2. See also Negre v. Larsen, 418 F.2d 908 (9th Cir. 1969), aff'd sıb non. Gillette v. United States, 401 U.S. 437 (1971). 
the objections of universal pacifists; yet they must be willing to kill or else face imprisonment.

There is another instance as well in which the Supreme Court has recently held that persons conscientiously opposed to participation in war must enter the military. In Ehlert $v$. United States, the Court decided that one whose conscientious objection crystallizes after the mailing of his notice to report for induction may not raise his conscientious objector status before the Selective Service board or in defense of a criminal prosecution for refusing to submit to induction. ${ }^{304}$ The only way he will be able to raise his conscientious objector claim is by entering the miliary and seeking release as a conscientious objector under military procedures. ${ }^{305}$

304 Although the regulations require reopening of the registrant's classification with its consequent rights to personal appearances and appeal whenever the registrant presents a new prima facie claim of conscientious objection, see notes 33-35 supra \& accompanying text, the rule differs for claims made initially after the mailing of the induction notice. The local board cannot reopen those claims unless it "first specifically finds there has been a change in the registrant's status resulting from circumstances over which the registrant had no control." 37 Fed. Reg. 5123 (1972) (to be codified at 32 C.F.R. $\$ 1625.2$ ). In Ehlert, the Supreme Court was to decide a conflict among the circuits as to whether a registrant becoming a conscientious objector after the mailing of his notice to report for induction (a) necessarily was, (b) might or might not be, or (c) could not be a circumstance beyond the registrant's control (a) requiring, (b) permitting, or (c) not allowing the board to reopen. The issue was of some moment for, while a claim maturing at that late date might be sincere and otherwise entitled to recognition, the tool for delay that ability to force reopening always gives the registrant, see note 34 supra, might be particularly susceptible to misuse and particularly destructive of orderly induction procedures if it were available after the mailing of a notice to report.

The Court's opinion does not make absolutely clear which of the three holdings as to the application of the regulation it adopted. Mr. Justice Stewart's opinion for the Court begins with the statement: "The question in this case is whether a Selective Service local board must reopen the classification of a registrant" for a postinduction notice claim, 402 U.S. at 100 (emphasis added), whereas the body of the opinion speaks as though the issue is whether the board is permitted to reopen. See, e.g., the closing sentence, which states: "IW]e hold that the Court of Appeals did not misconstrue the Selective Service regulation in holding that it barred presentation to the local board of a claim that allegedly arose between mailing of a notice of induction and the scheduled induction date." Id. at 107-08 (emphasis added). The Court's reasoning best accords with the second quoted sentence and with the view that the Court has concluded that a board may not reopen such a claim. It accepted the government's interpretation of the regulatory language that the "circumstances" beyond a registrant's control had to be "objectively identifiable" and "extraneous"-such as injury to the registrant which made him eligible for a physical deferment. $I d$. at 104-05.

It might still be argued by a late-crystallizing conscientious objector whose change of heart was prompted by such an "objectively identifiable" circumstance that he falls within the group whose late claim can be heard, but late conscientious objector claims as a general class will not qualify for late reopening. The Senate, apparently not content with the holding of Ehlert, sought a provision in the 1971 amendments prohibiting induction of conscientious objectors whose claims arise after receipt of an induction notice. The House conferees, however, were adamant in their opposition to this proposal. The Senate receded "with the understanding that in unusual cases, local boards would have the discretionary authority of extending to such registrants a hearing on their late claim if the circumstances so warranted." H.R. REP. No. 433, $92 \mathrm{~d}$ Cong., 1st Sess. 22 (1971).

305 The result in Ehlert was dependent on the Court's conclusion that it did "not leave a 'no man's land' time period in which a claim then arising could not be presented in any forum." 402 U.S. at 102 . The registrant whose claim was late in 
The plight of the conscientious objector whose objection was late in crystallizing is obviously less severe than that of the selective objector in that he need enter the military only for purposes of seeking release. During the time he is seeking release he is not to be assigned to duties in conflict with his conscience, ${ }^{300}$ and he will be faced with the prospect of total military service only if his claim of conscientious objection is denied. Nevertheless it is an instance where a person whose conscience and/or religion forbids him to enter the military at all-not merely to refrain from combat-is forced either to face imprisonment or to enter the military in violation of his conscience.

Under the proposed self-selection system, selective conscientious objectors, late objectors, and others who, for one reason or another, would not presently qualify for alternate or noncombatant service could be relieved from the duty of killing other human beings if they elected to perform, instead, whatever noncombatant service was available to objectors. (Under the increased-likelihood-of-service variant, preserving alternate service, some of these persons could also qualify for alternate service, but those who filed their claim after their lottery number was determined would be required to enter the military.) A basic supposition underlying this proposal is that the most compelling reason for a person to seek exemption from military service is that he has conscientious scruples against taking human life and that it is therefore

arising could present it to military authorities after induction. If a man does not enter the military, however, either because his principles forbid it or because he is ignorant that entry is the only avenue for further pursuit of his claim, he has no forum and no defense to criminal prosecution. The result is harsh for such a registrant, once one admits, as the Court does, $i d$. at 104 , that the registrant's conscientious objection may be sincere.

The result could have been avoided without giving the registrant power to cause any great delay in his induction. The Court could have held that a draft board should pass, on a case-by-case basis, on whether there has been a change in status resulting from circumstances beyond the registrant's control, see note 304 supra, and that a proper component in this inquiry is whether the registrant is sincere in his claim. The decision on whether the registrant qualifies for reopening then would incorporate a decision on the merits. If the registrant were found insincere, his case would not be reopened and he would not gain rights to personal appearances and an appeal. He would, however, have had an opportunity to convince his local board. More important, if he then refused induction, he could raise any local board error in denying his conscientious objector claim as a defense to his criminal prosecution. The Second Circuit prior to the Ehlert decision adopted such a solution. See Paszel v. Laird, 426 F.2d 1169 (2d Cir. 1970).

A simpler method of preserving a criminal defense for the registrant who refuses induction, and a method that involves no delay whatsoever in the induction procedures, would be to allow a registrant whose objection crystallized late, once he has refused induction and is to be criminally prosecuted, to have a hearing before his local board on whether he did become a sincere conscientious objector and to have the board's conclusion reviewable by a court, according to the usual basis-in-fact standard of review, in defense to the criminal prosecution. If registrants with late conscientious objector claims do, however, lose all forums by refusing induction, there should at least be some assurance that when faced with the choice whether to submit they be meaningfully advised of the consequences of the decision.

306 Dep't of Defense Directive No. 1300.6, §VIF, SEL. SERv. L. REP. 2330 (Aug. 20, 1971). 
more important for society to grant that exemption to all persons sincerely seeking it than it is to respect the beliefs of persons who feel it is wrong for them to enter the military at all. ${ }^{307}$ To force a person to do an act that is forbidden by his religion may possibly be a more serious impingement on his freedom than to forbid him to do an act that his religion requires. ${ }^{308}$ More important, when the required act is one that society itself regards as abhorrent in most circumstances, there is particularly persuasive reason for honoring the individual's decision that he cannot in good conscience comply.

A person may, of course, believe that it is wrong to enter the military just as strongly as others believe that it is wrong to kill, and society's toleration of diverse religious philosophies should not generally depend upon whether a religion's views are understandable or acceptable to society as a whole. ${ }^{309}$ Nevertheless it does seem proper, or at least permissible, for society, when it is exempting a group from a generally-imposed obligation, to make a judgment that an aversion to killing is of a different order in the scale of values than an aversion to doing other things-for example, entering the military, wearing a uniform, bearing arms ${ }^{310}$ and to give recognition to that objection while refusing to recognize other objections that it views as less compelling. ${ }^{311}$

307 Indeed, it is either expressly stated or implicitly assumed by those who contend that the conscientious objector exemption is constitutionally required that the source of the requirement is the fact that in the military one may be forced to kill, an act normally vigorously frowned upon by society.

308 This argument is made in Stone, supra note 280, at 268; Clark, Guidelines for the Free Exercise Clause, 83 HARv. L. Rev. 327, 345-46 (1969); Macgill, supra note 290 , at $1390-91$ (1968).

309 Cf. United States v. Seeger, 380 U.S. 163, 184-85:

The validity of what [an applicant for conscientious objector status] believes cannot be questioned. . . [Such an inquiry is] foreclosed to Government. As Mr. Justice Douglas stated in United States v. Ballard, 322 U.S. 78, 86 (1944): "Men may believe what they cannot prove. They may not be put to the proof of their religious doctrines or beliefs. Religious experiences which are as real as life to some may be incomprehensible to others." Local boards and courts in this sense are not free to reject beliefs because they consider them "incomprehensible." Their task is to decide whether the beliefs professed by a registrant are sincerely held and whether they are, in his own scheme of things, religious.

$310 \mathrm{~A}$ case can be made that those who limit themselves to alternate service are more principled than those willing to engage in noncombatant service because they refuse not only to participate directly in killing but also to be any part of a system that has that as its aim. The rationale, however, would carry over to nonpayment of any taxes to support the war, and perhaps even to nonpayment of any taxes to a government that engages in war. Moreover, in anything short of a total mobilization situation, a conscientious objector who declines to serve at all in the armed forces does not thereby reduce the number of persons who will serve or the number of lives that will be taken. He simply withdraws himself from the system so that another person must take his place. If one focuses on those facts, the I-A-O's role appears at least as principled as the I-O's.

311 Conscientious opposition to governmental obligations other than military ones by the same token is not by any means generally honored. See, e.g., Cantwell v. Connecticut, 310 U.S. 296, 303-04 (1940); Jacobson v. Massachusetts, 197 U.S. 11, 29 (1905) ; cf. Cleveland v. United States, 329 U.S. 14, 20 (1946). 
Even under the current scheme of conscientious objection where we have satisfied groups like the Quakers by allowing them the option of alternative service, we make discriminating judgments about the importance of various religious objections concerning war and we honor some more than we do others. Jehovah's Witnesses have long taken the position that performing alternative service, as well as entering the military, is in violation of their conscientious beliefs. ${ }^{312}$ Their religious objection has not been recognized, and they have been put to the choice of violating their convictions in this respect or facing imprisonment. ${ }^{313}$ Others have found it contrary to their conscience to register for the draft, ${ }^{314}$ or to pay taxes to support the war, ${ }^{315}$ but Congress has not honored their objections even when they are as sincere and as deeply felt as interests that are respected. The precise line which has been drawn in the past was influenced by political forces, ${ }^{316}$ and doubtless such forces shall continue to shape the policy for the future. But if principle were to govern, it would seem that the interests now recognized as sufficient to justify the grant of permission to perform alternative service in lieu of noncombatant service-that it violates a man's conscience to be any part of a system that attains its objectives by destroying human beings; that the conscientious objector cannot wear a uniform because he believes it indicates approval of military

312 See Tietz, Jehovah's Witnesses: Conscientions Objectors, 28 S. CAL. L. Rev. 123,130 (1955). The religion's official doctrine is that each individual Witness should interpret for himself what implications Witness doctrine has for his action. M. Sibley \& P. JACOB, supra note 278 , at 35 . In practice, however, it is expected that a Jehovah's Witness will not accept alternate service. Id.

313 During the 1940's and the 1950's from 80 to $90 \%$ of all conscientious objectors involved in criminal prosecutions were Jehovah's Witnesses. See Smith \& Bell, supra note 147, at 711, 714.

314 Cf. McGee v. United States, 402 U.S. 479 (1971).

315 See, e.g., Joan Baez' refusal to pay income taxes, reported in N.Y. Times, Apr. 16, 1965, at 35, col. 2. The government ultimately, but without her cooperation, recovered the money due from her. N.Y. Times, Mar. 6, 1966, at 72, cols. 1-2. Compare the Dunkards' religiously-based refusal during the Indian Wars either to render military service or to pay a commutation fee, and the government's subsequent extraction of the fee, described in 1 Selective Service Systed, Conscientious OBJECTION 32 (Special Monograph No. 11, 1950).

316 During the period when the World War I exemption was being formulated, the Quakers, the Mennonites, and the American Union Against Militarism (a precursor of the American Civil Liberties Union) were active in working for an exemption. The provision that finally emerged was influenced by the fact that the peace churches' principal concern was an exemption for themselves, see, e.g., G. HershbERger, supra note 283, at 114-19, and the American Union Against Militarism's attempts to win recognition for all religious objectors was undermined by their efforts on behalf of political objectors as well. See D. JoHNson, supra note 280, at 14-18. The political maneuvers leading up to the World War II conscientious objector provisions are described in M. SIRLEY \& P. JACOB, supra note 278, at 45-52. During that period the peace churches and the ACLU did originally push for an exemption for absolutists and for nonreligious objectors as well as for the categories ultimately exempted, but they failed in that endeavor. See NATIONAL Service Board for Religious Objectors, Congress Looks at the Conscrentious OBJECTOR (1943). 
objectives; that it is wrong to minister to an injured military man since that will enable him to resume his destructive duties sooner ${ }^{317}$-are more akin to the interest in not paying war taxes, or the Jehovah's Witness' objection to performing even alternative service, than they are to the conscientious objector's conceived duty not to kill. ${ }^{318}$

The virtues of the present proposal are that it would recognize the most compelling interest in avoiding combatant service and that it could operate far less capriciously than the present system of selecting objectors and granting them privileged status, by granting exemption from combatant service to all who profess conscientious objection to taking life and by requiring them to perform noncombatant service of comparable risks and burdens.

317 These are the arguments that the manuals for draft registrants most commonly suggest using in support of the position that a man's conscientious objection will not permit him to serve in a noncombatant capacity. See, e.g., Central Committee for Conscientious Objectors, Handbook for Consclentious Objectors 41 (10th ed. 1970).

318 Along with their lobbying, see note 316 supra, another probable reason for recognition of the interests of groups like the Quakers is their respectability. See 1 Selective Service System, Conscientious ObJection 42 (Special Monograph No. 11, 1950); United States v. Schwimmer, 279 U.S. 644, 655 (1929) (Holmes, J., dissenting). Adopting a system that would require us to imprison a substantial. number of Quakers might not sit well with the American people. Yet imprisoning Jehovah's Witnesses for observing their religious beliefs creates little stir. The proposed system would put Quakers and Jehovah's Witnesses alike, together with nonreligious persons holding the same beliefs, to a choice between observing their beliefs and facing imprisonment or performing noncombatant service. The imprisonment of many persons presently allowed to perform alternate service might well result. On the other hand, once the unavailability of the alternate service route became established, a number of persons from peace churches whose members now regularly receive a I-O exemption might well enter the military. The World War I experience provides some basis for this prediction. While some persons followed their faith in refusing noncombatant service even when it was not clear that such a refusal would go unpunished, see note 283 supra, a great many persons chose to serve in a combatant capacity contrary to the tenets of their faith. The segregation of conscientious objectors in the military camps led more than $80 \%$ of the more than 20,000 persons inducted who had received certificates from their draft boards that they were entitled to noncombatant status as members of peace churches to abandon their exemption from noncombatant service. STATEMENT, supra note 278, at 16. Similarly, the World War II objectors who renounced the Civilian Public Service Camps because they needed to be compensated for their work, while fewer in number, illustrate the obvious proposition that not all objectors are beyond being influenced by the legal provisions as to whether they must enter the military and by the rewards or penalties attached thereto. 